(1I) Nordic Council of Ministers

\title{
NORDIC COASTAL FISHERIES AND COMMUNITIES
}

Status and future prospects

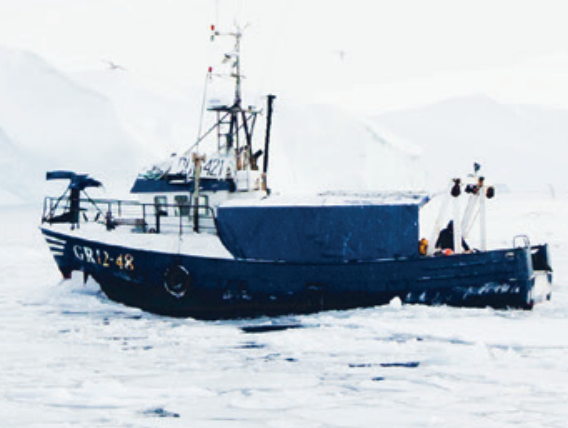





\section{Nordic coastal fisheries and communities}

Status and future prospects

Jónas R. Viðarsson, Marvin Ingi Einarsson, Sigurđur Örn Ragnarsson, Unn Laksá, Rannvá Danielsen, Audun Iversen, Edgar Henriksen, Tønnes Berthelsen, Heather Manuel, Tom Brown, David Decker, Henrik S. Lund, Bengt Larson and Carl-Axel Ottosson

TemaNord 2018:507 


\section{Nordic coastal fisheries and communities}

Status and future prospects

Jónas R. Viðarsson, Marvin Ingi Einarsson, Sigurđur Örn Ragnarsson, Unn Laksá, Rannvá Danielsen, Audun Iversen, Edgar Henriksen, Tønnes Berthelsen, Heather Manuel, Tom Brown, David Decker, Henrik S. Lund, Bengt Larson and Carl-Axel Ottosson

ISBN 978-92-893-5376-2 (PRINT)

ISBN 978-92-893-5377-9 (PDF)

ISBN 978-92-893-5378-6 (EPUB)

http://dx.doi.org/10.6027/TN2018-507

TemaNord 2018:507

ISSN $0908-6692$

Standard: PDF/UA-1

ISO 14289-1

(c) Nordic Council of Ministers 2018

Cover photo: Benjamin Hardman - Visit Greenland

Print: Rosendahls

Printed in Denmark

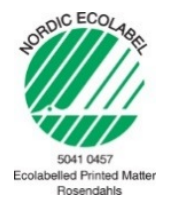

Disclaimer

This publication was funded by the Nordic Council of Ministers. However, the content does not necessarily reflect the Nordic Council of Ministers' views, opinions, attitudes or recommendations.

\section{Rights and permissions}

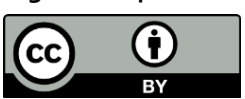

This work is made available under the Creative Commons Attribution 4.0 International license (CC BY 4.0) https://creativecommons.org/licenses/by/4.0

Translations: If you translate this work, please include the following disclaimer: This translation was not produced by the Nordic Council of Ministers and should not be construed as official. The Nordic Council of Ministers cannot be held responsible for the translation or any errors in it.

Adaptations: If you adapt this work, please include the following disclaimer along with the attribution: This is an adaptation of an original work by the Nordic Council of Ministers. Responsibility for the views and opinions expressed in the adaptation rests solely with its author(s). The views and opinions in this adaptation have not been approved by the Nordic Council of Ministers. 
Third-party content: The Nordic Council of Ministers does not necessarily own every single part of this work. The Nordic Council of Ministers cannot, therefore, guarantee that the reuse of third-party content does not infringe the copyright of the third party. If you wish to reuse any third-party content, you bear the risks associated with any such rights violations. You are responsible for determining whether there is a need to obtain permission for the use of third-party content, and if so, for obtaining the relevant permission from the copyright holder. Examples of third-party content may include, but are not limited to, tables, figures or images.

Photo rights (further permission required for reuse):

Any queries regarding rights and licences should be addressed to:

Nordic Council of Ministers/Publication Unit

Ved Stranden 18

DK-1061 Copenhagen K

Denmark

Phone +4533960200

pub@norden.org

\section{Nordic co-operation}

Nordic co-operation is one of the world's most extensive forms of regional collaboration, involving Denmark, Finland, Iceland, Norway, Sweden, and the Faroe Islands, Greenland and Åland.

Nordic co-operation has firm traditions in politics, economics and culture and plays an important role in European and international forums. The Nordic community strives for a strong Nordic Region in a strong Europe.

Nordic co-operation promotes regional interests and values in a global world. The values shared by the Nordic countries help make the region one of the most innovative and competitive in the world.

The Nordic Council of Ministers

Nordens Hus

Ved Stranden 18

DK-1061 Copenhagen K, Denmark

Tel.: +4533960200 www.norden.org

Download Nordic publications at www.norden.org/nordpub 



\section{Contents}

Summary

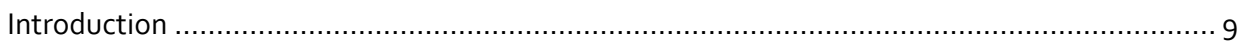

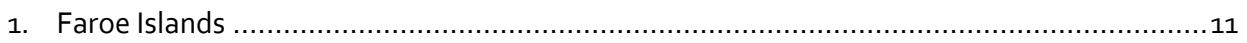

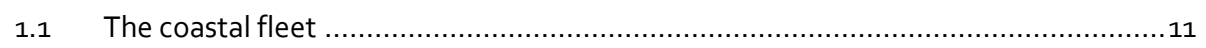

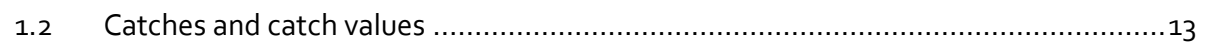

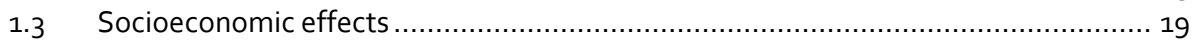

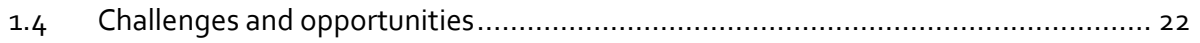

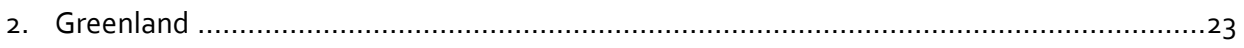

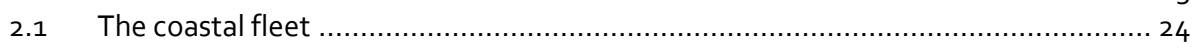

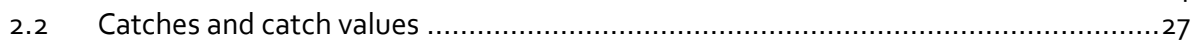

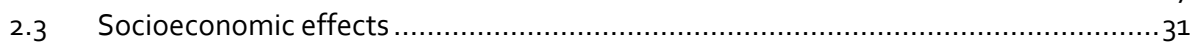

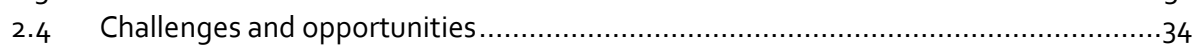

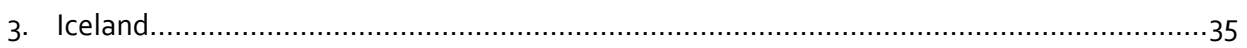

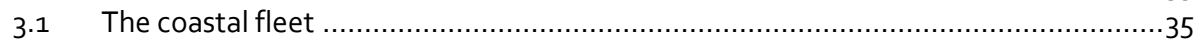

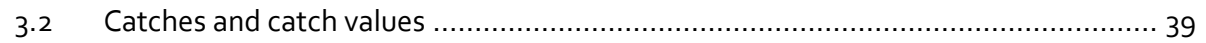

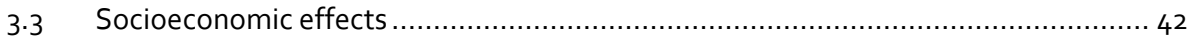

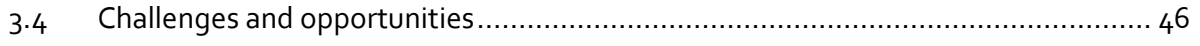

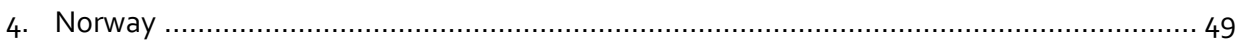

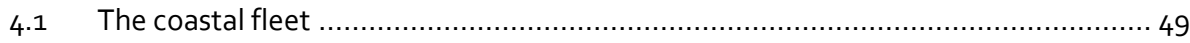

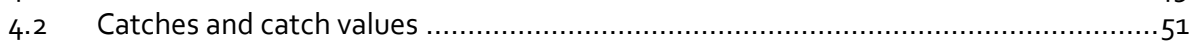

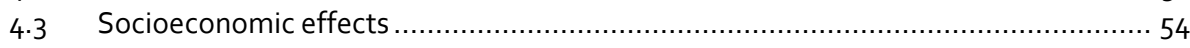

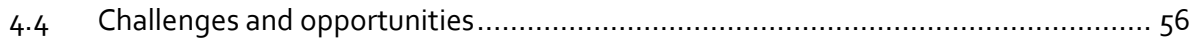

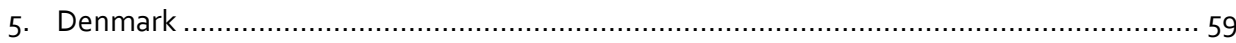

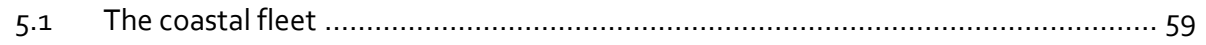

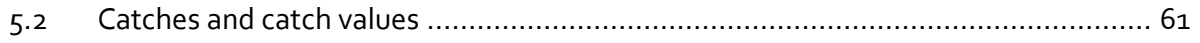

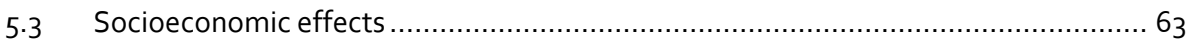

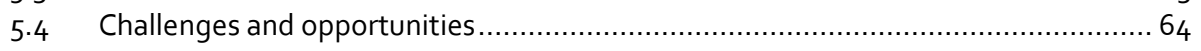

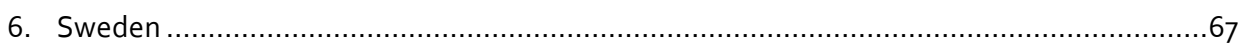

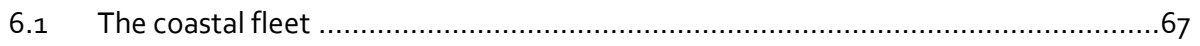

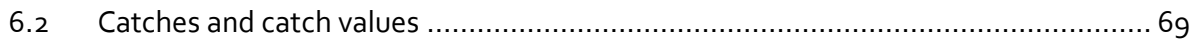

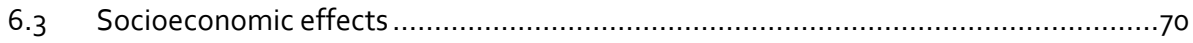

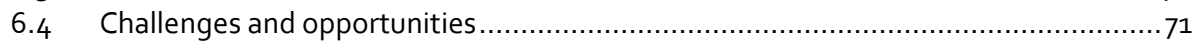

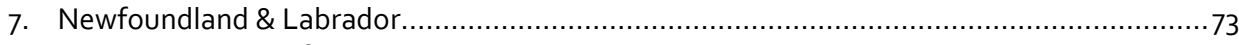

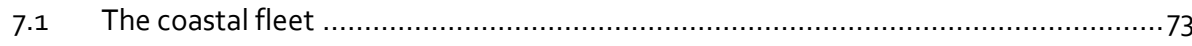

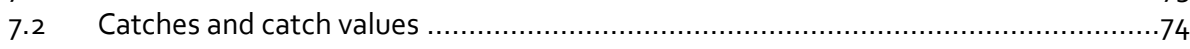

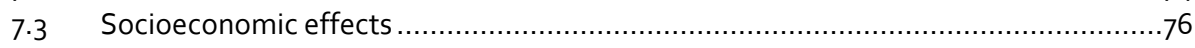

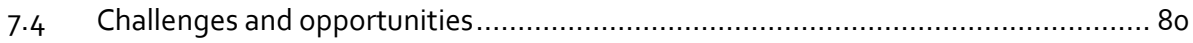

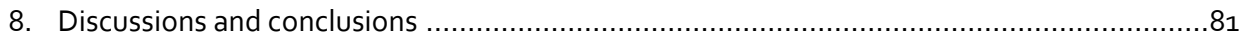

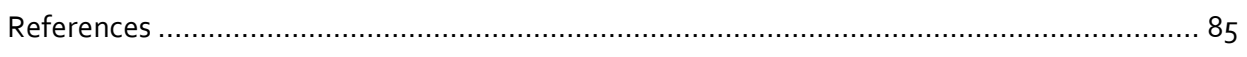

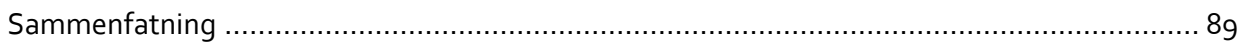





\section{Summary}

Coastal fisheries play a vital role in the marine sector of the Nordic countries and often serves as a backbone of the economy of smaller coastal communities. The coastal fleets usually have a big presence in smaller, more remote fishing villages, supplying local processing companies with raw material. The coastal sector is therefore highly important for regional development, as it represents a significant part of total landings and offers employment for a large number of fishermen, processors and other supporting industries. Urbanization and rapid technical developments in the fishing sector over the last few decades have however resulted in many coastal communities having to fight for their survival. While the coastal fishing sector is generally struggling to return profits, there are as well other challenges that coastal communities are faced with; such as different social structures, educational- and job opportunities and requirements towards a certain "quality of life" that are causing people to migrate from coastal communities to larger cities.

This report reviews the coastal sectors in seven Nordic countries (Faroe Islands, Greenland, Iceland, Norway, Denmark, Sweden and Newfoundland), which include almost 20 thousand coastal vessels that are catching close to goo thousand tonnes a year, valued at EUR 1.2 billion. The fleets are though highly variable, ranging from very basic traditional dinghies catching few kilos of fish each year to highly technical industrial vessels with annual catches exceeding 1,000 tonnes. The individual countries do as well have to deal with different challenges; and do each have their unique strengths, weaknesses, opportunities and threats, which are discussed in the report. 



\section{Introduction}

Coastal fisheries play a vital role in the marine sector of Nordic countries and often serve as a backbone of the economy of smaller coastal communities. The coastal fleets usually have a big presence in smaller, more remote fishing villages, supplying local processing companies with raw material. The coastal sector is therefore highly important for regional development in Nordic countries, as it represents a significant part of total landing and offers employment for a large number of fishermen, processors and other supporting industries. Urbanization and rapid technical developments in the fishing sector over the last few decades have however resulted in many coastal communities having to fight for their survival. While the coastal fishing sector is generally struggling to return profits, different social structures, educational opportunities and requirements towards a certain "quality of life" are causing people to migrate from coastal communities to larger cities (Heleniak, 2014).

The urbanization seen in the last decade is limiting the renewal of workforce in coastal communities, including in the coastal fishing industry, further adding on to other challenges relating to the sector, such as variability in the quality of coastal catches and reliability in small vessels that are highly weather-dependant. Furthermore, the fierce competition between different fleet types in each of the respective countries, as they compete for the same scarce resource, is creating tension and disunity within the catching sectors. Survival of coastal communities in the $\mathrm{N}$ Atlantic and Nordic countries has therefore, to a large extent, become a political issue, rather than just a question of good or bad business. These recent developments underline that social, economic and environmental considerations need to be addressed when looking at the future of coastal fisheries and coastal communities in the Nordic countries.

The objective of this report is to analyse the status, main challenges and future prospects of the Nordic coastal fleets and the coastal communities. The fleet structure, demographics, catch statistics, landing values, profitability, relevant value chains, socio-economic importance and the importance of the coastal sector on regional development are analysed in the report. Finally, the main strengths, weaknesses, opportunities and threats of the coastal sector and coastal communities is discussed; in order to cast a light on the main challenges that Nordic coastal communities are facing and to explore future opportunities.

The exact definition of a coastal vessel varies between countries and occasionally within a country, but generally refers to smaller sized vessels that utilize a number of different gear types close to shore. The definition in each country usually refers to the boat size, type of fishing gear, fishing grounds or length of fishing trips, but despite considerable efforts by FAO and other stakeholder groups, the international community has not been able to agree upon a common definition. For the purpose of 
this report, the researchers in each country have defined coastal vessels based on national legislations and data availability (Table 1). These definitions do not necessarily reflect the country's official definition of coastal vessels but are set in this report in order to enable comparison between countries. For example, in the case of Norway, boats up to 27.99 meters are considered coastal vessels, but only those below 21 meters are defined as such in this report for consistency.

Table 1: The definitions used for coastal vessels in each of the subject countries

\begin{tabular}{ll} 
Country & Definition constrains \\
Faroe Islands & Vessels $<15$ meters in length \\
Greenland & Vessels licensed to fish within 3 NM from baseline, max 120 GT \\
Iceland & Vessels $<15$ meters in length and 30 GT in size \\
Norway & Vessels $<21$ meters in length \\
Denmark & Vessels $<17$ meters in length (new scheme for $<15$ meters) \\
Sweden & Vessels $<12$ meters in length \\
NL & Vessels $<19.8$ meters (65 ft.) in length \\
\hline
\end{tabular}

Each definition has in addition a number of sub-categories, which are addressed in the relevant chapters of this report.

The report is broken into eight chapters, where the coastal sectors in Faroe Islands, Greenland, Iceland, Norway, Denmark, Sweden and Newfoundland are discussed separately, followed by a discussion chapter where the main highlights from the previous chapters are expanded on. 


\section{Faroe Islands}

The Faroe Islands inhabit around 50 thousand people (Hagstova Føroya, 2017a). The national economy is highly dependent on fisheries and aquaculture. Capture fisheries and aquaculture accounted for $96 \%$ of total exports in 2016, where pelagic species accounted for $43 \%$ and demersal species for $7.5 \%$ (Hagstova Føroya, 2017b). Around $43 \%$ of fish exports were frozen and $33 \%$ fresh chilled (Hagstova Føroya, 2017c). Fisheries and aquaculture accounted for $15 \%$ of the GDP in $2013 .{ }^{1}$ The coastal fishery is however not very important to the economy, especially compared to aquaculture and the pelagic fishery. The export value of aquaculture products increased by almost 500\% from 1993 to 2015 and the pelagic fishery has become very profitable in recent years, with the landings value going from EUR 23 million in 2000 to EUR 56 million in 2015 (Vørn, 2017). This has left the economic contribution of the coastal fleet rather insignificant.

\subsection{The coastal fleet}

Faroese fisheries are managed according to the Commercial Fisheries Act 1994, which divides the Faroese fleet into five vessel groups, of which groups 4 and 5 cover large and small coastal vessels respectively. Group 5 is further divided into commercial and recreational vessels, as shown in Figure 1 (Føroya Skipaskráseting, 2016). A vessel is classified as commercial when it has an annual landing value of more than DKK 400,000 or 54,000 EUR. The Faroese demersal fisheries are managed with effort quotas (fishing days) (í Jákupsstovu, Cruz, Maguire, \& Reinert, 2007), (Løkkegaard, Andersen, Boje, Frost, \& Hovgård, 2004). Commercially operated vessels receive individual effort quotas while recreational vessels utilize fishing days from a common pool of fishing days. Figure 1 shows an example of small coastal vessel operated in the Faroe Islands.

${ }^{1}$ Newest available data 


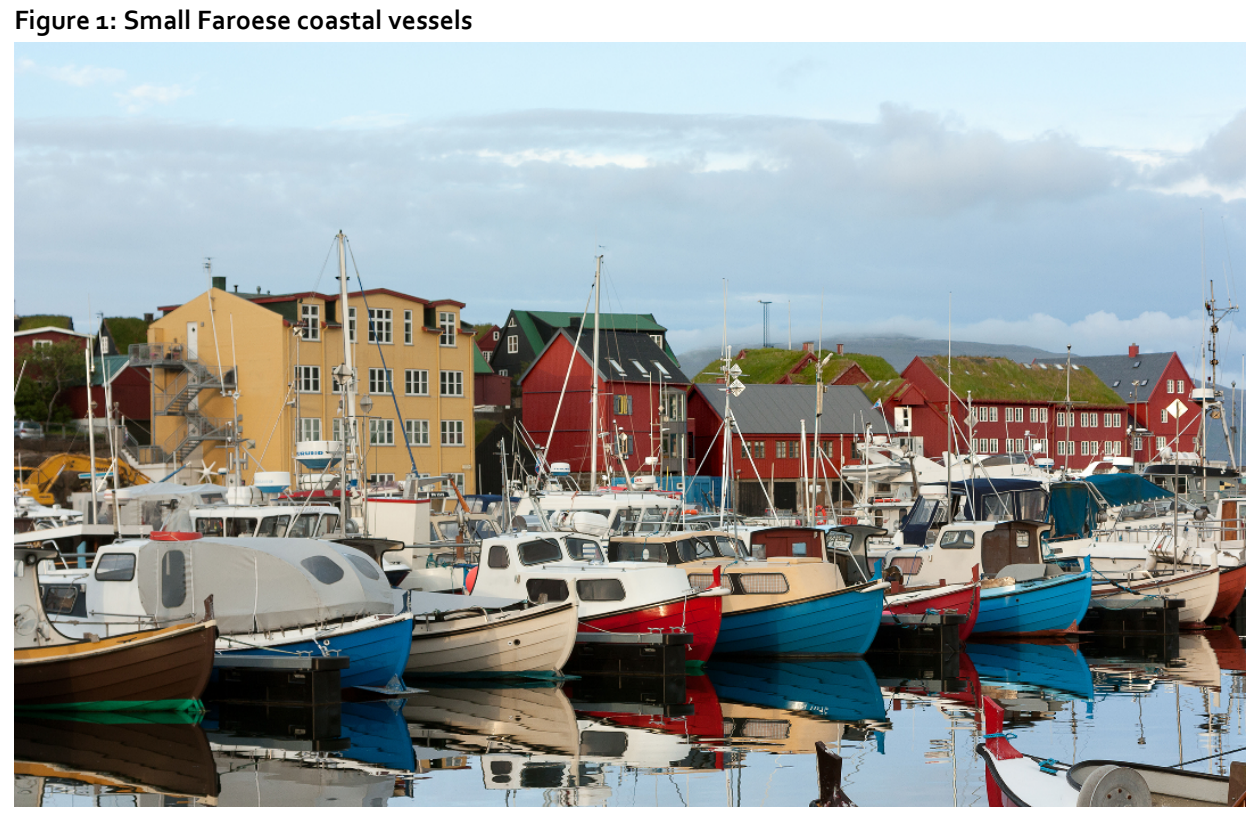

Source: Shutterstock / Matís / steinarba.

Table 2: Coastal vessels in the Faroe Islands, 2016

\begin{tabular}{llrr} 
Vessel group & Description of vessel/fishery & Size & Number \\
& & & \\
4A & Large coastal vessel & $15-40 \mathrm{GT}$ & \\
5A & Small coastal vessel, commercial & $<15 \mathrm{GT}$ & 24 \\
5B & Small coastal vessel, recreational & $<15 \mathrm{GT}$ & 384 \\
Other & Lobster or temporary license & & 10 \\
Sum & & & 426 \\
\hline
\end{tabular}

A total of 426 coastal vessels were registered with the Faroese maritime authority in 2016: 8 large coastal vessels, 24 small coastal vessels, 384 recreational coastal vessels and 10 vessels that only had a lobster license or a temporary license for e.g., mackerel (Føroya Skipaskráseting, 2016). The data indicates that only 36 vessels or $8.5 \%$ are operated commercially. However, several vessels in vessel group ${ }_{5} \mathrm{~B}$ are indeed fully operated, even if their landings value do not exceed DKK 400,000 (Danielsen, 2014). Not all vessels with a fishing licence are active, e.g. 384 vessels were registered in vessel group $5 \mathrm{~B}$ for the year 2016 while only 293 reported catches in 2015, as shown on Figure 2 (Vørn, 2017). 
Figure 2: Vessels reporting catches in the Faroes Islands 2001-2015

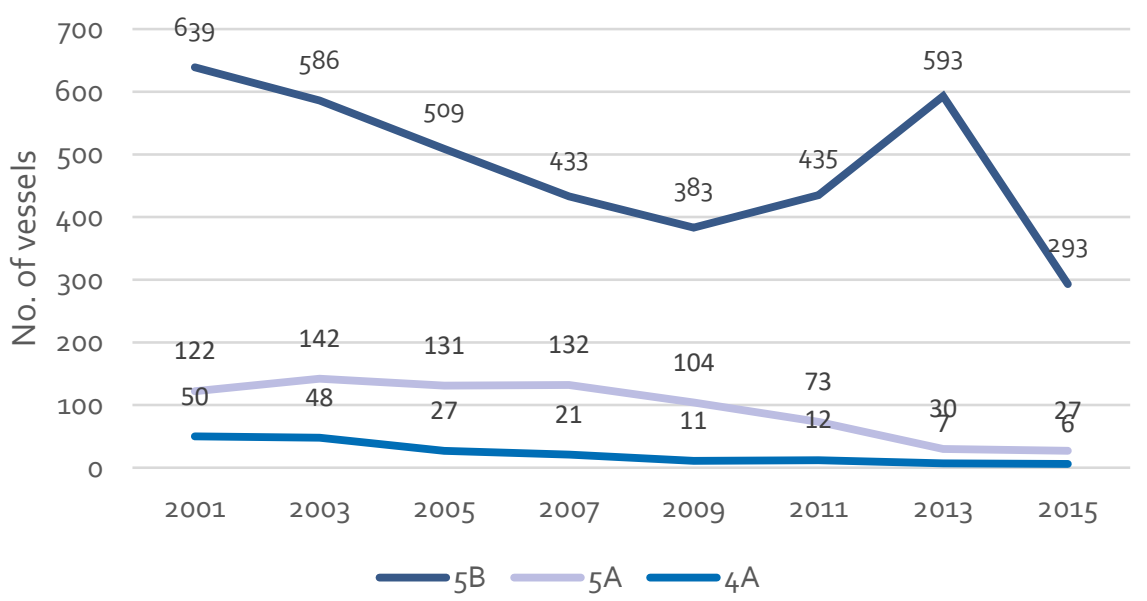

The size of the commercial ( $4 \mathrm{~A}$ and $5 \mathrm{~A}$ ) coastal vessels ranges from 7 to 19 metres, but almost half of them are 11 metres or less in length, as shown on Figure 3. Gross tonnage (GT) ranges from 3 to $48 \mathrm{GT}$, but almost $80 \%$ of the commercially operated coastal vessels are less than 13 GT (Føroya Skipaskráseting, 2016).

Figure 3: Vessel length and gross tonnage of commercially operated coastal vessels in 2016
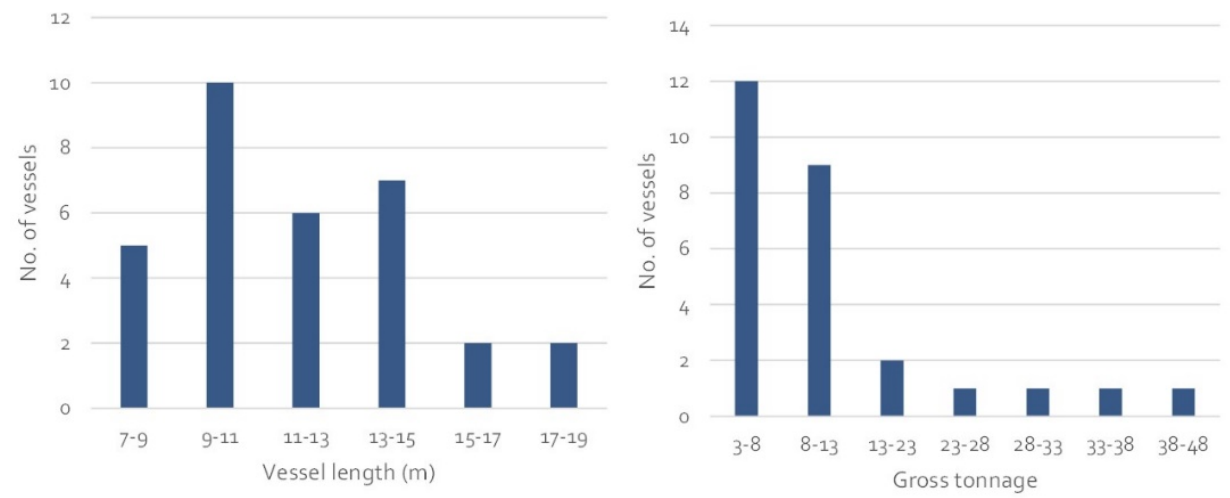

It should however be noted that data on GT was not available for all vessels. Vessel length and GT range are naturally a reflection of the fact that only eight coastal vessels are registered in the larger coastal vessel category.

\subsection{Catches and catch values}

The total catches of the coastal fleet in 2015 was 4,417 tonnes, valued at almost EUR 7.5 million (Vørn, 2017). The catches of the large coastal vessels had declined considerably since the year 2000 and the value along with it. The landing value has gone from 
EUR 6.5 million in 2000 down to less than 1.2 million in 2015 , which is an $82 \%$ reduction. A similar pattern applies to small coastal vessels, both commercial and recreational, but the decline is not as severe. The value of the small commercial vessels' catches was just under EUR 6 million in 2000 and the recreational vessels were at EUR 4.5 million that same year. The value had decreased down to EUR 3.4 million and EUR 3.0 million in 2015 , which is an $11.5 \%$ reduction. Figure 4 shows the total catches and landing values of the coastal fleet 2000-2015 by vessel group (Vørn, 2017).

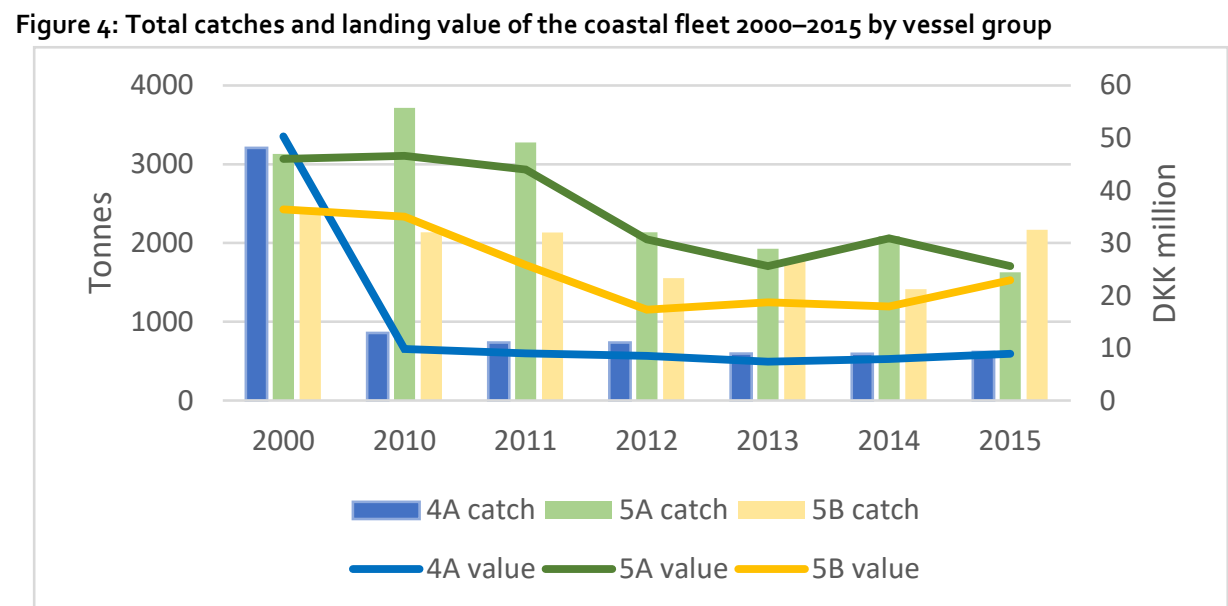

The figure shows that even though the recreational vessels had the highest catch in 2015 , the smaller commercial vessels had the highest value.

Cod, saithe and haddock are the most important species in the coastal fishery. The large coastal vessels catch cod and haddock and some saithe, while small coastal vessels catch predominantly cod. The reduction in catch of these species, especially cod, has been one of the main problems facing the coastal sector in the Faroe Islands in the past years. The catch composition of the three main demersal species is illustrated in Figure 5 (Vørn, 2017). 
Figure 5: Catch composition of the coastal fleet by main demersal species and vessel group

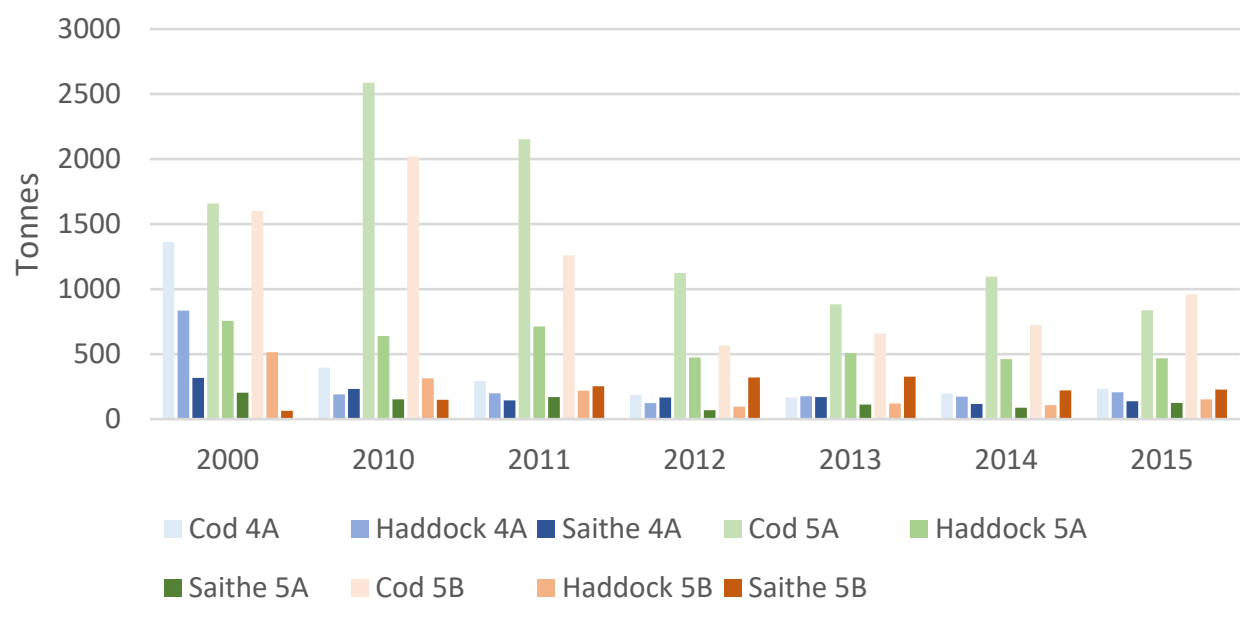

The general reduction in catches does not appear to reflect a reduction in effort quotas, even though fishing day allocation generally has decreased, because utilisation of allocated fishing days has not been remotely close to $100 \%$ in the last few years. Large coastal vessels $(4 \mathrm{~A})$ and the small commercial coastal vessels $(5 \mathrm{~A})$ are allocated individual fishing days and the average utilisation for each group has been $25-31 \%$ for the large coastal vessels and $20-54 \%$ for the small commercial coastal vessels since the fishing year 2010/2011, as shown in Figure 6 (Faroe Marine Research Institute, 2017).

Figure 6: Utilisation of the allocated fishing days by the coastal fleet 2010-2016

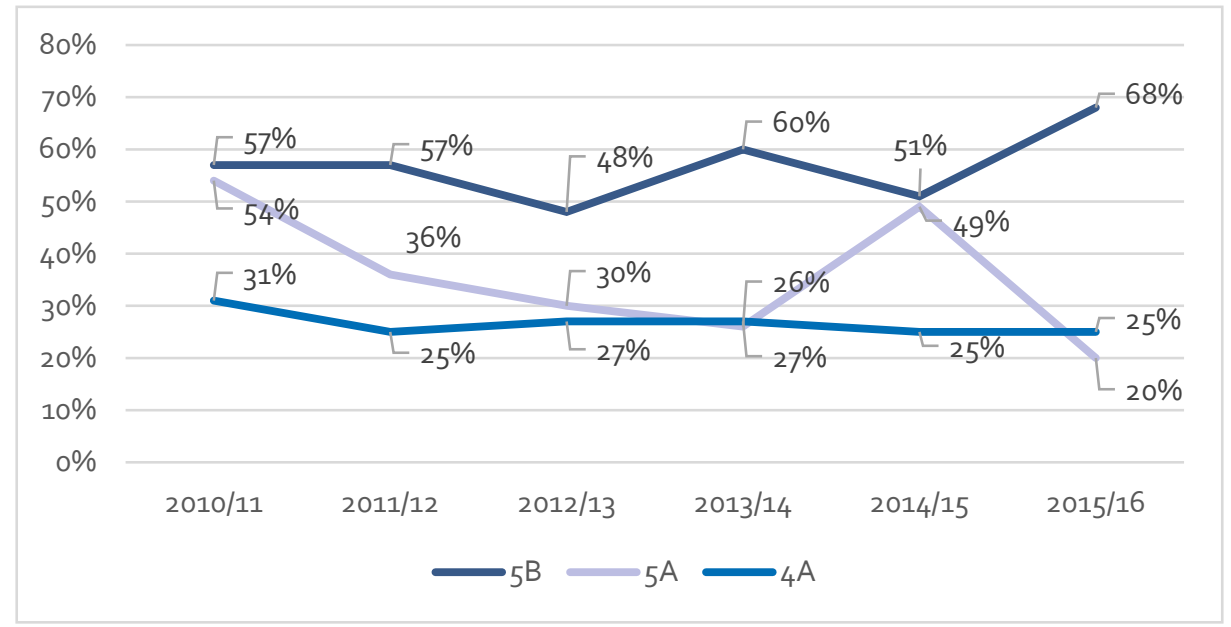

This does not mean that individual vessels have not utilised all their fishing days or more, as fishing days are freely transferable between vessels in the same vessel group (Grétarsson \& Danielsen, 2014). The conclusion must however be that effort is unrestricted, especially with regards to recreational vessels $(5 \mathrm{~B})$, which are allocated fishing days in a common pool and whose utilisation has not gone above $68 \%$ since the fishing year 2010/2011. 
The catch volume and value of the coastal vessels is insignificant compared to the other vessel groups in the Faroese fleet. Total catch value in 2015 was EUR 390 million. The catch value of the large coastal vessels was $0.3 \%$ of the total value, while the small commercial coastal vessels accounted for $0.9 \%$ and the recreational vessels accounted for $0.8 \%$ of the total value, i.e. a combined catch value of $2 \%$, as shown in Figure 7 (Vørn, 2017).

Figure 7: Proportional catch value across vessel groups in 2015

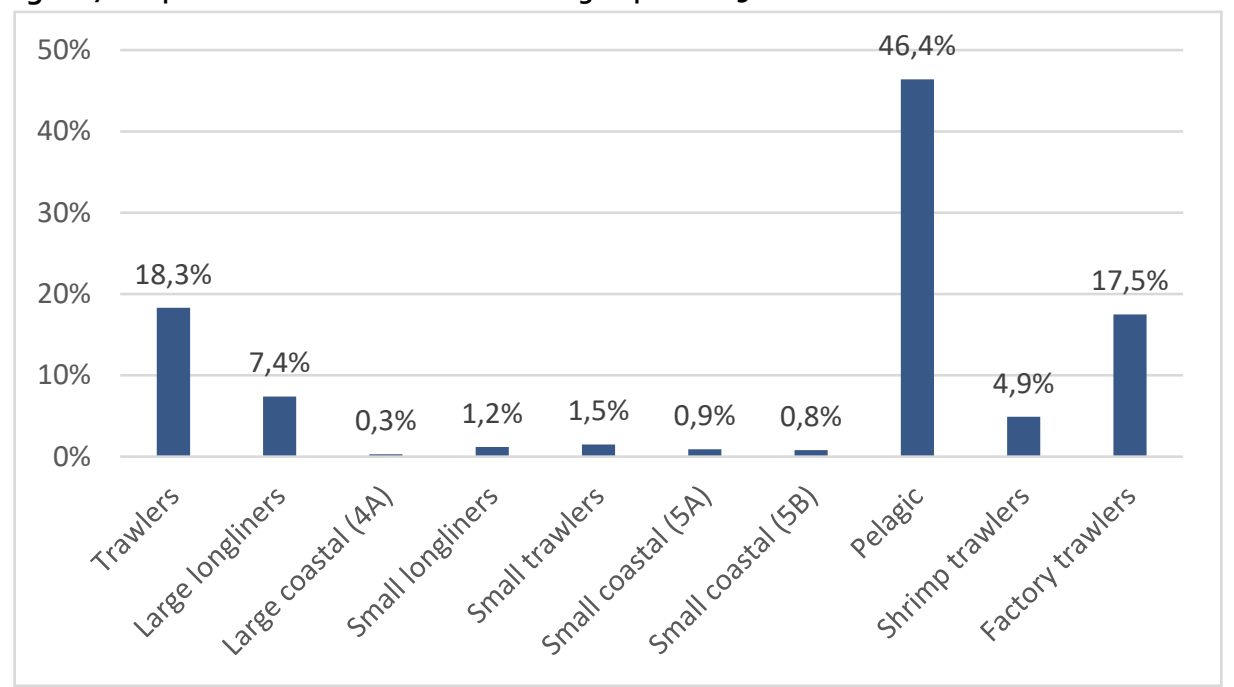

The catch volume of the large coastal vessels accounted for $0.1 \%$ of the total fleet catch while the small commercial coastal vessels accounted for $0.3 \%$ and the recreational vessels accounted for $0.4 \%$ of the volume, i.e. $0.8 \%$ in combination as shown in Figure 8 (Vørn, 2017).

Figure 8: Proportional catch volume across vessel groups in 2015

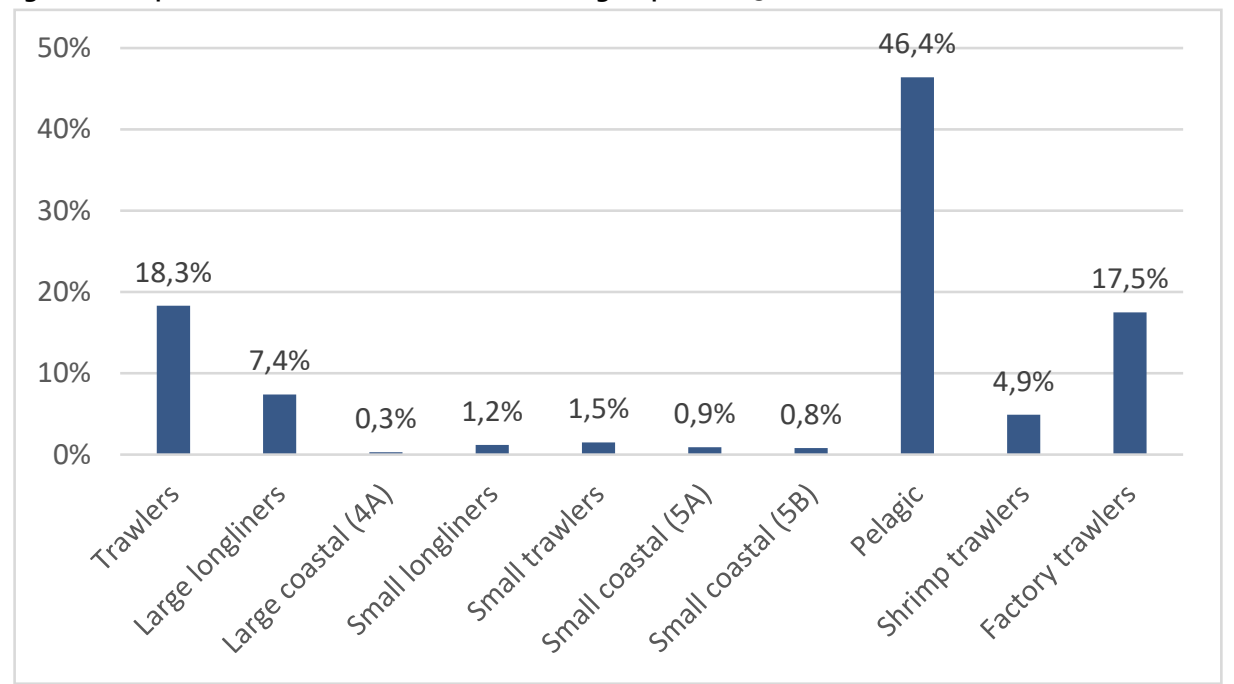


Not all coastal vessels are registered as private companies. In the large coastal segment, three out of six vessels are owned by private companies with publicly accessible annual accounts (balance sheets). In the small commercial segment, 14 of the 27 active vessels were owned by private companies in 2015 (13 in 2013). Vessels in the recreational segment were not looked up in the database due to the sheer number of them and because they are presumably recreational vessels owned by individuals, not private companies. However, based on publicly accessible balance sheets, Earnings Before Interest, Tax, Depreciation, and Amortization (EBITDA) results were calculated for the two segments for the period 2011-2015. The coastal fleet performed better economically in 2014-2015 than in the beginning of the period. The small coastal segment has a total EBITDA of DKK 3.2 million (EUR 416,000) in 2015 compared to 2.5 million in 2011 (EUR 325,000). The average EBITDA for each vessel has also increased in the period from DKK 180,000 to 230,000, as shown in Figure 9 (Business Line, 2017).

Figure 9: Total EBITDA of the 5 A vessel group and average EBITDA per vessel in 2015, in DKK

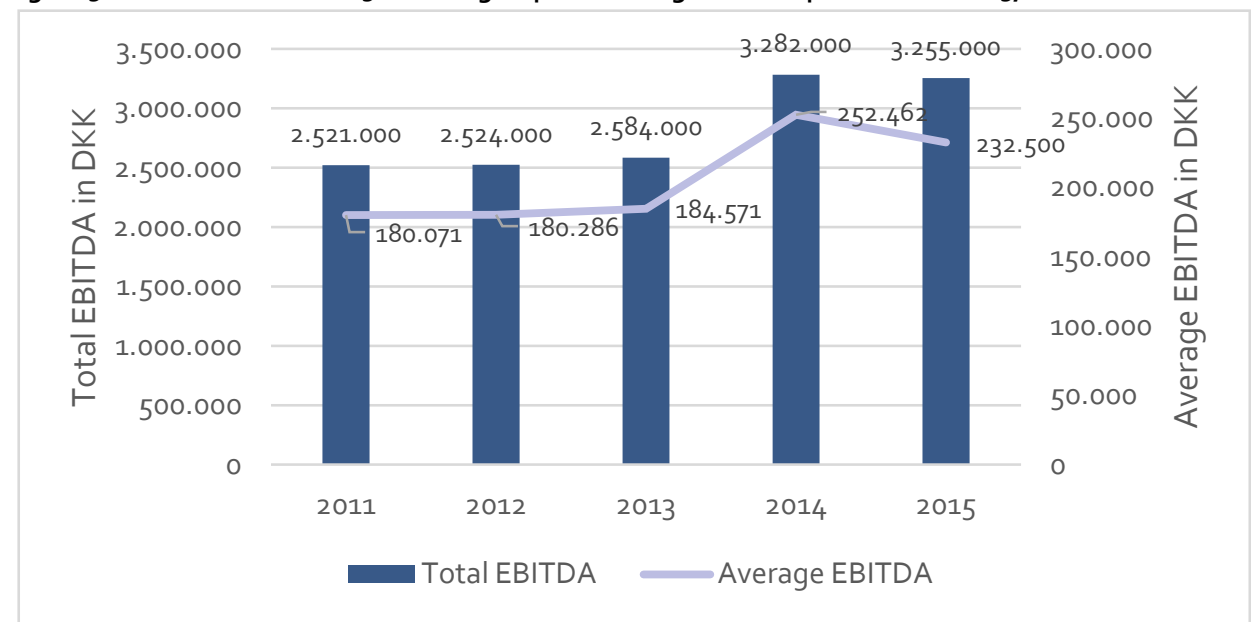

The large coastal vessel segment had a total EBITDA of DKK 1.4 million (EUR 182,000) in 2015, compared to DKK 315,000 (EUR 45,500). In the period 2011-2015, the average EBITDA went from DKK 105,000 to 480,000 , which is a $460 \%$ increase. The total EBITDA in the $4 \mathrm{~A}$ vessel group and average EBITDA per vessel are shown in Figure 10 (Business Line, 2017). 
Figure 10: Total EBITDA of the 4A vessel group and average EBITDA per vessel in 2015, in DKK

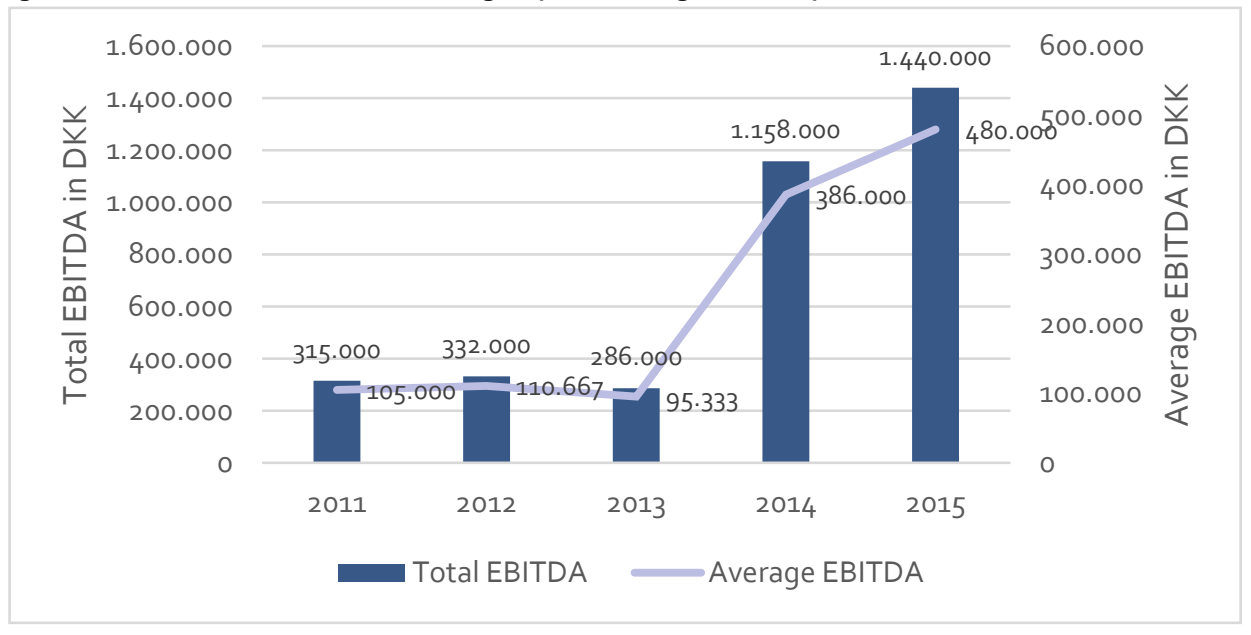

The small coastal sector $5 \mathrm{~A}$ did therefore have a higher total EBITDA, but the large coastal vessels had on the other hand much higher average EBITDA in 2015.

Total EBITDA for the Faroese fleet ${ }^{2}$ ranged between DKK 395-503 million (EUR 51.4-65.4 million) in the years 2011 and 2014. The pelagic fleet had by far the highest EBITDA, accounting for $69-87 \%$ of total EBITDA in 2011-2014. The coastal vessel segments accounted on the other hand for less than $1 \%$ of the total EBITDA in the period, as shown in Table 3 (Business Line, 2017).

Table 3: The share of each vessel group in the total EBITDA of the Faroese fishing fleet 2011-2014

\begin{tabular}{lrrrr} 
& $\mathbf{2 0 1 1}$ & $\mathbf{2 0 1 2}$ & $\mathbf{2 0 1 3}$ & $\mathbf{2 0 1 4}$ \\
\hline Small coastal & $0.5 \%$ & $0.6 \%$ & $0.6 \%$ & $0.7 \%$ \\
Large coastal & $0.1 \%$ & $8.0 \%$ & $0.1 \%$ & $0.2 \%$ \\
Pelagic & $69.0 \%$ & $80.0 \%$ & $87.0 \%$ & $75.0 \%$ \\
Factory trawlers & $16.0 \%$ & $15.0 \%$ & $12.0 \%$ & $19.0 \%$ \\
Large trawlers & $11.0 \%$ & $5.5 \%$ & $0.1 \%$ & $2.9 \%$ \\
Longliners & $2.7 \%$ & $0.0 \%$ & $0.5 \%$ & $2.3 \%$ \\
\hline
\end{tabular}

The extremely profitable pelagic sector makes the comparison possibly unrealistic, but the comparison between the coastal sector and the other demersal sectors operating in Faroese waters i.e. large trawlers and longliners, highlights the difficulties that the coastal sector is in.

The coastal vessels sell their catches usually either on fish auctions or directly to fish processing plants. The fish is then exported, either chilled or frozen, which means that much of the value creation occurs abroad. There is no vertical integration in the Faroese coastal fishery and information on exports that can be broken down to fleet segments are not available, which makes it difficult to estimate how much value is

${ }^{2}$ Some small fleet segments were left out due to lack of data. 
added to the coastal catches in Faroe Islands. Figure 11 shows how much fish was exported from Faroe Islands 1993-2015 by product category (Hagstova Føroya, 2017b).

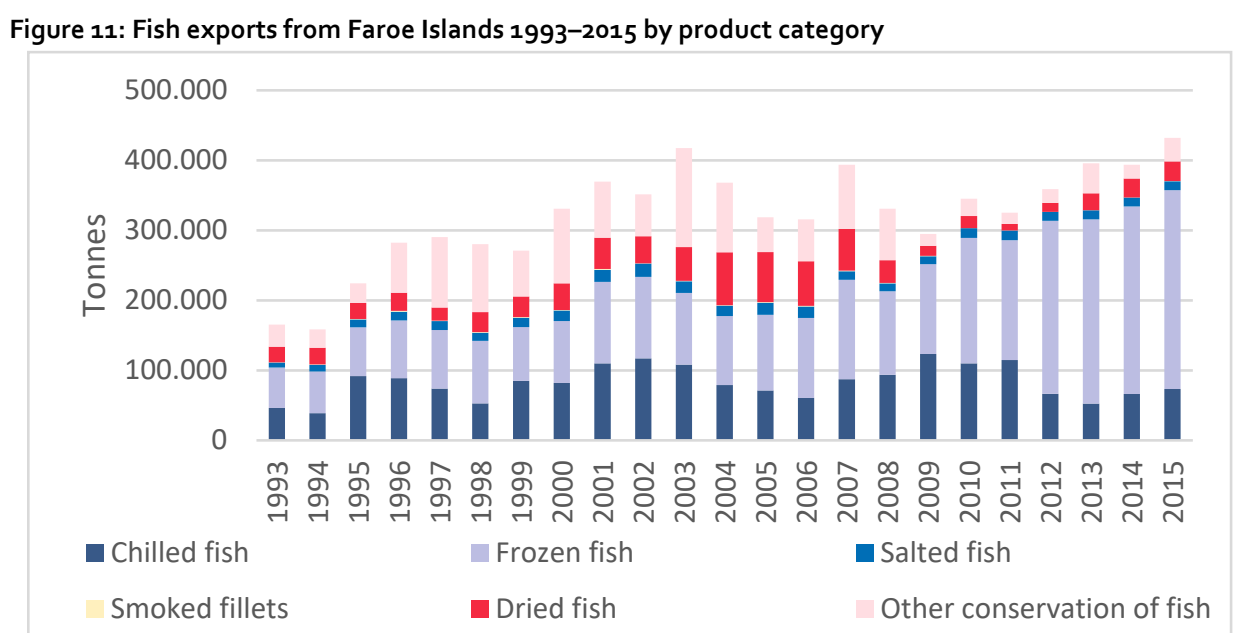

There is no available data on the difference in prices between fish auctions and processing plants, although it is natural to assume that prices are generally higher at the auctions. To stabilise incomes for coastal fishermen, an attempt was made a few years ago to create a partnership between coastal fishermen and processing plants, in which coastal fishermen agreed to provide processing plants with high-quality fish in return for stable prices and incomes year-round. The attempt failed however, partly because self-employed fishermen are incentivised by good prices (Gregersen, 2016).

\subsection{Socioeconomic effects}

It is clear from the data on EBITDA that the economic performance of the coastal sector is relatively unstable, although there is no official data on employment or wages in the coastal sector in Faroe Islands. Of the three larger coastal vessels that are owned by private companies, one paid wages in the range of DKK $750,000-1,700,000$ (EUR 97,500-221,000), the second in the range of DKK 1.2-1.5 million (EUR 156,000195,000), and the third paid almost no wages at all in the years 2011-2015 (Business Line, 2017). It is not clear how many people are paid from these sums but it is reasonable to assume that around two to three men work on each of the larger coastal vessels. Using the higher value, only one of the vessels paid consistently good wages within the period. Assuming that two to three people work on each boat, the larger coastal segment employs 12-18 people if all active vessels are included.

In the smaller coastal segment, each vessel paid wages in the range of DKK 580,000-620,000 (EUR 75,400-80,600) on average in 2011-2015. However, the individual vessels' wage expenses range from zero to DKK 1.9 million (Business Line, 2017). These vessels are most likely operated by one or two people, which means that wages can be quite high, but some may not be paid any wages at all. Assuming each vessel employs one to two people, the 27 active vessels employ around 27-54 people. 
These numbers indicate that the coastal fleet in Faroe Islands employs between 39-72 people in total. To put this into perspective, approximately 1,500 people worked in wild capture fisheries and 1,400 in fish processing in 2016, and the total active workforce of the Faroe Islands in 2016 was 29,000 people, meaning that the coastal sector only employs $0.1-0.2 \%$ of the Faroese population (Hagstova Føroya, 2017a).

It is clear, that the economic contribution from the coastal fleet is insignificant, and given that, its influence on regional development must be relatively small. This is especially true given the geography of the Faroe Islands, which many would probably consider one region. There are only $112 \mathrm{~km}$ from the most southern tip of the islands to the most northern tip and transportation links between the islands are very good. Of the 18 islands, six are connected by bridge or underwater tunnels, which means that most of the population lives within an hour's drive or so of the capital, Tórshavn, which is by far the largest city. Two large islands are still not connected by an underwater tunnel, Sandoy and Suðuroy, but an underwater tunnel to the former will be completed within in the next few years, leaving only Suduroy not connected to the rest of the islands. Sailing time from Suðuroy, the southernmost island, to the capital is two hours and there are several daily departures. Suðuroy is commonly perceived to have regional development problems and the population of Suðuroy has decreased by 1,200 in the last three decades, a decrease of around 22\% (Hagstova Føroya, 2017a).

The fishing grounds targeted by the coastal fleet are located all around the islands and thus the best fishing grounds are easily accessible from any location (Danielsen, 2014). Six coastal vessels are active on Suðuroy, which even though it is more than in most other regions, does not provide many jobs, as per the above estimations. Upon mapping of registered active coastal vessels, it is however clear that most coastal vessels are registered outside the capital. Therefore, it is possible that coastal vessels are an important opportunity for self-employment in villages that do not have many employers, but given the data we have seen in previous sections, the coastal fishing fleet is not going to reverse the population trend in Suðuroy or in any other region; especially not with the current number of active vessels. Figure 12 shows the location of coastal vessels in Faroe Islands i.e. number of vessels in each harbour/island (Vørn, 2017). 


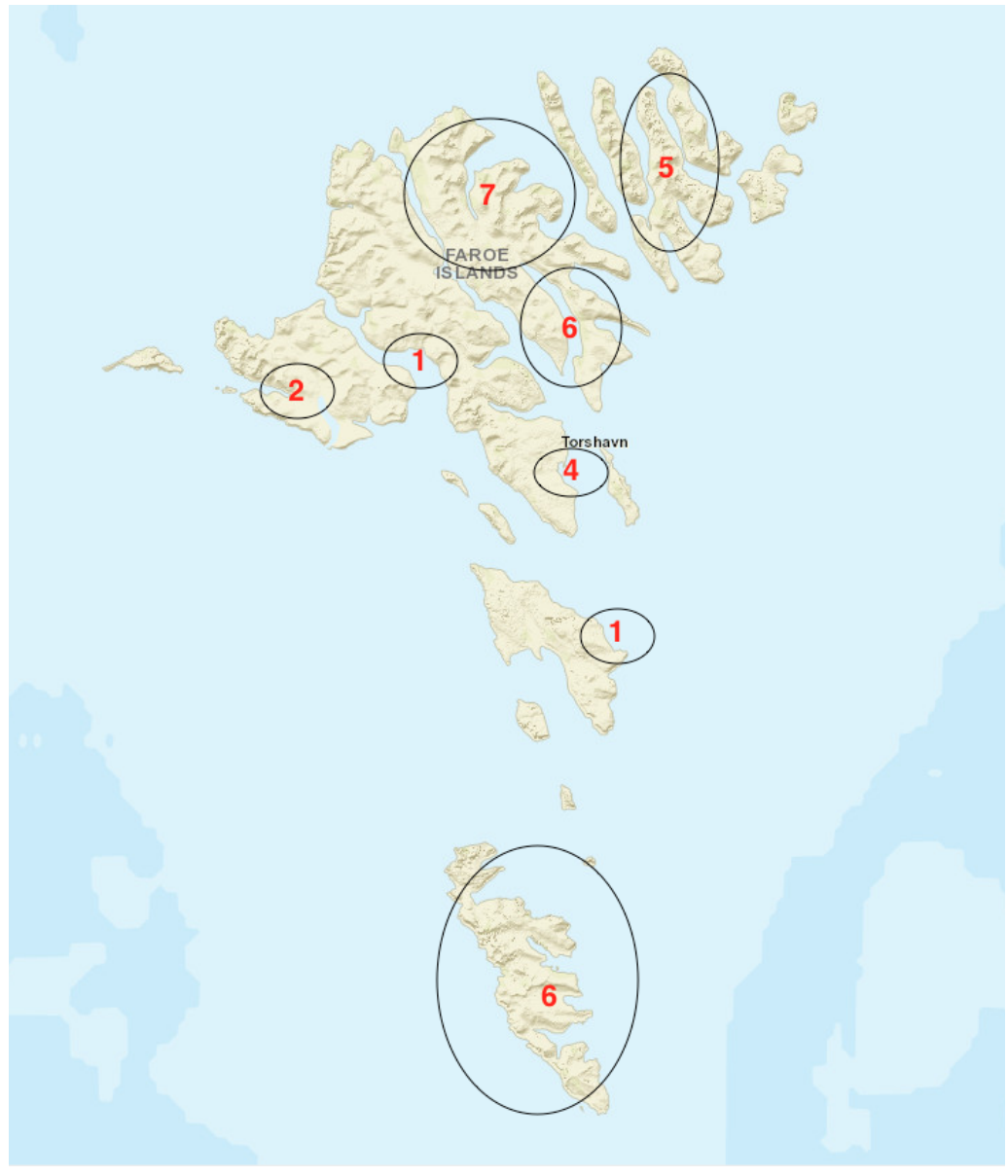

This could potentially change if the Faroese restructured the composition of their fleet, but entering the fishery is costly, even the coastal fishery. To enter the fishery, purchase of a vessel with a fishing licence is needed, which means that for most people the vessel needs to fish enough to make a profit in order to be worth the investment. This is clearly not the case with all vessels, as shown earlier - some vessels are not even registered as companies even though they are meant to be operating commercially, while other vessels pay no wages. This is at least partly due to the historically small demersal stocks in the Faroe Islands. However, the coastal fishery provides opportunities for selfemployment because it is possible to enter the fishery with a recreational licence and fish your way to a commercial license, which will give you individual fishing days and more secure rights to the resource. In addition, some vessels are expanding into the pelagic fishery. But at the end of the day, being a coastal fisherman is not perceived as a desirable profession, as evidenced by the average age of fishermen in the sector, which is 57 years in $5 \mathrm{~A}$ and 68 in $5 \mathrm{~B}$ (Danielsen, 2014).

The outer regions are being connected to the main islands by tunnels and new roads and ferries are planned. This will aid the growth of those towns and villages and prevent 
stagnation or decrease in population. On the island of Sandoy land for new houses is being prepared in connection with the future underwater tunnel. Tourism is also growing in the Faroe Islands, resulting in a growing demand for birdwatching, whale watching, recreational angling, leisure sailing, as well as regular transportation by boat. In some outer regions hotels have also been rising. This may provide jobs for people in the outer regions in the short and long term and increase service supply in the long term.

There are also huge opportunities for value adding fish resources in the Faroe Islands, as most fish is exported frozen or chilled, and most fish factories are located in the outer regions, so the added value from this could potentially spill into the wider community. In addition, there are great opportunities in value creation of fisheries products where more of the rest raw material from fisheries could be utilised, e.g. by bringing liver, roes, heads, viscera etc. ashore.

\section{$1.4 \quad$ Challenges and opportunities}

The main strengths of the Faroese coastal sector are that for the most part it makes a relatively good income; there is no lack of fishing days and there is good knowledge among fishermen on the fishery i.e. handling, fishing grounds etc. The coastal sector is also largely situated in remote areas, where housing cost is low, compared to Torshavn.

The most challenging weaknesses are that the demersal stocks are in pore condition, many of the vessels have low revenues and the EBITDA is very low in comparison with other fleet segments. Another weakness is that monitoring and control within the coastal sector is low.

There are a number of opportunities within the coastal sector. Some coastal vessels are for example entering the pelagic fishery, which can provide immense possibilities for increased income. The sector also provides opportunities for new entry, as commercial licences can be obtained from increased landings in recreational fisheries; allowing smallscale fishermen the opportunity to evolve towards commercialization. There are also opportunities for diverse product development within the sector, as most fish is exported frozen or chilled and most value-added processing is carried out abroad. Utilization of rest raw material, such as liver, roe, milt and skin can be improved. Foreseen improvements in road infrastructure and transportation can provide opportunities to reverse the population decrease in remote areas and ease logistical challenges that the coastal sector has had to deal with in the past. Finally, there is a growing tourism in the Faroe Islands and there are definite opportunities for the coastal sector to benefit from that i.e. sea angling, bird watching, whale watching, pleasure sailing etc.

There are also large threats facing the Faroese coastal sector. The biggest threat is that the demersal stocks will not recuperate, but continue to decline. There is also a good chance that current trends where people continue to move from remote areas to larger cities will continue, partly due to limited educational opportunities. There is also a limit to what services small communities can provide, particularly when their income decreases from year to year. These rural areas do also seldom provide job opportunities for young, educated people or for women. 


\section{Greenland}

Greenland, the world's largest non-continental island. It is inhabited by just over 55 thousand people, with most of the people living along the ice-free coast (Statistics Greenland, 2017a). The population is largely concentrated in settlements near fishing ports, indicating the importance of fisheries for the small nation. The country is divided into four municipalities, usually containing one principle town and several rural villages and settlements along the coast, many of which are entirely dependent on fishing and hunting. Fishing is the primary industry in Greenland where the coastal fleet plays an important role in the economy and regional development. The most valuable species today are the northern prawn, and Greenland halibut, both of which are regulated by quota and license regulation governed by the government. These two species accounted for $80 \%$ of landing value of the coastal fleet in 2016 . The coastal fleet landed 124 thousand tonnes of catches in 2016, valued at EUR 165 million in total. The importance of the sector for the Greenlandic society is though much greater, when considering its contribution to total export values, rural development and food security. Figure 13 shows the four municipalities in Greenland.

Figure 13: Map showing the four municipalities of Greenland

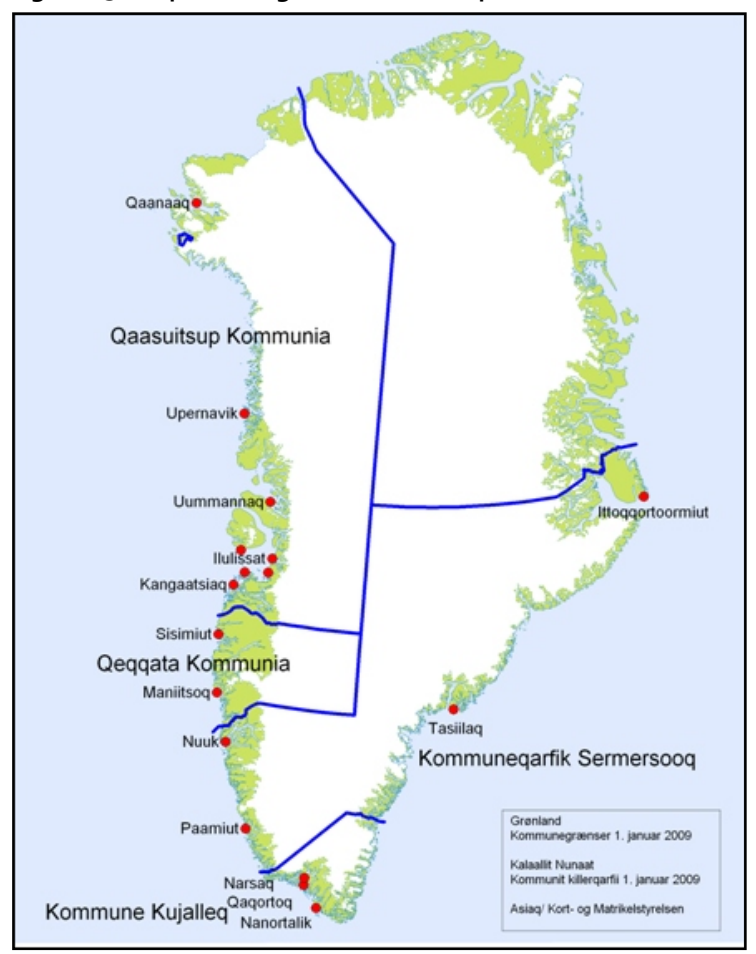

Source: Asiaq 


\subsection{The coastal fleet}

The definition of a coastal vessel in Greenland relates to where the vessel can fish, rather than the vessel size, gear type or effort capabilities. For this reason, the Greenlandic coastal fleet is highly diverse regarding size, equipment and operation. The fleet can be divided into the following three main categories:

1. Coastal shrimp trawlers: These vessels can fish within the baseline and are usually significantly larger than what most people would consider as typical coastal vessels. In 2016 a total of 22 vessels belonged to this group, most of which were 80-800 GT. Vessels in this group can apply for exemptions from the 120 GT upper limit for coastal vessels.

2. Larger coastal vessels: These vessels need to be registered with the Danish Maritime Authority, i.e. have GR numbers and are thus often referred to as "GR vessels". They are primarily made of wood or steel and the typical size is 20-70 GT (30-70 feet long). These GR vessels were 294 in total in 2013.

3. Small open dinghies: These vessels are 14-21 feet long, many of which do not even have cabins or any other shelter. Various types of fisheries are conducted in these vessels, such as cod, lumpfish, Greenland halibut, etc. The total number of vessels in this group is not known, as they don't require registering and can either hold a few different licences or no license at all and only be used for fishing for own consumption. The number is estimated at around 1,500 in total.

The Greenlandic fishing fleet is quite old, with an average age of well over 40 years. Most of the vessels are in the Qaasuitsup municipality, which spans over the northern part of the West-coast. There are also considerable numbers of Greenlandic vessels in the Sermersooq and Qeqqata municipalities, situated on the south-western part of the country. There are however relatively few coastal vessels in Kujalleq municipality, which is the most southern municipality, as shown in Table 4 (Berthelsen, 2017).

Table 4: Number and average age of coastal vessels according to municipalities

$\begin{array}{lrr}\text { Municipality } & \text { No. of vessels } & \text { Average age } \\ \text { Kujalleq (south) } & 38 & 44 \\ \text { Sermersooq } & 86 & 43 \\ \text { Qeqqata (mid) } & 63 & 47 \\ \text { Oaasuitsup (north) } & 107 & 45 \\ \text { Total } & 294 & \end{array}$

This distribution of the coastal vessels in Greenland demonstrates the importance of the sector in the northern regions of the country. In the southern regions, farming and other industries are more important.

Fisheries in Greenland are managed through quotas and licenses regulating the total allowable catch (TAC) within Greenlandic waters. The fleet is categorized into 
the following three segments: the off-shore fleet, in-shore fleet/coastal fleet and foreign fleet.

The Government of Greenland sets annual TAC limits for fish stocks within Greenlandic waters, based on scientific advice by the Pinngortitaleriffik (Greenland Institute of Natural Resources). The Fisheries Council, consisting, among others, of representatives from the Association for Coastal Fishermen and Hunters in Greenland (Kalaallit Nunaani Aalisartut Piniartullu Kattuffiat, KNAPK) and the employers' associations (GE and NUSUKA), are consulted before the TAC is set. The TAC is distributed in the form of quotas to individual units of the fleet, where the off-shore fleet is allocated $57 \%$ of the total shrimp quota for West Greenland, while the remaining $43 \%$ are allocated to the coastal fleet. The distribution of quotas for other species is determined by the Greenlandic government.

Licenses are issued to grant fishing rights, and since 2008 , the licensing system has been used to regulate both the off-shore fisheries (shrimp, halibut, crab, cod, redfish, halibut, capelin and grenadier) and the coastal fisheries (shrimp, halibut, crab, salmon, lumpfish and scallops). A distinction is made between three types of licenses; temporary licenses with or without an upper limit for the allowable catch and permanent licenses with an upper limit for the allowable catch. Permanent licenses with a maximum allowable catch are used for shrimp. The individual shipping companies or persons have license to catch a certain share of the quota of their fleet segment. After setting the TAC, the government notifies the license holders of their allocated annual quota.

Licenses, which are issued for one year at a time, can be traded between ship owners and individuals. In the off-shore shrimp fishery, one single company or individual can, at the most, hold one third of the total shrimp quota. In the coastal shrimp fishing, the maximum share is $10 \%$ of the total quota. Temporary licenses with an upper limit for the allowable catch are used in the off-shore fleet targeting halibut, cod, redfish, capelin and grenadier. In the coastal sector, these types of licenses are required when fishing for scallops. Each fishery is subjected to a different set of rules and regulations. Further explanations on the regulatory systems affecting coastal fisheries in the main coastal fisheries are as follows:

\subsubsection{Common fishing licenses}

The Greenlandic Parliament (Inatsisartut) issues fishing licenses in Greenlandic waters (Parliament, 1996). To attain a licence as a fisherman, it's necessary to have a background in Greenlandic fisheries and have been engaged as a full-time fisherman for at least two years, where at least $50 \%$ of the individual's gross income must be generated from fisheries. With such a license, fishermen can fish freely (Olympic fisheries with total TAC) for cod, redfish, catfish, capelin, salmon and few other species (in insignificant amounts though). The regulations do not distinguish between fisheries using different gears. Cod fisheries are the most important one within this category. 


\subsubsection{Shrimp fisheries quota system}

Every year the Government (Naalakkersuisut) in Greenland allocates licenses for the shrimp fishery. There are four types of licenses that are issued, and only one of these are allocated to the coastal vessels.

\subsubsection{Greenland halibut costal system}

The costal Greenland halibut fishery is divided into two main areas, with separate management regulations, south and north of $68^{\circ} 50^{\prime} \mathrm{N}$. A special halibut license is needed for both areas. In the southern fishery, it is obligatory to sell all the catch to processing companies, and in 2016 a total of 4,077 tonnes of Greenland halibut were sold to the producers (Berthelsen, 2017). In the northern fishery, the area is divided into three management areas; Diskobay, Uummannaq and Upernavik. The Greenland halibut fishery in these three areas is the most important fishery for the whole costal sector in terms of value, with more than 24,000 tonnes being landed in that area in 2016, valued at ERU 59.8 million. Coastal fisheries of the Greenland halibut are subjected to a vessel size limitation, as only vessels less than 32 GT can enter the fishery ${ }^{3}$ set as a precaution to protect the stock and ensure sustainability of the fishery.

\subsubsection{Lumpfish fishery}

The lumpfish fishery is highly important for the Greenlandic coastal sector, both regarding value and regional development. The yearly catch delivers about 8 thousand barrels of roes, which are caught by roughly 500 vessels or to be more precise from dinghies. There are considerable fluctuations in catches and value between years, partly because of highly unstable markets.

A completely new regulatory system was introduced before the 2014 lumpfish season (Government of Greenland, 2014) that contains several restrictive measures. For the first time in history, quotas and a maximum number of fishing days have been introduced to the fishery and resources have been allocated to carry out biological surveys for stock assessment. These stricter management measures and increased focus on stock sustainability is based on that Greenland applied for and obtained the sustainable certification of the Marine Stewardship Council (MSC) in 2015.

Even though the vessel size limits for the lumpfish coastal fisheries is 120 GT, only a handful of boats that exceed 30 feet ( 9.1 meters) are currently engaged in the fishery, mainly used as service-boats (for sleeping, showering, eating, etc.). The lumpfish fishery is subjected to a special licensing, which is valid for two years at a time, allocated for a certain number of days in each fishing season ( 47 days in 2014). Each license is valid for the entire area of Northwest Atlantic Fisheries Organisation (NAFO), meaning that a licence holder can start from south and follow the stock north. Estimating the best time to start the fishery can be a challenge for the local producers and the fisheries

3 Executive Order no. 2, 2 February 2012 Coastnear Fisheries for Greenland halibut, section 1. 
society in each fishing area and depends on when both parties believe the quality of roes is good enough to declare the season open. At that point, fishermen can start laying out nets and fishing days will count from that point on.

\subsubsection{Cod}

A license for cod fishing in Greenlandic waters simply requires a general fishing and hunting license and all cod catches are to be landed to local processors. Fishing in East Greenland is mainly off-shore bottom trawling while the coastal fishery is conducted on the West coast. The main fishing gear used in the cod fishery is Danish model trap, or "poundnet" (bundgarn) which accounts for approximately 90\% of the catches. The traditional high season is in May and June, but in recent years the season has been expanding further into the summer/autumn all the way to September. Hand-operated jigging and gillnets are also used to some extent. The cod stock has been in a slump for the past two decades, but is now showing strong signs of recovery.

\subsection{Catches and catch values}

The Greenlandic economy is highly dependent on the fishing industry, with its contribution reported to be as high as $25-30 \%$ of GDP (McBean, 2004). The rural villages and settlements along the coast, which often have about 150 inhabitants in each village, are entirely dependent on fishing and hunting. In 2016 the Greenlandic coastal sector landed 124 thousand tonnes, valued at EUR 165 million. Northern prawn and Greenland halibut accounted for $80 \%$ of the landing value, prawns stood for $31 \%$ and Greenland halibut for $49 \%$ of the total value. The third and fourth most valuable species were cod and snow-crab, accounting for $15 \%$ and $3 \%$ of the landing value (Statistics Greenland, 2014b). Table 5 shows the value of Greenlandic coastal fisheries for each of the four municipalities and the share of the population in each municipality.

Table 5: The value of Greenlandic coastal fisheries in 2013 by municipality

\begin{tabular}{lrrrrr} 
Municipality & $\begin{array}{r}\text { Value } \\
\text { (mill. DKK) }\end{array}$ & $\begin{array}{r}\text { Value } \\
\text { (mill. EUR) }\end{array}$ & Share of value & $\begin{array}{r}\text { Share of } \\
\text { population }\end{array}$ & $\begin{array}{r}\text { Average value / } \\
\text { habitant (€) }\end{array}$ \\
Qaasuitsup & 735 & 95 & $58 \%$ & $31 \%$ & 5,569 \\
Qeqqata & 228 & 30 & $18 \%$ & $16 \%$ & 3,321 \\
Sermersooq & 183 & 24 & $14 \%$ & $41 \%$ & 1,050 \\
Kujalleq & 38 & 5 & $3 \%$ & $12 \%$ & 755 \\
Over-the-side & 87 & 11 & $7 \%$ & $100 \%$ & 2,987 \\
Total & 1,271 & 165 & $100 \%$ & & \\
\hline
\end{tabular}

The table further demonstrates the importance of the coastal sector for the municipalities in the north of Greenland, especially the share of the sector in the economy of Qaasuitsup. These settlements in the northern part of the country have been struggling in regards to rural development issues, as many young people have moved to the larger cities, a development that would have been even more severe if not for the strength of the coastal 
sector. The importance of the coastal sector for Sermersooq should however not be underestimated. Although the average value of the sector per capita is lower in Sermersooq than in Qaasuitsup and Qeqqata, it must be noted that the capital of Nuuk is in Sermersooq, meaning that other industries play a bigger role there than in other municipalities. The coastal sector has the least impact for the municipality of Kujalleq in the south, which is more dependent on farming and tourism.

Landing volumes and values of the coastal fleet for the most important species in 2016, by landing harbour, can be seen in Figure 14 and Figure 15 (Statistics Greenland, $2017 \mathrm{~b}$ ). The figures show clearly the importance of the Northern prawn, Greenland halibut and lumpfish.

Figure 14: Landings (tonnes) of coastal catches in 2016 by landing harbour

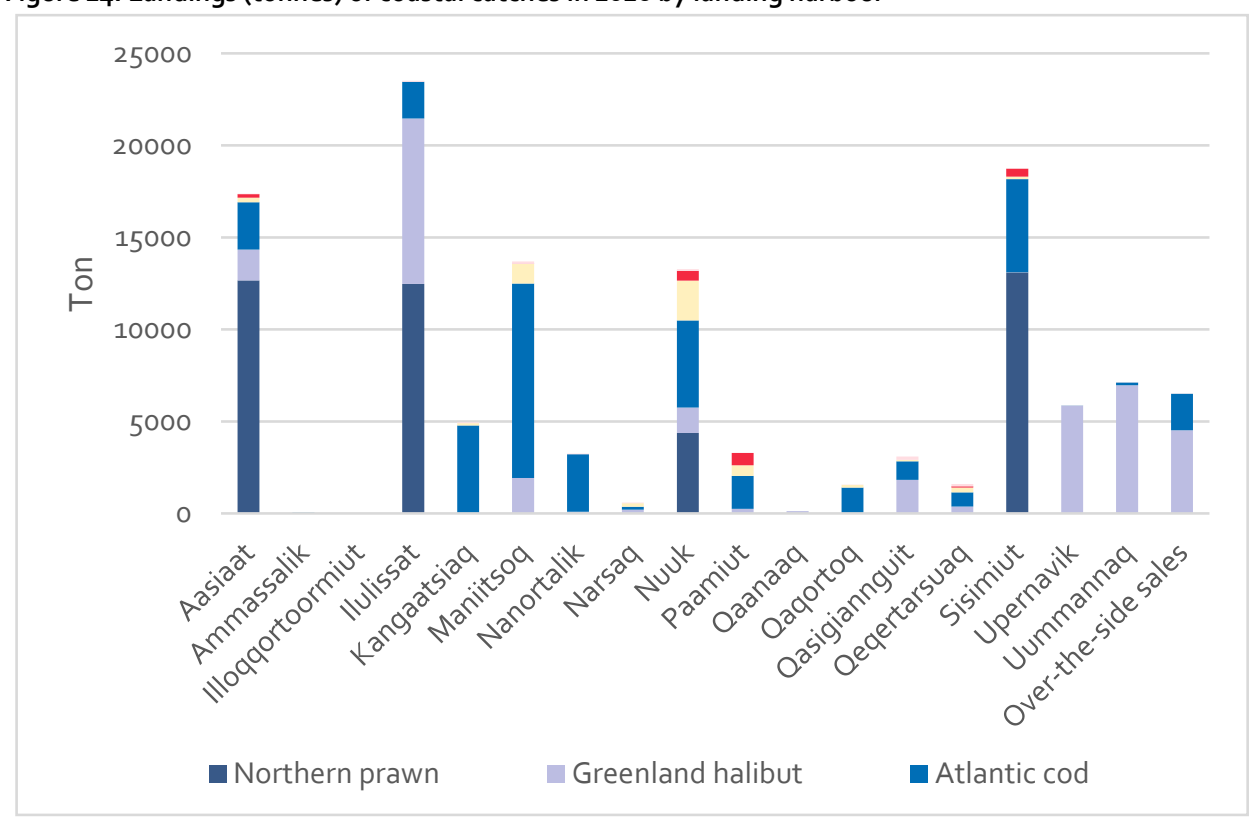


Figure 15: Landing value of coastal catches in 2016 by species and landing harbour

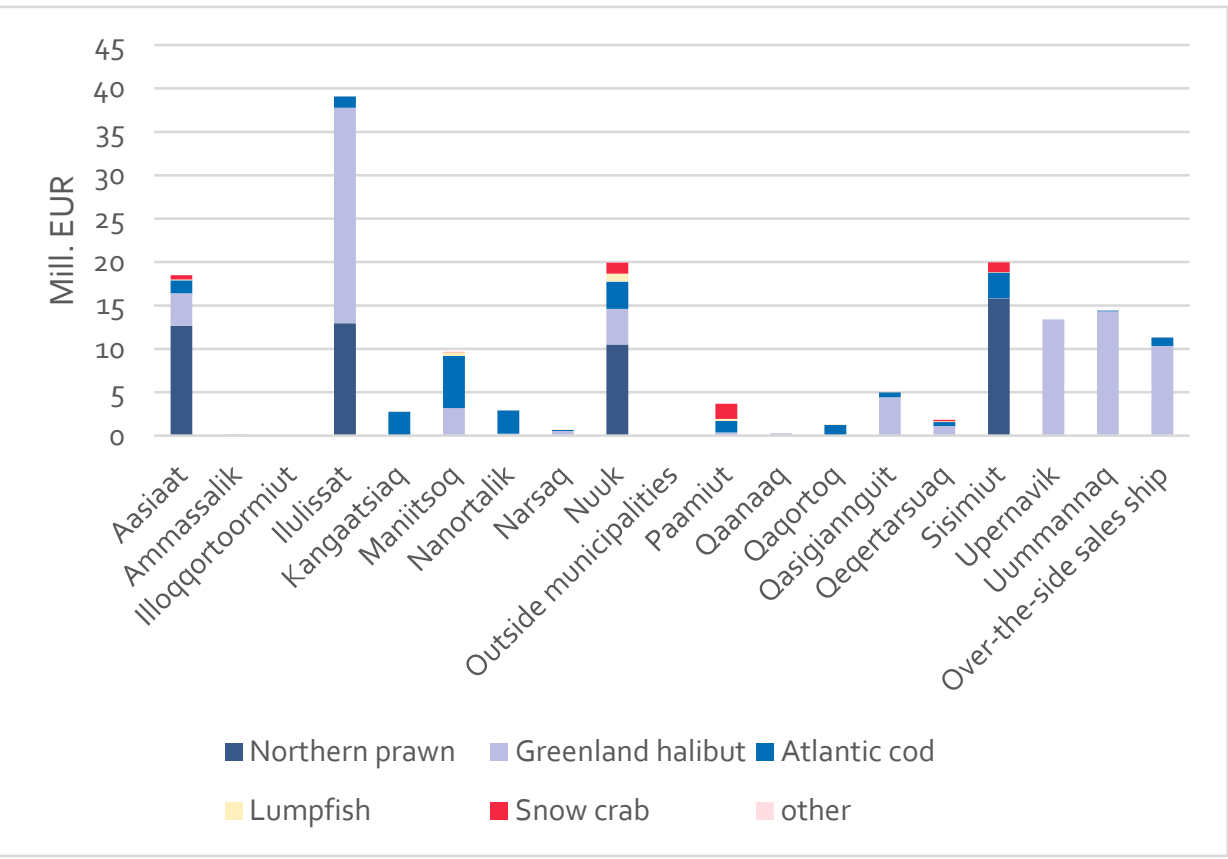

Ilulissat stands out in regards to total landing value of coastal catches, as it has the highest value in Greenland halibut and a large porportion of the Northern prawn. Nuuk, Sisimiut and Aasiaat are the other three towns with prawn processing, which explains their considerable share in the total value. Uummannaq and Upernavik then have a significant interest in the Greenland halibut fishery, while the other settlements represent a much smaller portion in the total landing value of coastal catches.

The numbers presented in Figure 16 show that the distribution of species with respect to fishing areas is not equal. It should also be considered that the type of vessels and fishing gear mainly used in each area depends on the target species. As an example, trawling, which accounted for $42 \%$ of coastal catches in Greenland in 2013 and is mainly used in the northern prawn fishery, requires larger vessels. But as there are only four prawn processing plants operated in Greenland today, the fishery has certain limitations regarding regional development in rural areas.

Jig and line accounted for $43 \%$ of the coastal catches in 2013 , where the most important species is Greenland halibut. This fishery is conducted using small boats and is of importance for settlements of all sizes i.e. is very important for regional development. The same applies for gillnetters, where the most important species is lumpfish. The lumpfish fishery is conducted on small dinghies and is very important for small and medium sized settlements. Figure 16 shows the portion of each fishing gear in total coastal catches in 2013 (Berthelsen, 2017). 
Figure 16: Portion of each fishing gear in total Greenlandic coastal catches 2013

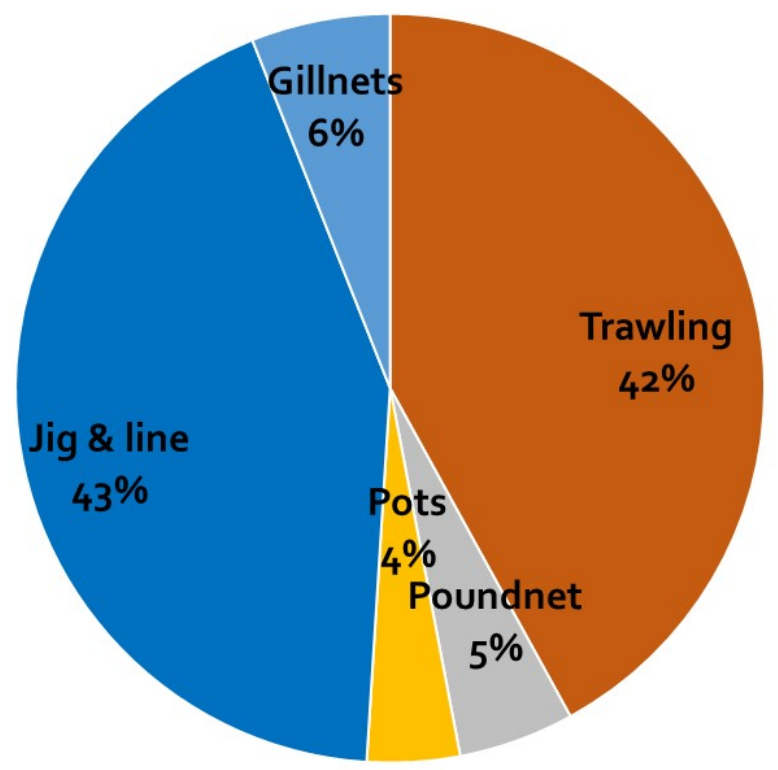

Poundnets, which are large traps set out close to shore, are primarily used to fish for cod. Poundnets accounted for $5 \%$ of the coastal catches in 2013 , but its importance is not significant as the fishery is low value and highly seasonal. The cod fishery is though expected to become more important in the near future, as stock estimates expect that the cod stock will increase dramatically. The Greenland Natural Institute has even mentioned figures exceeding 200,000 MT as possible future annual catches. This increasing stock size of cod has already begun to be seen in the catches of the coastal fleet, as cod catches quadrupled between 2012 and 2016, as shown in Figure 17 (Statistics Greenland, 2017b).

Figure 17: Coastal catches of Atlantic cod 2000-2016

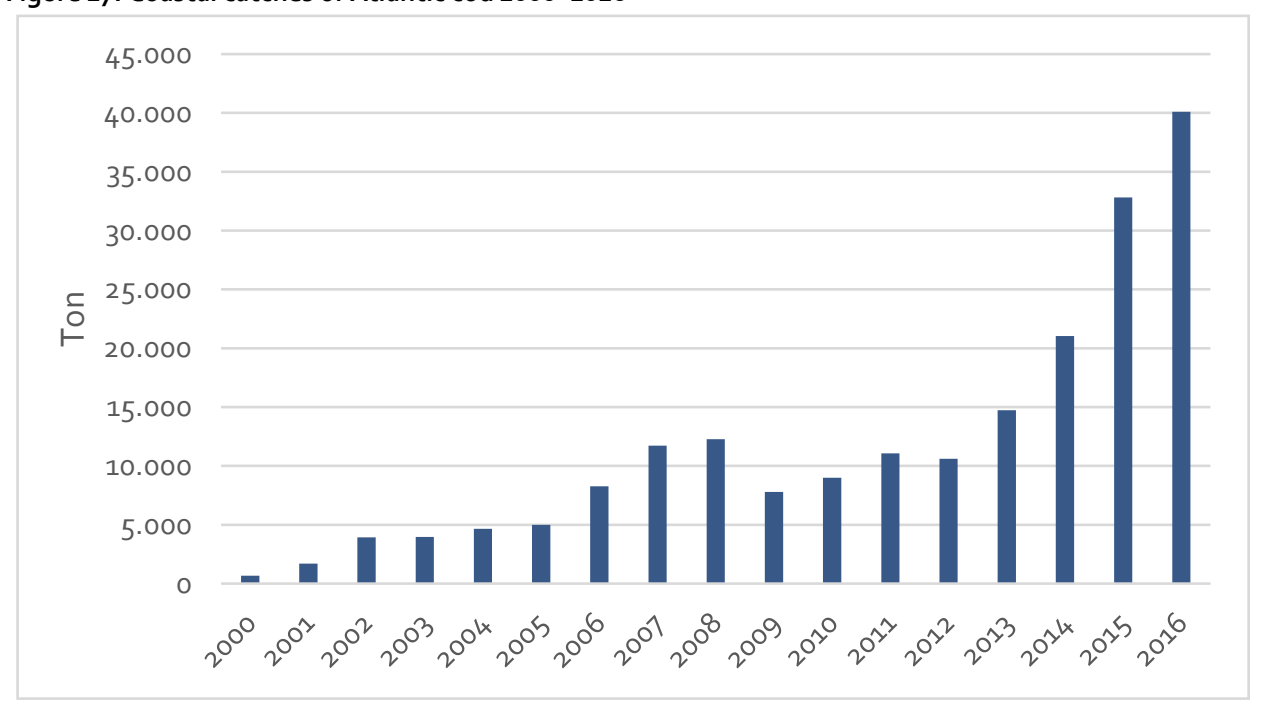


The increasing cod catches have however not resulted in as much value creation for the coastal sector as hoped for. The challenging issue with the cod catches are that the fishery is highly seasonal i.e. are almost solely during the summer months, the quality is highly variable, there are few processors willing to buy the catch, logistical issues within Greenland complicate matters etc. The cod is therefore largely used for own consumption and as feed for the dogs, but there are considerable potentials in the cod fishery. The total landing value of the 40 thousand tonnes landed in 2016 was 25 million EUR, which is only EUR $0.65 / \mathrm{kg}$. But as shown on Figure 15 the cod has become extremely important for some of the villages around Greenland e.g. Maniitsoq, Kangaatsiaq and Nanortalik.

Fish from the demersal fleet in Greenland is mainly transported abroad, but the rest is sold to people within the villages, towns and cities. Transportation and access to markets is of importance when considering fisheries and regional development issues with respect to coastal fisheries in Greenland. Transportation is a major barrier for profitable processing in the country and that directly affects the catching sector. In 2016 , the average landing value of cod was only EUR $0.65 / \mathrm{kg}$, which is extremely low in comparison with what is paid for cod in other Nordic countries (Statistics Greenland, 2017b). On average, the return of investment is relatively slow due to low prices paid for the fish. Marketing and ownership issues are a big factor, which is highlighted by that in $2016,81 \%$ of Greenlandic exports were transported to just one country i.e. Denmark (60.4\%). Majority of the exports go to Europe, however. In 2016 seafood exports from Greenland accounted for $92.8 \%$ of the total export value, of which shrimp accounted for $41 \%$ and Greenland halibut for 29\% (Statistics Greenland, 2017a).

\subsection{Socioeconomic effects}

There are 310 Greenlandic fishing vessels registered in the Danish Maritime Authority's registry, of which 294 are classified as coastal vessels i.e. with licenses to fish within 3 NM of baseline and under 120 GT in size (Danish Maritime Authority, 2012). The baseline is a line drawn between coastlines/islands reaching furthest into the sea, as shown in Figure 18. Greenlandic offshore vessels cannot fish closer to shore than up to the baseline and foreign vessels holding a quota in Greenlandic waters can fish up to 12 NM from the coastline.

Maximum size for boats allowed to carry out fisheries within the baseline is $120 \mathrm{GT}$. A few shrimp trawlers larger than 120 GT have however specific licenses to fish within the baseline. There are also several small vessels operated outside of these two main quota systems i.e. the lumpfish fleet and many small unregistered dinghies, which are estimated to be around 1,500 in total. 
Figure 18: Greenlandic waters and the baseline where coastal vessels are allowed to fish within

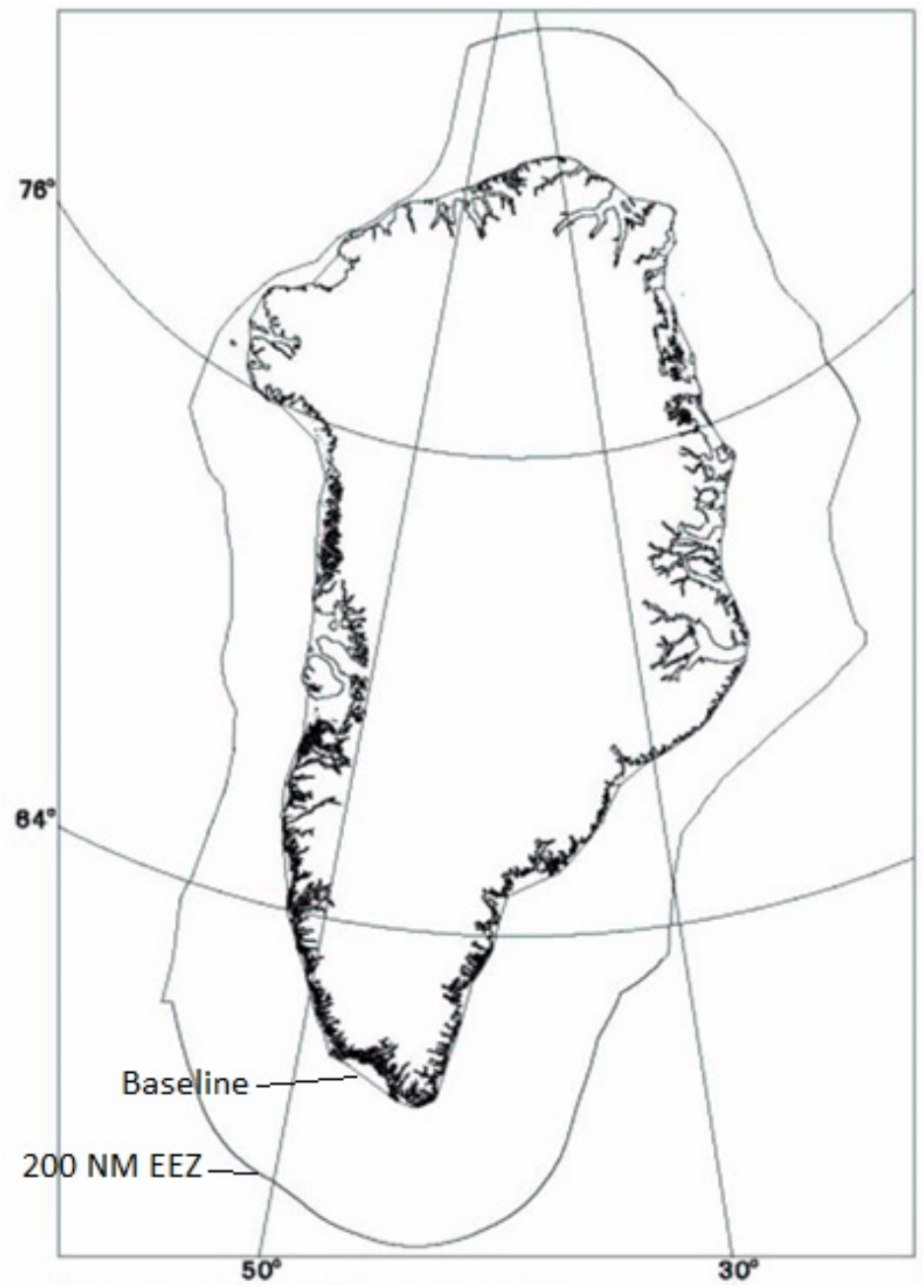

Estimating the total number of coastal fishermen in Greenland is not an easy task and involves considerable uncertainty, as registration is not obligatory for a big part of the fleet and many work only part time in the sector. The official number of people who has taken fishing, hunting and/or agriculture in Greenland as primary occupation in 2013 was 3,548 and when looking at people employed for at least one month in the sector the number was 6,819 (Statistics Greenland, 2014). Of the approximately 3,500 people working full time within fishing, hunting and agriculture industries, about 2,000 are estimated to be working in the coastal sector. The number of people working in the sector part time and for recreational purposes is much higher.

The operational environment for the Greenlandic coastal sector is difficult. For most species, there is a monopoly situation when it comes to selling the catch, resulting in prices often being extremely low. Logistics and transport issues make it difficult to get products to the market and to build up large scale industrialised processing in regions where coastal fisheries are of importance. Seasonality of the different fisheries further contributes to the problems of the coastal sector, making it difficult to provide 
sufficient income throughout the year. As prawn and Greenland halibut are by far the most important species regarding value, these fisheries are most likely to return profits. There are, however, only a handful of processers buying those catches and subsequently very few communities that have reported landings. The lumpfish fishery has given good returns during some seasons, but it is characterised by severe fluctuations due to unstable market situations. The initial investment to start a coastal fishery is relatively high and with low returns resulting from the prices paid for the fish, it is almost impossible to begin fishing in the Greenlandic coastal industry. Coupled with the overall reduction in number of vessels and consolidation of fisheries, this problem becomes increasingly difficult. The hope is however that the MSC certification for the lumpfish fishery will make it more stable and profitable. The cod fishery has for the most part been run with severe losses, but the increasing catches in the past 3-4 years and the hope for even higher catches in the near future are expected to make the cod fishery a profitable industry.

The coastal fleet is the backbone for employment and survival in many fishing settlements in Greenland, making the fleet extremely important for the survival of small fishing communities around the country. Landings from the coastal fleet are important for suppliers of fish for on-shore production, as it is mandatory for them to land all catches to on-shore processing plants. The costal fleet is largely operated from the cities situated on the ice-free coast, but the settlement patterns have been severely affected by the commercialisation of the fishing industry in the last decades. In some extreme cases, small traditional fishing settlements with little or no fishing rights have been forced to close their processing plants, either permanently or temporarily, causing severe problems regarding regional development. The shrimp industry has gone through an optimisation process, as the two largest seafood companies have aggregated the mainstay of the quota shares. By the turn of the century there were ten shrimp processing plants in the country, but today there are only four left, all located in the northern part of the country. Opportunities might be in further processing in some places, utilizing by-products and coming up with new and exciting products to export to national and international markets. The main challenge is however how dispersed the country is and how difficult logistical issues are. If it was not for the logistical challenges, there would be greater opportunities for processors to justify investment in processing facilities, if they could more easily source raw materials from different villages.

When looking at population development or migration over the past ten years, it is apparent that there is a trend where people are moving from smaller cities and settlements into the larger cities. There is also a clear trend showing that people from the larger cities are moving to the capital of Nuuk, and even from Nuuk to Copenhagen. The population in the cities is therefore growing, whilst population in the traditional fishing and hunting settlements around the country are decreasing. Young people seek education to the cities while the villages might not be able to provide them with those opportunities. It is unlikely that this progression can be stopped with more schools being placed away from the cities, this trend is therefore probably going to continue.

The coastal fleet serves an important role in the Greenlandic economy and regional development. The fleet, however, is for the most parts rather inefficient, with low 
average catches and challenging operational environment. The authorities have made some attempts to favour this fleet segment, which has helped the industry to some point. It is nevertheless difficult to start fresh in this business, because investment costs and capital costs are too high. It is likely that some parts of the coastal sector (prawn and Greenland halibut) will experience more consolidation in the nearest future, as has happened within the larger fleet. Fewer and better equipped vessels and economics of scale seem to be emphasised.

\subsection{Challenges and opportunities}

The Coastal fleet is extremely important for Greenlandic economy and regional development and amongst its main strengths is that it has a positive image, where high quality products are coming from clean seas. The connection of Greenland with the Arctic provides a competitive advantage in important markets.

There are though also significant weaknesses that the coastal fishery has to deal with, such as highly sensitive fish stocks with high fluctuations in catch volumes. The most important fishery, the shrimp fishery, has been in decline and the processing has been going through optimisation and there are only four processing plants left today. The operational environment for the coastal fleet is also a challenge, where the fishermen are obligated to sell their catches to on-shore processors that are not prepared to pay prices that the fishermen need to run a profitable business. The is also almost no new entry into the sector, as high investment and capital costs, coupled with low product prices, make it impossible for young fishermen to start their own business.

There are though also a number of opportunities within the Greenlandic coastal sector. The increasing cod stock is likely to provide significant opportunities for the coastal fleet. Better utilization of catches and processing of by-products is likely to present fishermen and processors with new opportunities. Product development by increasing the inland processing, creating innovating products and new jobs can as well boost the coastal sector. Improvements in processing facilities, increased optimisation, automation and better national- and international transportation of raw materials and final products can also provide opportunities in the near future.

The main threats are however that Greenland is dependent upon fishing as a source of income for small towns and sectors, whilst the overall trend is that people are moving away from smaller towns to larger cities and abroad. There is a danger of more consolidation within the coastal sector, which will have negative impact on regional development in the country. Some are also worried that the increase in cod catches might only be temporary, resulting in a danger of overfishing and depletion of the stock. 


\section{Iceland}

The coastal sector is hugely important for the Icelandic economy, particularly in rural areas where whole communities are dependent on the sector for survival. The sector accounts for $15 \%$ of the total landing value of the Icelandic fishing fleet and $21 \%$ of the demersal catches. Coastal catches are also important in supplying the processing sector with fresh fish that goes into added value products. The sector is therefore important on a number of fronts.

\subsection{The coastal fleet}

Just about 1,300 coastal fishing vessels were registered in Iceland in the beginning of year 2016 (Samgöngustofa, 2017), of which about 750 reported catches (The Icelandic Directorate of Fisheries, 2017). This fleet is highly diverse in respect to size, equipment and operations, but can be roughly divided into five main categories, which are interconnected:

1. Coastal vessels working within the (larger) ITQ system. There are about 150 vessels that reported catches within this vessel group in 2016. These vessels are of different sizes and operate with different fishing gear. The mainstay of the catches caught by this fleet were caught by vessels that are close to the upper limits of being categorised as coastal vessels. The main difference between vessels in this category and the other categories is that they can use variable fishing gear and many of them are fishing with gillnets for all or parts of the year.

Figure 19: Coastal vessel in the ITO system

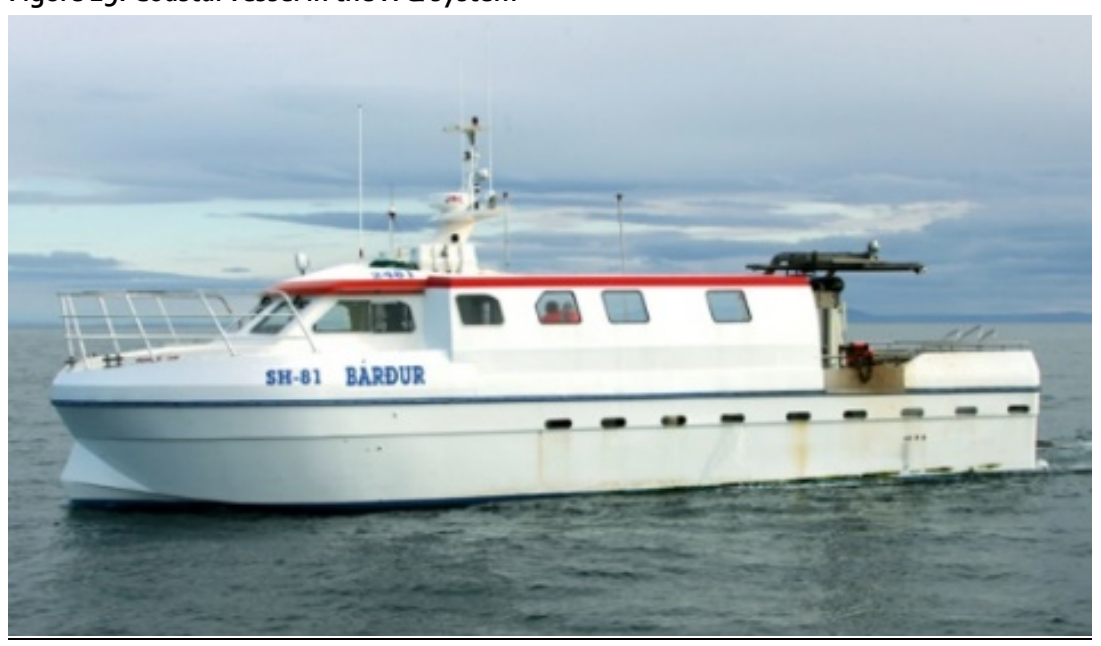


2. Coastal vessels working within the J\&L system. In 2016 there were just about 600 vessels that reported catches within this system. These vessels are solely allowed to use fishing gear with hooks, i.e. jigging and longline. Most of the vessels are modestly equipped longliners that are 8-12-meter-long and under 15 GT. The size distribution is caused by historic reasons, i.e. the upper limits used to be 12 meters, which then were expanded to 15 meters and $15 \mathrm{GT}$. Many of the best equipped vessels are therefore just under 12 meters and $15 \mathrm{GT}$, some of which have auto-line systems aboard. The upper limit was then raised again in June 2013 to 15 meters and $30 \mathrm{GT}$ and since then there have been at least twenty new vessels built/renovated that are close to this upper limit and a number of older vessels in this size category have also entered the J\&L system. This category spans a big diversity of vessels, from old style wooden jiggers to state-of-art fiberglass boats capable of reaching speeds in excess of 30 NM and operating 25 thousand hook auto-line systems.

Figure 20: Coastal vessel in the J\&L system

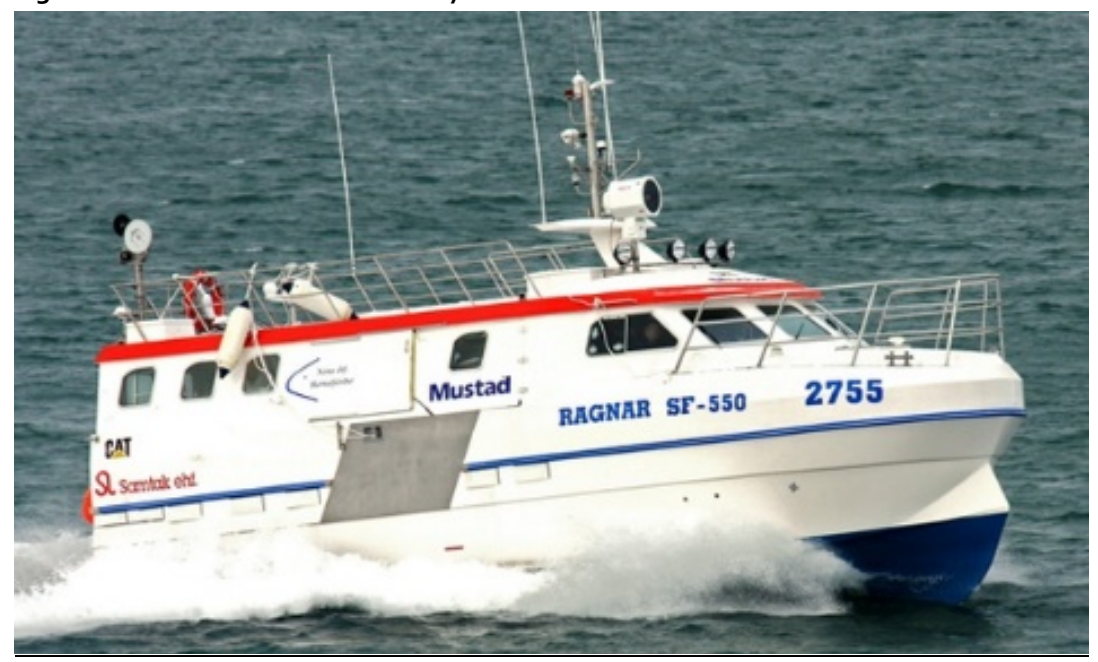

3. Coastal vessels in the coastal jigging system. Since 2009 the Ministry of Fisheries has allocated 4-9,000 MT quotas to coastal vessels that do not have quotas in other systems. The fishery is conducted as an Olympic fishery where TACs are set for each month (May-August) for each region (country split into four areas). Each vessel is only allowed to catch approximately $650 \mathrm{~kg}$ per day and once the TAC have been filled the fishery is suspended. The fishery is subjected to licensing and the aim of it is to provide newcomers with an opportunity to start in the business and to strengthen regional development. Despite its aim, vessels working in other systems can take part in the coastal jigging system, but cannot take part in two systems in the same month. The vessels taking part in the coastal jigging system are modestly equipped and the only fishing gear allowed are electrical/hydraulic jigging fixtures (maximum of four fixtures). In 2016 a total of 594 vessels took part in the fishery. 


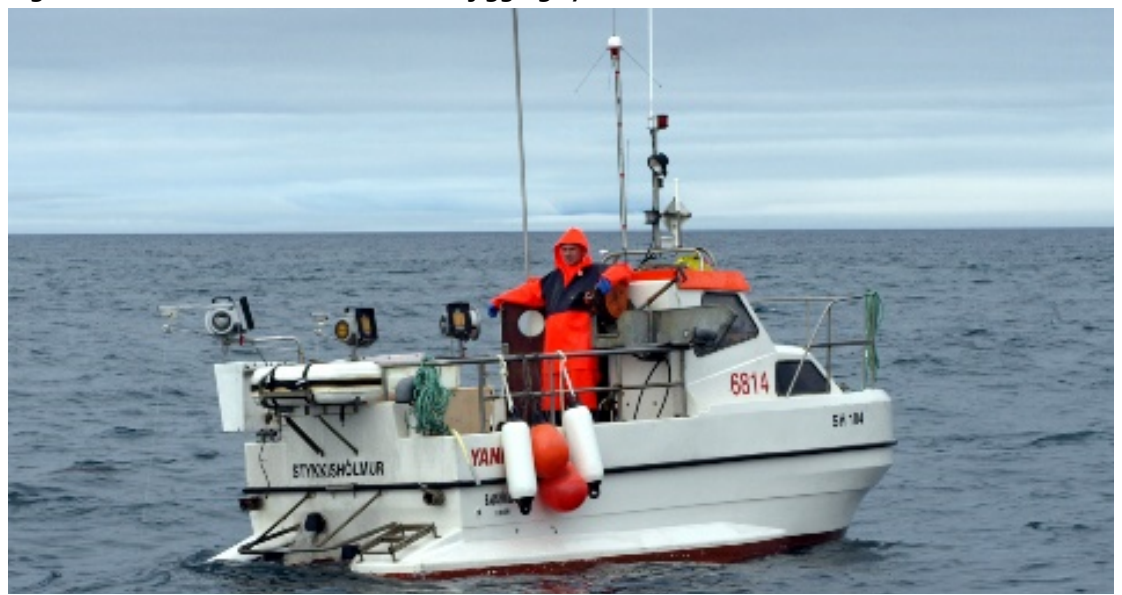

4. Coastal vessels in the Lumpfish fishery. Vessels operating within this system are generally basic gillnet vessels, which often take part in the J\&L system or the coastal jigging system when not fishing for lumpfish. There are over 400 vessels that can apply for a license each year, but participation varies depending on allocated effort quota (fishing days) and market conditions. In 2016 a total of 233 vessels used their lumpfish licenses. These lumpfish vessels are typically under 12 meters in length and not very technologically advanced.

Figure 22: Coastal vessel in the lumpfish fishery

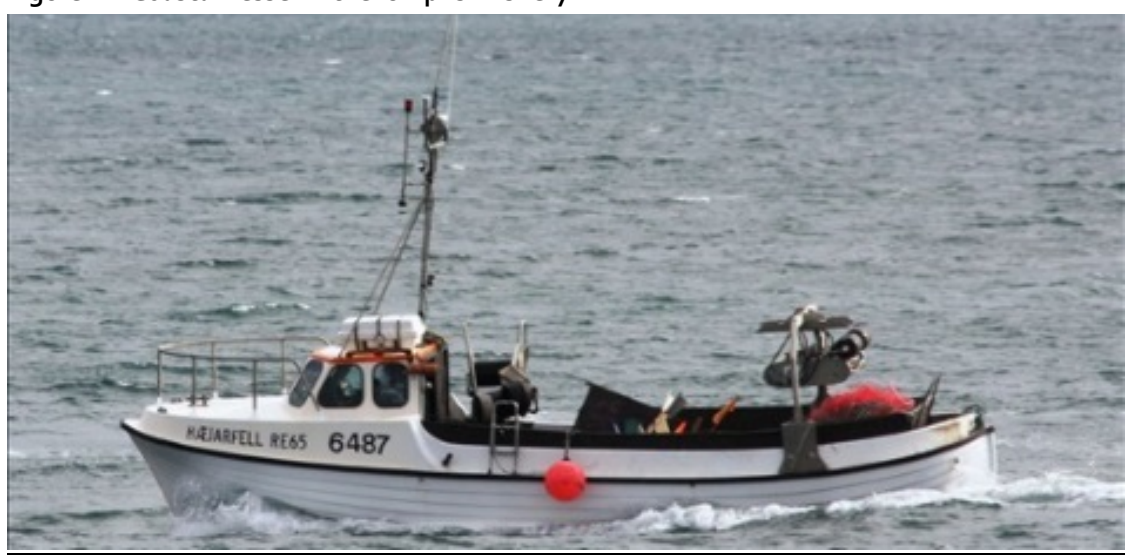

5. Leisure and tourist vessels. These are generally very basic open coastal vessels using either rod or jigging fixtures. When leisure fishing for own consumption, it is not allowed to use electric/hydraulic powered jigging fixtures. There are two alternatives available for these vessels, i.e. leisure fishing without quotas (maximum of seven fish a day) and leisure fishing within the J\&L system. In 2016 there were around 40 vessels registered for leisure/tourist fishing without quotas and similar number of tourist vessels within the J\&Ls. 
Figure 23: Leisure and tourist vessel

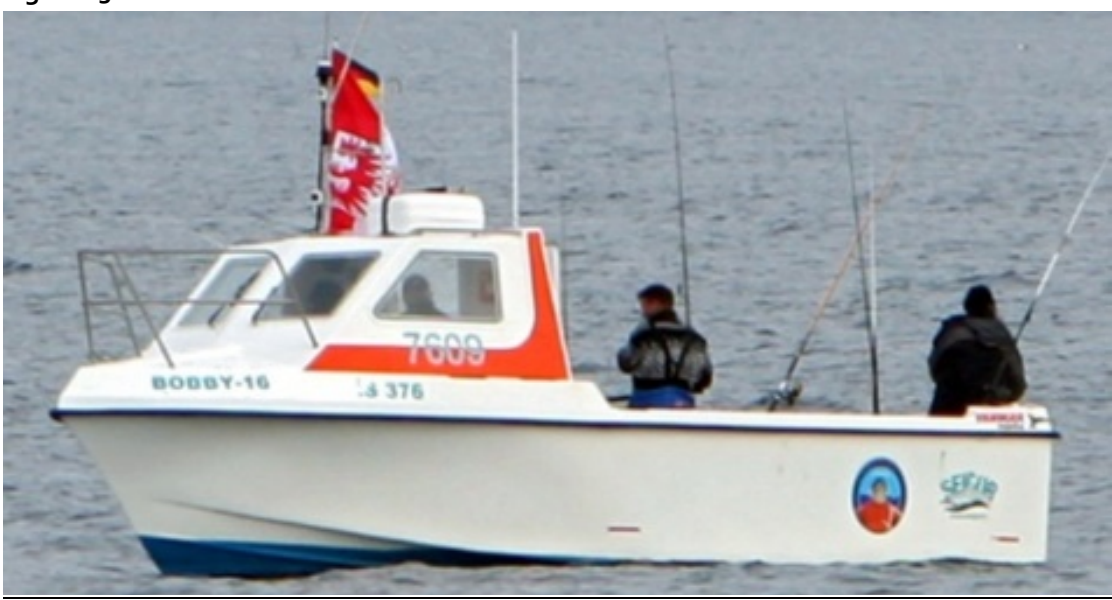

Table 6 shows the number of licenses allocated to coastal vessels in each category in 2017. It should be noted that some vessels are double counted, as they can work within more than one system within the year (Samgöngustofa, 2017), (The Icelandic Directorate of Fisheries, 2017).

Table 6: Number of each vessel-type working within the Icelandic coastal sector in 2017

Type of license/vessels reporting catches in 2013

Total number of registered fishing vessels / vessels reporting catches

Total number of "coastal vessels" / vessels reporting catches

Small vessels in ITQ system with permanent quota /

J\&L s with permanent $J \& L$ quota / vessels reporting catches

$277 / 609$

Coastal jigging system / vessels reporting catches

Lumpfish licenses / vessels reporting catches

$594 / 594$

Leisure fishing licenses

$400 / 233$

Tourist vessels with J\&Ls licenses

38

More than $80 \%$ of the coastal vessels are less than 10 meters in length and $95 \%$ are under 12 meters, as shown in Figure 24 (Samgöngustofa, 2017). 
Figure 24: Length distribution of the Icelandic coastal fleet

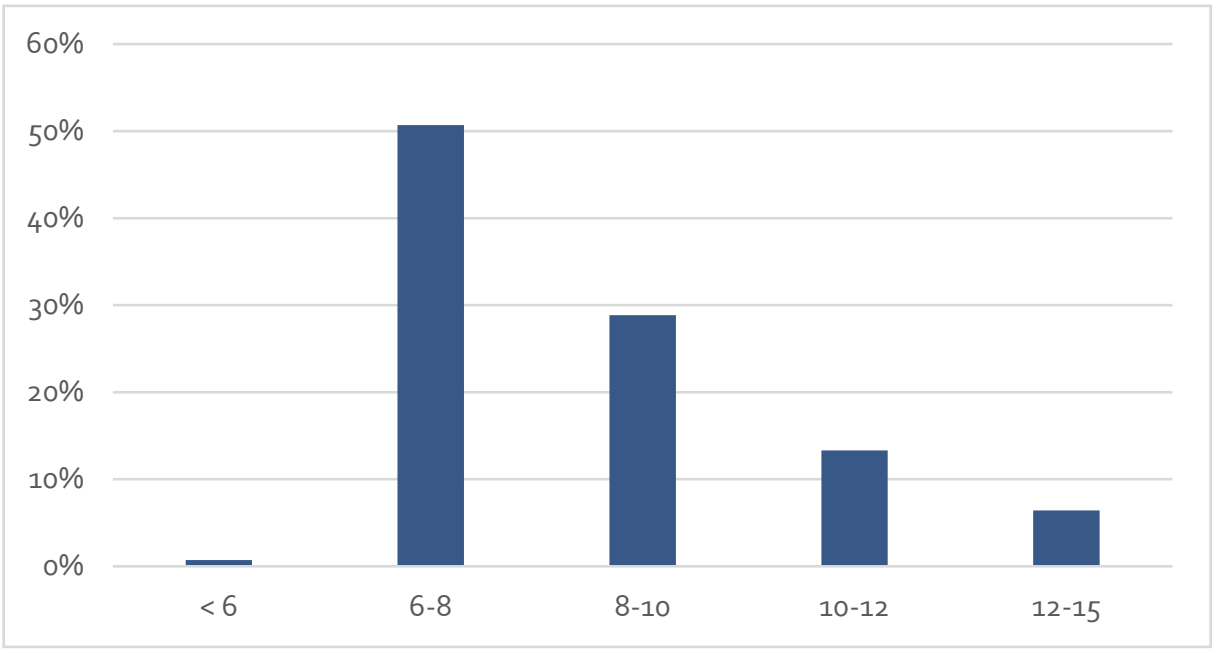

Over the past few years, the coastal fleet has seen a development towards the seafood companies buying up the quotas in the J\&L system and investing in larger and more technologically advanced vessels. This has resulted in smaller companies, operated by individuals, being forced to drop out and the sector becoming more industrialised.

\subsection{Catches and catch values}

The total catches of the coastal fleet amounted to 94 thousand tonnes in 2016, valued at EUR 152 million $^{4}$ (Statistics Iceland, 2017a). The J\&L vessels accounted for EUR 116 million (77\%) of the landing value, coastal vessels operating within the ITQ system accounted for EUR 19 million (12\%) and the coastal jiggers for EUR 17 million (11\%). The total landing value of the Icelandic fishing fleet was almost exactly EUR 1.o billion in 2016, which means that coastal catches accounted for $15 \%$ of the total landing value.

Cod was by far the most important species in the catches of the coastal fleet, accounting for $63 \%$ of the catch volume and $72 \%$ of the value, haddock was the second most important species accounting for $11 \%$ of the volume and $13 \%$ of the value. The vessels operating within the jig and line fishery accounted for $77 \%$ of the landing value within the coastal fishery, whilst the other two groups accounted for $12 \%$ and $11 \%$.

The coastal fleet is extremely important for the rural areas in Iceland, particularly areas that have been struggling in recent years. The West-Fjords, Western Iceland and communities in the north and east of Iceland depend on this fleet for survival. The value of coastal catches by fleet type, divided by regions is shown in Figure 25 (Statistics Iceland, 2017a). 
Figure 25: Total value in mill. EUR of the coastal fleet in Iceland in 2016 divided by regions

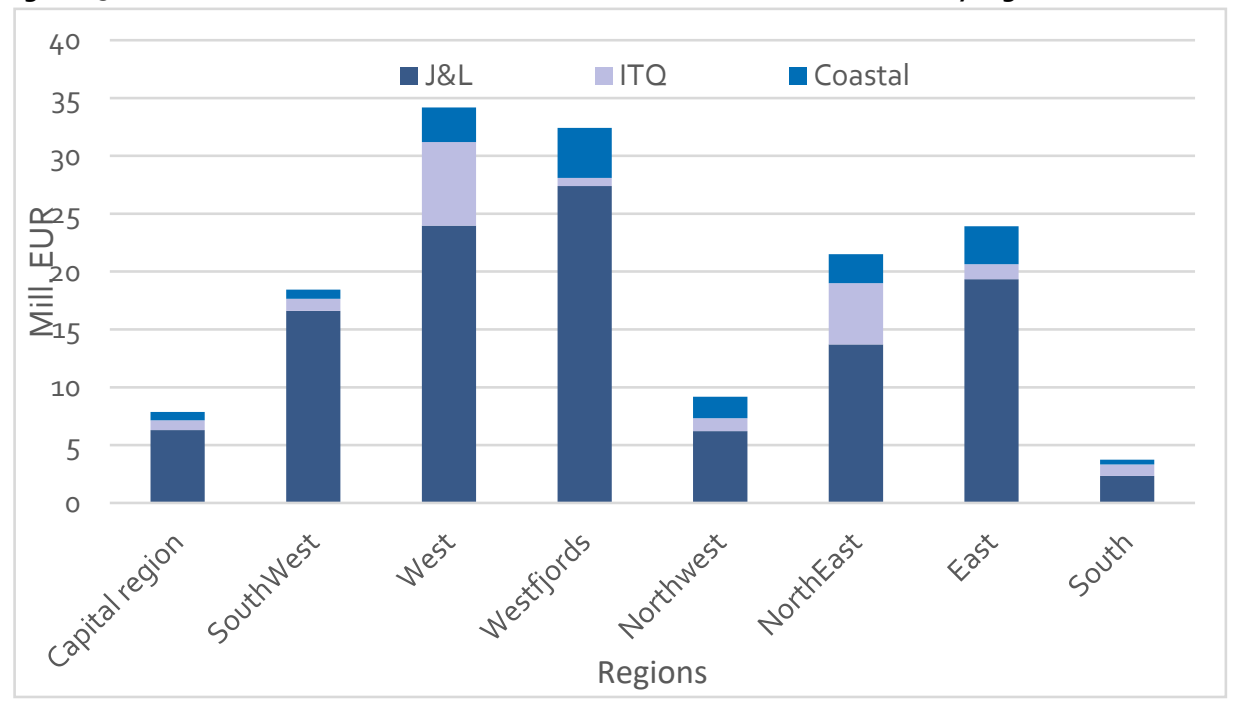

The coastal fleet accounted for $15 \%$ of the total landing value of the Icelandic fleet in 2016. The significance of the sector is though very different in each of the eight regions, where the coastal fleet accounted for example for $38 \%$ of the total landing value in the Westfjords, whilst it only accounted for $3 \%$ of the total landing value in the South of Iceland, as shown in Figur 26 (Statistics Iceland, 2017a).

Figure 26: Catch value by of the coastal fleet in comparison with the rest of the Icelandic fishing fleet in 2016

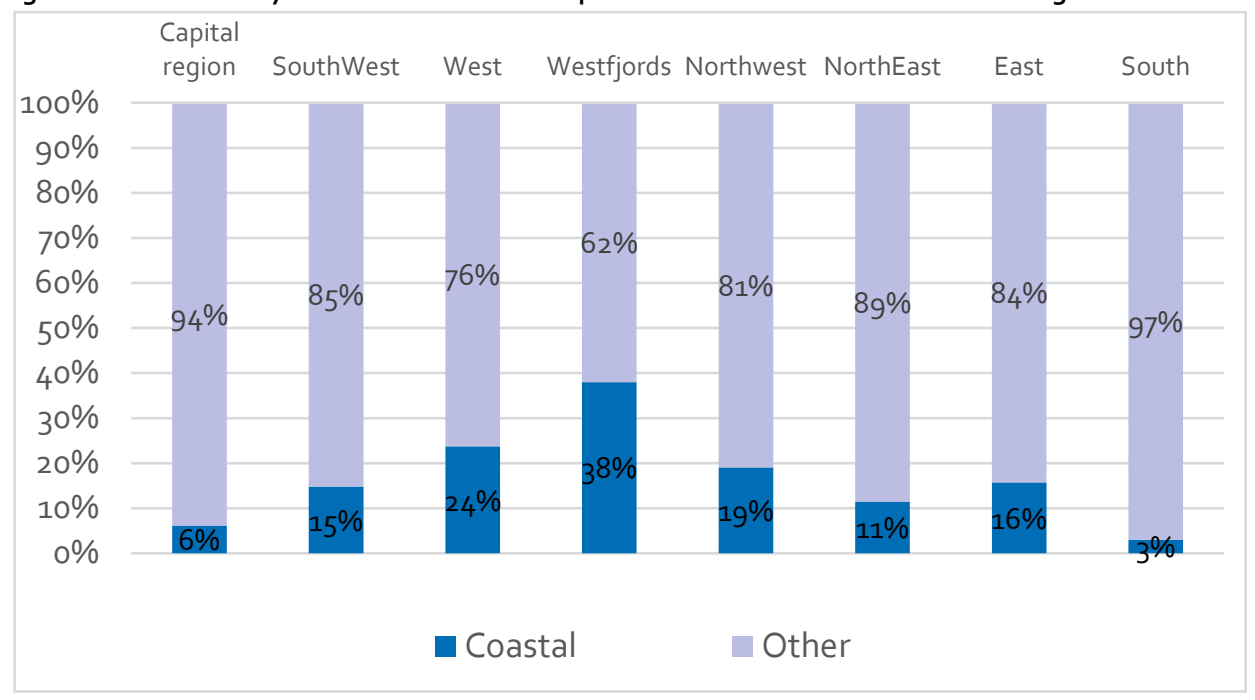

In 2010-2015, the wetfish trawlers generally presented the most profitable aspect of the Icelandic fishing industry, returning their owners $18.7 \%$ average Earnings Before Tax (EBT) of total earnings; as shown in Figur 27 (Statistics Iceland, 2017b). During the same period, vessels below $10 \mathrm{GT}$ were the least profitable sector, with an average EBT 
of only $1.8 \%$ of total earnings. According to this, it seems that governmental efforts tailored for smaller boats has not increased profitability among the smallest boats.

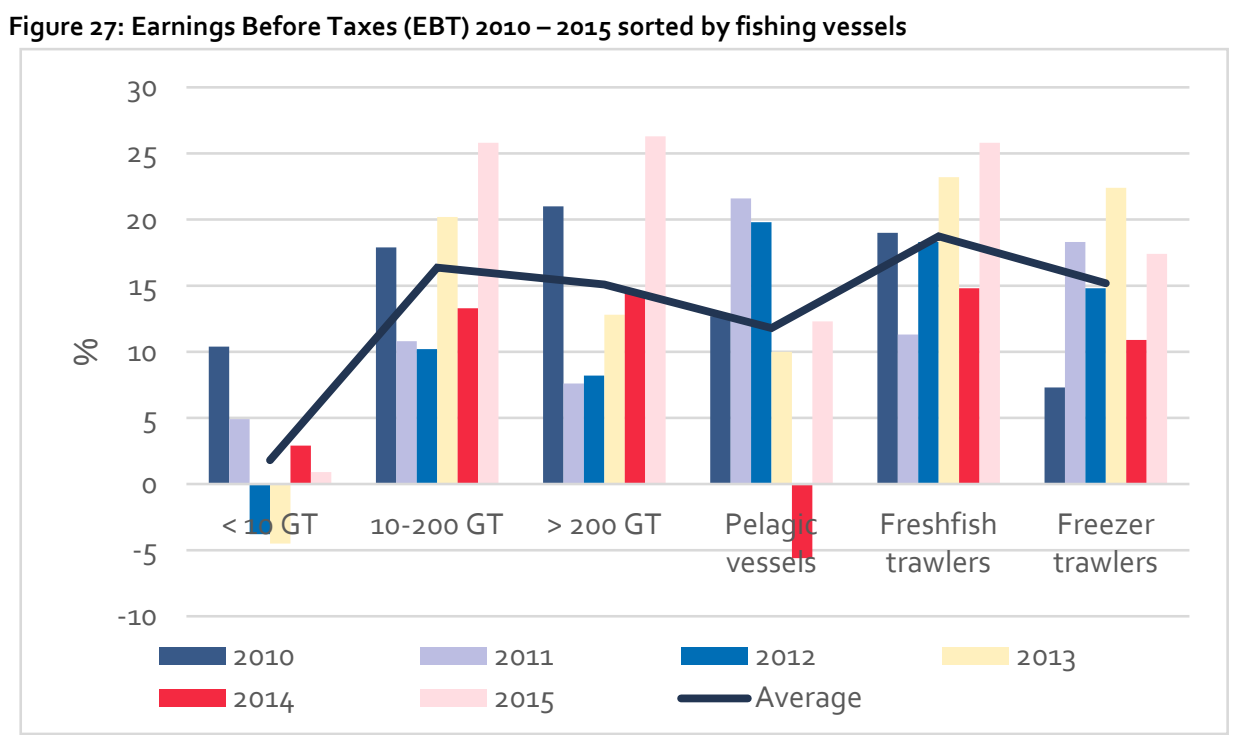

On average, the smaller vessels seem therefore to be not as economically efficient as other fleet segments. Table 7 shows the main cost items, as proportion of total income, for each of the fleet segments in the Icelandic fishery. It also shows EBITDA and EBT of the segments as proportion of total income (Statistics Iceland, 2017a).

Table 7: The main cost items and other key figures for the different fleet segments in Iceland

\begin{tabular}{lrrrrrr} 
& $\mathbf{1 0}$ GT & $\mathbf{1 0 - 2 0 0} \mathbf{G T}$ & $\mathbf{2 0 0} \mathbf{G T}$ & $\begin{array}{r}\text { Pelagic } \\
\text { vessels }\end{array}$ & $\begin{array}{r}\text { Freshfish } \\
\text { trawlers }\end{array}$ & $\begin{array}{r}\text { Freezer } \\
\text { trawlers }\end{array}$ \\
Wages & $25 \%$ & $31 \%$ & $35 \%$ & $30 \%$ & $35 \%$ & $41 \%$ \\
Oil & $9 \%$ & $7 \%$ & $5 \%$ & $12 \%$ & $9 \%$ & $10 \%$ \\
Fishing gear & $4 \%$ & $1 \%$ & $2 \%$ & $5 \%$ & $2 \%$ & $3 \%$ \\
Maintenance & $10 \%$ & $4 \%$ & $5 \%$ & $8 \%$ & $4 \%$ & $7 \%$ \\
Office cost & $9 \%$ & $5 \%$ & $3 \%$ & $4 \%$ & $3 \%$ & $4 \%$ \\
Insurance & $2 \%$ & $1 \%$ & $1 \%$ & $2 \%$ & $1 \%$ & $1 \%$ \\
Other costs & $5 \%$ & $3 \%$ & $4 \%$ & $2 \%$ & $5 \%$ & $7 \%$ \\
Total costs & $63 \%$ & $52 \%$ & $54 \%$ & $61 \%$ & $60 \%$ & $71 \%$ \\
EBITDA & $15 \%$ & $32 \%$ & $31 \%$ & $22 \%$ & $30 \%$ & $22 \%$ \\
Depreciation & $10 \%$ & $3 \%$ & $4 \%$ & $9 \%$ & $3 \%$ & $3 \%$ \\
Interests and infl. & $4 \%$ & $3 \%$ & $1 \%$ & $0 \%$ & $1 \%$ & $2 \%$ \\
Profits (EBT) & $1 \%$ & $26 \%$ & $26 \%$ & $12 \%$ & $26 \%$ & $17 \%$ \\
\hline
\end{tabular}

The figures suggest that the catching sector as a whole is highly profitable, with the exception of the coastal sector. It does though have to be taken into consideration that the coastal sector is extremely large and variable. Using average numbers may therefore be misleading, as some of the vessels may be bordering of being considered commercially operated. 


\subsection{Socioeconomic effects}

Research indicate that under the current fisheries management system, the fisheries sector has witnessed increased efficiency within the industry and decreased the cost of catching, due to several factors (Knútsson, Kristófersson, \& Gestsson, 2012). Companies have reduced their focus on achieving the highest volume and started focusing on maximizing the value created with better quality. Vertical integration of enterprises has increased in the industry and as results a massive economic optimisation has been achieved. One of the results is that quotas are being aggregated by larger seafood companies, as they have been buying out the smaller operators. In 1992 the ten largest quota holders owned $24 \%$ of the overall quota, but today the ten largest own 50\%; and the twenty largest quota holders own 69\% (Islandsbanki, 2016). The coastal sector has to a point been developing in the same direction, where the larger quota holders have been increasing their share in the J\&L quota, at the "expense" of smaller operators. In the beginning of the quota year 2017/18 the ten largest J\&L quota holders owned $37 \%$ of the total J\&L quota, and the twenty largest owned $55 \%$ (Icelandic Directorate of Fisheries, 2017). Studies have though shown that quotas have not on large scale been moved between regions, even though individual villages have in some cases lost big parts of their quotas (Agnarsson, Matthiasson, \& Giry, 2016). This indicates that spatial concentration has been much less than consolidation on a firm level; and that firms have mostly grown in size by merging with local firms or buying out smaller local operators.

The largest quota holders in both systems are vertically integrated seafood companies that are both taking part in the catching and processing links. This means that many of the coastal vessels are owned by processing companies, and all (or most) of the catches are processed by that same company. There is though also a large part of the coastal vessels that sell their catches through an auction system. This is a system that comprises of 27 fish markets across the country that are all connected to the same online auctioning system. The fish auctions are extremely important for the coastal sector, as they allow fishermen to sell their catches with minimum effort and for competitive prices. In fact, the prices on the auctions have on average been significantly higher than in direct sales. In 2016 the price paid at the auctions for gutted cod exceeded the prices in direct sales by $27.5 \%$ (Verðlagsstofa skiptaverðs, 2017).

It is estimated that approximately $50 \%$ of the value creation in the Icelandic seafood value chain occurs abroad, due to close cooperation across borders in order to obtain highest available price for the seafood products (Knútsson, Kristófersson, \& Gestsson, 2012). The difference between the revenue and the total cost of performing all the company's activities, provides the margin for each step in the value chain. The small vessel fleet is mainly harvesting and therefore only gets a small share of the value chain. There are a number of reasons for the low profitability of small vessels, but amongst them is the fact that the fishery is fluctuating due to different fish prices and sometimes unfavourable weather conditions, resulting in the small vessel fisheries being the least profitable sector of the Icelandic fishing fleet. 
During the 2oth century between 10 and 16 thousand people were employed in the fishing industry in Iceland. In 1930, $23 \%$ of the total workforce in Iceland worked in the fishing industry. In 2016, the contribution of the fishing industry to the total employment in Iceland was 4\%, with 4,000 employees working full time in the catching sector and 3,600 in the processing sector (Statistics Iceland, 2017c). The importance of the fishing sector is though highly variable, depending on the regions within Iceland. The fishing sector plays for example not a vital role in the capital area, whilst it is the backbone of job opportunities in other areas of the country. Figure 28 highlights this fact, as it reveals that $31 \%$ of the total production in the West-Fjords are within fisheries, whilst only $3 \%$ of the production in the capital area is in fisheries (Jóhannesson, Árnason, \& Sigurðsson, 2013).

Figure 28: Breakdown of production by sectors and regions in Iceland

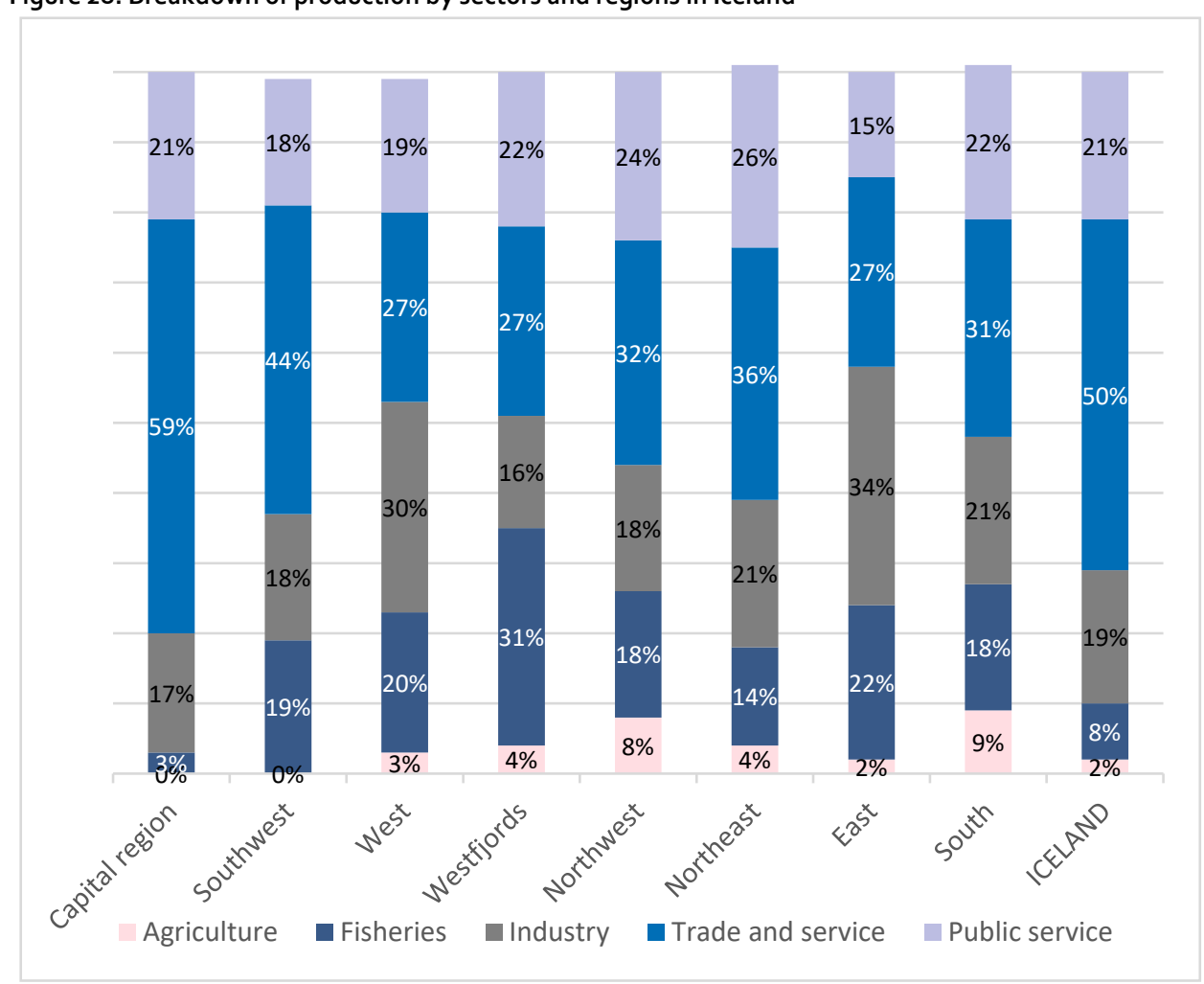

Low recruitment within the coastal sector has been an issue for concerns for some time, as young people seem uninterested in starting a career within the sector. There are a number of reasons for this, one of which is the aggregation of quotas that results in fewer and better equipped boats. Another explanation is that it is very difficult to begin as a vessel owner in this industry, as the initial investment cost is extremely high. Finally, the average wages in the coastal sector do not match up with the average wages in other fishing sectors, as shown in Table 8. (Viðarsson, Sigurðardottir, \& Sveinpórsdóttir, 2016). 
Manufacturing

Electricity, gas, steam, and air conditioning supply

Water supply; sewerage, waste management etc.

48,522

Construction

Wholesale and retail trade; repair of motor vehicles

The average wages within the coastal sector are therefore similar to for example manufacturing and construction on-land, but much lower than in fisheries within other fleet categories.

From 1998 until 2017 population growth in the capital area was 31.8\%, whereas population in the West-Fjords declined by $19.7 \%$ (Byggðastofnun, 2017). The most important reasons for relocation have been found to be education, job variation and higher salaries in urban areas than in rural areas (Gunnarsdóttir, 2009). Previously homogeneous job opportunities, limited options of recreation and bad transport conditions had been identified as factors in decline in population in rural Iceland (Jóhannesson B. , 1998). Job opportunities in general must also be an important factor and the fact is that in many of the coastal communities around Iceland rely heavily on coastal fisheries. The coastal fishery provides raw material for the processing and most of the servicing industry in these communities are then in one way or another supporting the fishing industry. Without a strong coastal sector, the communities will struggle even more to survive.

The Icelandic fisheries management Act has three main objectives, which are to ensure sustainable utilisation of fish stocks that contribute to a profitable industry, while providing jobs that support stable settlement in the country. The quota system has been quite successful in regard to the first two objectives, but the third objective has to a large degree been sacrificed to achieve the other two objectives. The government has though provided the coastal sector with opportunities that are meant to favour that fleet segment above other segments; partly because the coastal fleet is believed to be important when it comes to providing jobs that support stable settlement in the country. Amongst these are:

- The coastal jigging system: The aim of the system is to provide newcomers with an opportunity to start out in the industry and to strengthen regional development. The average fisherman's wage during the coastal jigging season is however not sufficient to support a fisherman for the whole year. In 2013 for example, the average total landing value of coastal jiggers were approximately 6,000 
EUR/month, which then must cover investment- and operating cost, in addition to providing the owner with acceptable salaries (Pálsson, 2014). Fishermen can however use costal jigging to supplement other fisheries. There are some examples of fishermen that combine fishing lumpfish and coastal fishing with reasonable success.

- The long-line concession: The objective of long-line concession is to create more jobs in coastal communities, as long-lining boats that incorporated manual labour in applying bait on hooks receive the concession, unlike boats that used machines to apply bait on board the boats. Its contribution to regional development is debatable as the profitability of the long-line concession depends on the number of hooks used to catch the $20 \%$ "surplus of quota" which is allocated to long-line concession, as the more hooks used to catch the quota, the less the profitability is. Some boats have been successful using the long-line concession but others have not and the amount of boats has decreased since establishment of the system (Agnarsson, 2012).

- Regional quota for struggling coastal communities: In the years 2003-2004, the Icelandic government first allocated regional quota specifically for coastal communities. This quota is assigned to communities that are dependent on fishing or fish processing and have suffered a decline in fisheries. How much quota is allocated to each region/community is based on statistical calculations on fish depletion and reduction in processing. Conditions regarding the landing of fish for processing in the region are attached to this quota, in order to ensure that as much value as possible stays in the community that is allocated this quota. Like with any other form of quota allocations in Iceland, the quota must be assigned to vessels, which means that boat owners must submit a request to the municipal asking for a permit to fish the regional quota and commit to fulfil requirements made by that municipality on landing and location of processing. The regional quota has been the lifeline of some coastal communities, but it has also caused an uproar regarding the qualifications of the ones that do get to fish the quota.

The coastal fleet serves an important role in the regional development, as well as for the Icelandic economy, in terms of safeguarding employment in vulnerable communities. The regional quota and the coastal jigging system were both established to enable smaller communities to maintain their fishing industry, which, in most areas, was and is the foundation of the community. Scholars have pointed out, that what coastal communities need most of all in order to grow and meet demands and expectation of inhabitants, is stability and sustainability (Bjarnason, 2012). In stable circumstances, companies should be able to invest for the long run and make long term commitments. Communities that depend heavily on fisheries, seafood processing and supporting industries should also be able to adapt to those commitments with longer notice. Under the current situation, it seems as regional quota and the coastal jigging line system are unstable, and that these schemes can hardly be counted as future systems for the communities. As regional quotas are offered/auctioned out annually, it is difficult for companies to plan, not knowing the total quota share at the beginning of 
the year. Coastal communities would benefit more from a stable management with measures set for longer time periods than the current system does.

As the processing sector relies more and more on automated processing equipment, the need for higher volumes of raw material increases, thus the economy of scale in fish processing is becoming much more important than before. In order to sustain fish processing on land, a stability in quota allocations is also of increasing importance. Research show no statistical connection between regional quota and landed fish, regional quota and amount of processed fish, or regional quota and catch in any of the coastal communities which have been allocated regional quota (Sveinn Agnarsson \& Vífill Karlsson, 2015). Provisions are included in the current legislation on regional quota which obliges the catch to be processed in the region that has the quota. Only the long line concession seems to have had positive effects on landed and processed catch (Sveinn Agnarsson \& Vífill Karlsson, 2015).

Leisure fishing or sea angling is becoming more and more popular as a tourist attraction in some coastal communities in Iceland; particularly in the Westfjords. This kind of tourism has been available for over a decade now and is quite popular among European tourists; mostly middle-aged men, who come to Iceland for its unique fishing grounds and availability of big fishes. In some places, like Suðureyri in Súgandafjörður, tourism has grown in the last decade, largely due to the coastal fishing and the image of the fishing village, which offers unique fish related experiences for the tourist. This includes a tour of the fish factory, seafood dinner at the restaurant, seeing fish swimming in the village pond, etc. Due to this development, Suðureyri has become one of the most popular attractions in the Westfjord area, jut for being what they are; a small fishing community in the North Atlantic.

\subsection{Challenges and opportunities}

The main strengths of the Icelandic coastal fishery are its image and heritage, along with highly technologically advanced fleet. The coastal fishery is mainly operated from small coastal communities that are situated close to good fishing grounds that have been utilised by small-scale fishermen for generations. The fish stocks are in healthy condition, the fishery is (for the most parts) profitable, the communities are built up around the fisheries and this all makes a good story to tell consumers. It is also a big strength of the coastal fishery that its supply is primarily going into production of the more valuable seafood products, such as fresh fillets and portions. The fish auction markets present also an important strength for the coastal fleet, as they enable fishermen to sell their catches regardless of where they land; and provide them with competitive prices. The fish auctions do also provide processors in coastal communities the opportunity to source fresh fish on daily basis. The coastal fishery has the support of the government and majority of the population, because of its image, importance for regional development and because of relatively low environmental impacts. The fact that the coastal fleet uses static fishing gear that causes minimum impact on the seabed, there are very little by-catches, accidental catches of seabird are negligible and 
the ratio between fuel usage and catch volumes are amongst the lowest recorded are amongst the many strengths of the coastal fishery. It can also be considered as a strength that lines of communication within coastal communities are short, so that decisions can be taken quickly.

The most significant weaknesses of the coastal fishery are its low profitability, compared to other fleet segments. Low wages in comparison with other fishermen. Instability where the vessels may not be able to go to sea for weeks at a time, because of weather. Low recruitment in the sector. The high variability in the quality of coastal catches presents a weakness as well. These small vessels do simply not have the necessary space or equipment to ensure correct on-board handling. When it comes to the weaknesses of the coastal communities themselves, the most severe weaknesses are caused by the monotonous economy, where there are few job opportunities for educated people and in particular for women. Opportunities for education are scarce and younger people are therefore likely to leave these communities. Another weakens of coastal communities in Iceland are difficulties with transportation, as many of the fishing villages become poorly connected to the outside world during parts of the winter.

There are opportunities for the coastal fleet to gain competitive advantage for their catches, as they have an extremely good story to tell. Marketing of seafood is changing, where the whole experience is becoming a part of the meal, in high paying niche markets. There are also young fishermen that are interested in starting their own business, but the investment cost is too high for them - which means that there are opportunities there if the authorities are ready to invest in them. There are definite opportunities in tourism for the coastal vessels and the communities, as for example sea angling, bird watching, whale watching and seal watching can present new options.

The most significant threats that the coastal fishery has to deal with is that the authorities will not support them as needed and that fishermen will leave the sector to work on other vessels that pay higher wages. The main threat for the coastal communities is that all of the younger people will move out, due to better quality of life in larger cities. 



\section{Norway}

Norway's marine fishery sector can roughly be divided into the coastal sector and the offshore sector. The coastal sector is dominated by smaller vessels manned by $1-5$ persons, while the offshore sector consists of larger vessels with a crew of up to 20 persons or more. About $25 \%$ of the overall TAC is allocated to the coastal sector and $70 \%$ of the TAC in cod.

\subsection{The coastal fleet}

The definition of a Norwegian coastal vessel applies to fishing boats that are less than 21 meters in length and 500 cubic meter hull capacity. The coastal sector included 5,583 vessels in 2016, of which $86 \%$ were less than 11 meters long (The Norwegian Directorate of Fisheries, 2017). The bulk of these vessels are in Northern Norway, where $57 \%$ of the coastal fleet is located. Only $3 \%$ of the coastal fleet are vessels over 15 meters, of which $75 \%$ are in North Norway. All coastal vessels need to have the owners on-board the vessels and processors are not allowed to own vessels, resulting in the sector consisting of a lot of one-man companies. The regional distribution seen in the Norwegian coastal fleet (Figure 29) is a result of tradition, closeness to fishing grounds and political favouritism towards coastal fisheries in Northern Norway.

Figure 29: Regional distribution of the Norwegian coastal fleet in 2012

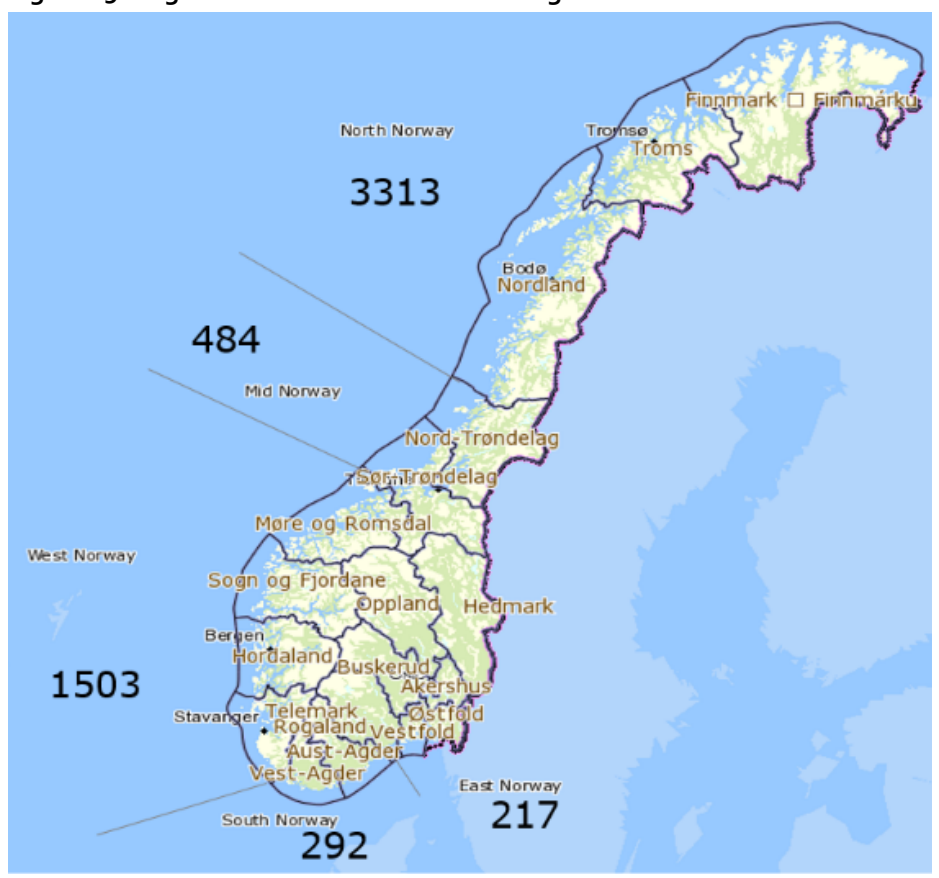


Table 9 demonstrates size- and regional distribution of Norwegian coastal vessels in 2012 (Henriksen, 2014).

Table 9: Size and regional distribution of the norwegian coastal fleet in 2012

\begin{tabular}{lrrrr} 
Region & $<\mathbf{1 1} \mathrm{m}$ & $\mathbf{1 1 - 1 5} \mathrm{m}$ & $\mathbf{1 5 - 2 1} \mathbf{~}$ & Total \\
North Norway & 2,729 & 452 & 132 & 3,313 \\
Mid Norway & 417 & 62 & 5 & 484 \\
West Norway & 1,316 & 35 & 32 & 1,503 \\
South Norway & 252 & 32 & 8 & 292 \\
East Norway & 188 & 28 & 1 & 217 \\
Total & 4,902 & 729 & 178 & 5,809 \\
\hline
\end{tabular}

The coastal fleet is divided into three different length groups, which after the last revision are divided into the following length spans: < 11 meters, 11-14.99 meters, 1520.99 meters and 15 meters up to 500 cubic meter hull capacity. About $75 \%$ of the coastal vessels are made of fiberglass, but as can be seen in Table 10 there is quite a difference in hull material depending on vessel size. About $64 \%$ of coastal vessels over 15 meters are made of wood and $21 \%$ are made of steel, whilst the overwhelming majority of vessels under 15 meters in length are made of fiberglass (Henriksen, 2014).

Table 10: Hull material depending on size group in the Norwegian coastal sector 2012

\begin{tabular}{lrrrr} 
Hull Material / length group & $<\mathbf{1 1} \mathbf{~ m}$ & $\mathbf{1 1 - 1 5} \mathbf{~}$ & $\mathbf{1 5 - 2 1 ~} \mathbf{m}$ & Total \\
GRP & 3,790 & 452 & 26 & 4,268 \\
Wood & 1,063 & 214 & 114 & 1,391 \\
Steel & 46 & 63 & 38 & 147 \\
Total & 4,899 & 729 & 178 & 5,806 \\
\hline
\end{tabular}

Most of the vessels have modest engine power, but average engine size in the $<11 \mathrm{~m}$ fleet is $121 \mathrm{HP}$, in the 11-15-meter fleet it is $277 \mathrm{HP}$ and in the over 15-meter fleet it is $402 \mathrm{HP}$. The fleet is quite old and there have not been any dramatic investments within the fleet since the 80 s. About $75 \%$ of the fleet is over 20 years old, as shown in Table 11 . It should though be pointed out that $18 \%$ of the fleet is built after the year 2000 .

Table 11: Age of the Norwegian coastal sector according to length groups

\begin{tabular}{lrrrrr} 
Year of construction & $<\mathbf{1 1} \mathbf{~ m}$ & $\mathbf{1 1 - 1 5} \mathbf{~ m}$ & $\mathbf{1 5 - 2 1 ~} \mathbf{m}$ & Total & $\%$ \\
Before 1960 & 133 & 53 & 21 & 207 & $4 \%$ \\
$1960-69$ & 219 & 47 & 35 & 301 & $5 \%$ \\
$1970-74$ & 425 & 15 & 17 & 457 & $8 \%$ \\
$1975-79$ & 844 & 77 & 26 & 947 & $16 \%$ \\
$1980-84$ & 1,065 & 93 & 17 & 1,175 & $20 \%$ \\
$1985-89$ & 806 & 149 & 36 & 991 & $17 \%$ \\
$1990-94$ & 266 & 66 & 6 & 338 & $6 \%$ \\
$1995-99$ & 263 & 89 & 13 & 365 & $6 \%$ \\
$2000-04$ & 308 & 70 & 3 & 381 & $7 \%$ \\
$2005-09$ & 385 & 54 & 4 & 443 & $8 \%$ \\
$2010-12$ & 185 & 16 & 0 & 201 & $3 \%$ \\
Total & 4,899 & 729 & 178 & 5,806 & $100 \%$ \\
\hline
\end{tabular}


The total number of coastal vessels has been decreasing over the past few decades, primarily in the smallest size group. Since 1995 the number of coastal vessels has decreased by a total of $60 \%$ and in the past decade the number has reduced by $18 \%$, as shown in Figure 30.

Figure 30: The total number of coastal vessels under 21 meters, broken into four categories

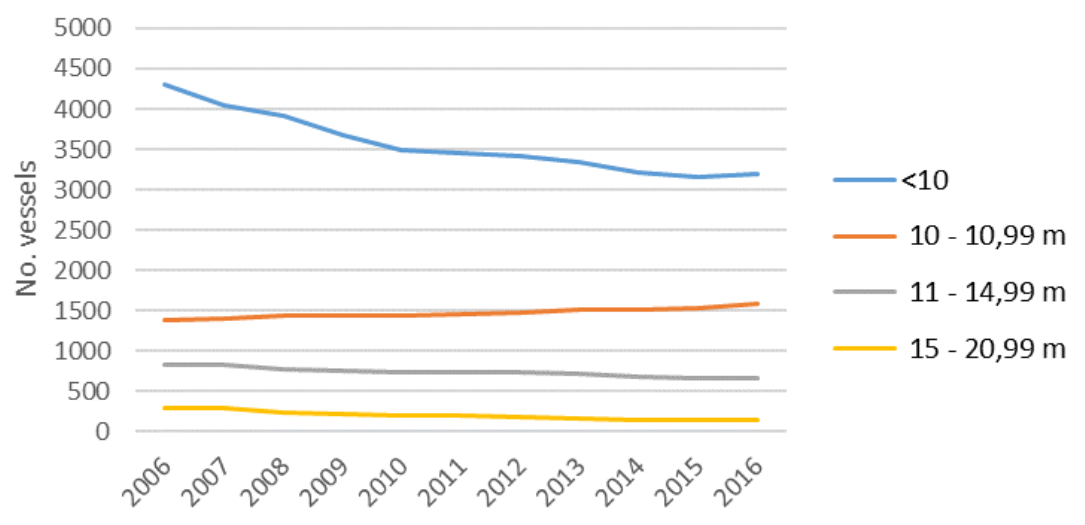

Most of the Norwegian coastal vessels are gillnetters or Danish seiners, but these two types of fishing gear accounted for $55 \%$ of total coastal catches in 2013 and $72 \%$ of the coastal cod catches (The Norwegian directorate of fisheries, 2014b).

\subsection{Catches and catch values}

The coastal fleet of Norway landed in total just over 400 thousand tonnes in 2015, valued at EUR 550 million $^{5}$ (Norwegian Directorate of Fisheries, 2017). The most valuable species for the fleet segments under 21 meters is cod, but other important species are haddock, pollock and herring; as shown in Figure 31.

5 The $21-28$ meter size group is included in these numbers. 
Figure 31: Distribution of species caught by fleet segments under 21 meters and summarized revenue for each species

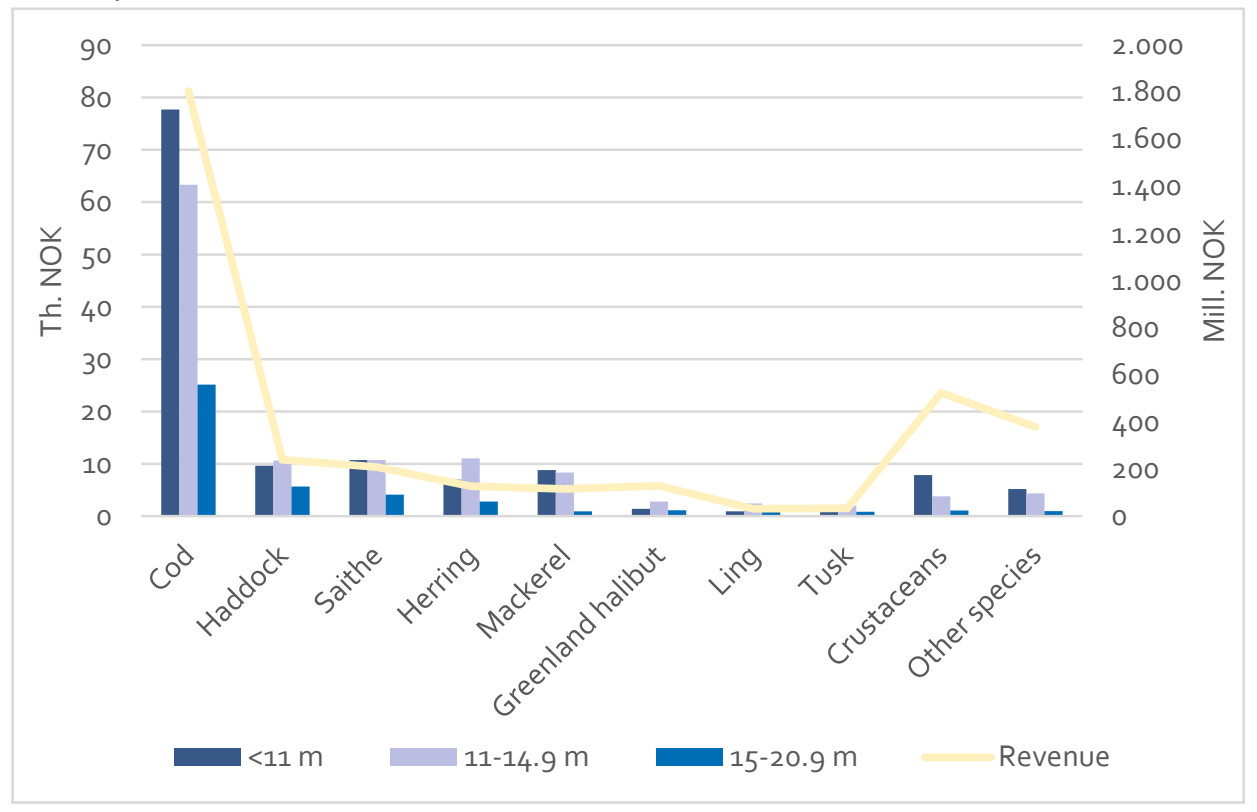

Majority of the coastal catches are landed in Northern- and western Norway, with more than $2 / 3$ being landed in Northern Norway. Figure 32 shows the proportion of landed catches in each region in 2013 .

Figure 32: Landings of Norwegian coastal catches in 2013 by regions in volume

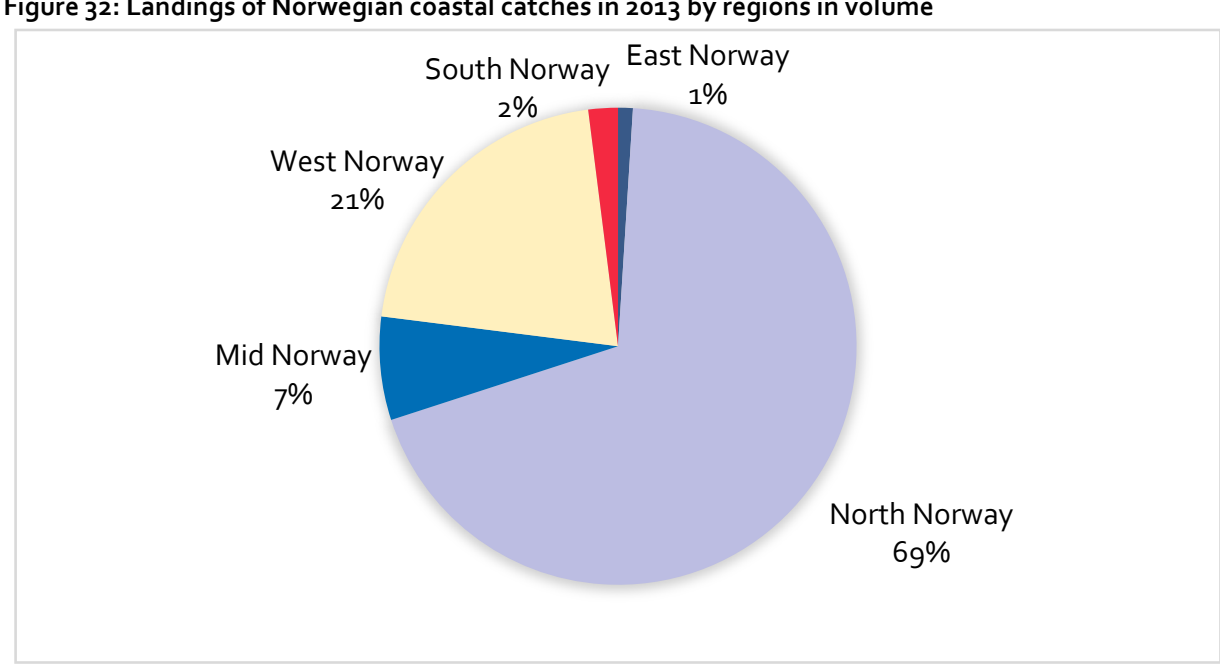

Over half of the total caught species are landed by Danish seine or gillnets, as shown in Figure 33. Compared to other Nordic coastal fleets, this number is quite unusual. Line and purse seine are also important fishing gears in Norway, having the total of $16 \%$ and $13 \%$ of landing volumes, respectively. 
Figure 33: Distribution on Norwegian coastal catches by fishing gear in 2013

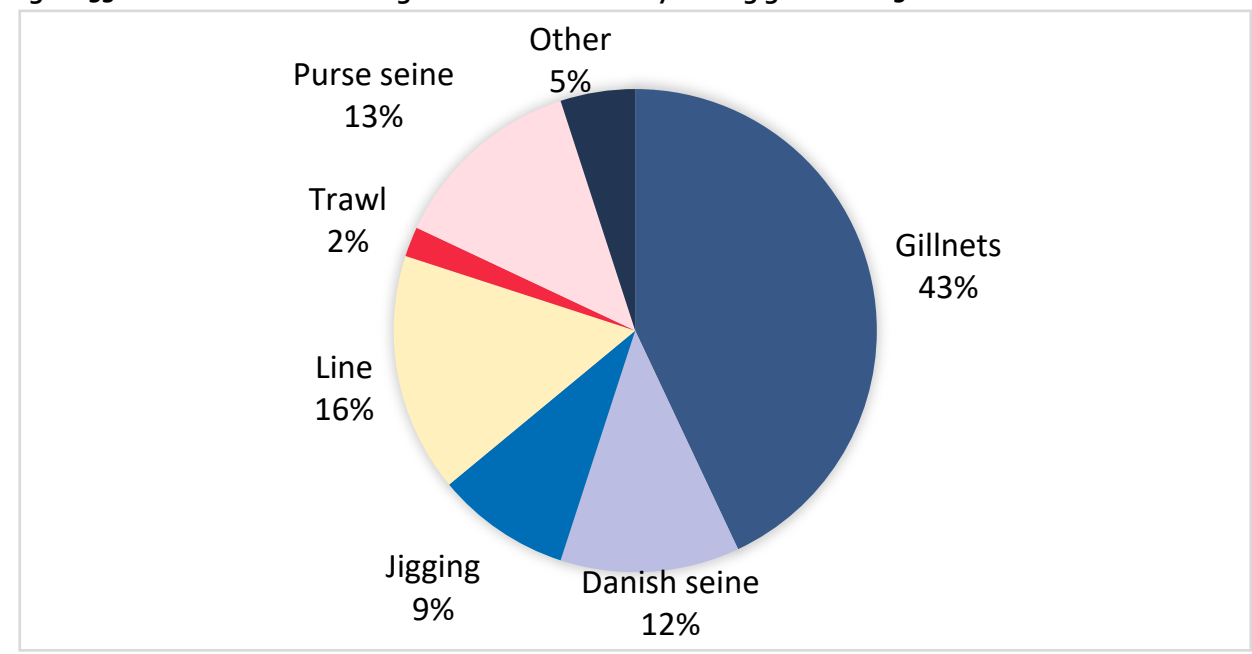

The coastal fleet as a whole is returning profits, as the average coastal vessel is returning 517 thousand NOK (55,000 EUR) profits, which is a $13.7 \%$ operating margin. Table 12 shows the operating profits and expenses, as well as the operating margin for the specific fleet segments. The first two lines compare the coastal vessels in general to ocean-going vessels, but a higher operating margin can be seen for the latter. The coastal vessels are also broken into two categories in the table i.e. sub-11 meter boats and boats between 11 and 28 meters.

Table 12: Operating profit and profit on ordinary activities before taxation in 2015. Average per vessel

\begin{tabular}{lrrrrrrr} 
& $\begin{array}{r}\text { Operating } \\
\text { revenues } \\
\text { NOK }\end{array}$ & $\begin{array}{r}\text { Operating } \\
\text { expenses } \\
\text { NOK }\end{array}$ & $\begin{array}{r}\text { Operating } \\
\text { profit } \\
\text { NOK }\end{array}$ & $\begin{array}{r}\text { Operating } \\
\text { margin }\end{array}$ & $\begin{array}{r}\text { Profit on ordinary } \\
\text { activities before } \\
\text { taxation NOK }\end{array}$ & $\begin{array}{r}\text { No. of vessels in } \\
\text { the population }\end{array}$ & $\begin{array}{r}\text { No. of } \\
\text { vessels in } \\
\text { sample }\end{array}$ \\
\hline $\begin{array}{l}\text { Coastal vessels } \\
\text { (all sizes) }\end{array}$ & $3,779,200$ & $3,262,200$ & 517,000 & $13.7 \%$ & 290,200 & 1,516 & 213 \\
$\begin{array}{l}\text { Ocean-going } \\
\text { vessels (all sizes) } \\
<11 \mathrm{~m}\end{array}$ & $63,405,000$ & $49,926,400$ & $13,478,600$ & $21 \%$ & $8,076,700$ & 156 & 119 \\
\hline $11-27,9 \mathrm{~m}$ & $1,322,600$ & $1,176,800$ & 145.700 & $11.0 \%$ & 118,000 & 845 & 59 \\
\hline & $4,827,200$ & $4,207,800$ & 619.400 & $12.8 \%$ & 351,000 & 594 & 131 \\
\hline
\end{tabular}

The operating margins are similar for both coastal fleet segments, but the operating profits for the smaller vessels is though only 15 thousand EUR, which could make it difficult to profit from those operations, especially when initial investments are high. This might affect the decision making in the future development of this fleet category. 


\subsection{Socioeconomic effects}

Fishermen in Norway are around 12 thousand in total, of which 9 thousand have fisheries as their main source of income (Henriksen, 2014). In 1960, a total of 50 thousand people worked as fishermen in Norway and the numbers have been decreasing steadily ever since. The number of vessels has also decreased significantly in recent years, particularly in the coastal fleet. Despite it being relatively easy to start up a new business in the coastal sector, new entry has been lacking. Investment in new boats and quotas are costly. Another reason is probably competition from other industries that can pay higher wages and offer better working conditions. The seasonality of the fishery is also a factor, since many coastal vessels are only operated for parts of the year.

The number of full time employment (e) man-years in the coastal sector has been decreasing. Between the years 2002 and 2012 the number of FTE in the coastal demersal sector decreased by almost $16 \%$, which is a similar trend as has been going on in many other fishing sectors, as can be seen in Table 13 (The Norwegian directorate of fisheries, 2004) \& (The Norwegian directorate of fisheries, 2013).

Table 13: Number of full time employment man-years in the Norwegian fishing fleet 2002 and 2012 by fleet type

\begin{tabular}{|c|c|c|c|}
\hline Fleet/year & 2002 & 2012 & Difference \\
\hline Demersal coastal vessels <11 m & 2,961 & 824 & $-15,6 \%$ \\
\hline Demersal coastal vessels 11-14.9 m & 2,961 & 850 & $-15,6 \%$ \\
\hline Demersal coastal vessels 15-20.9 m & 2,961 & 826 & $-15,6 \%$ \\
\hline Conventional "coastal vessels" >21 m & 2,100 & 329 & $-36 \%$ \\
\hline Conventional deep-sea vessels & 2,100 & 1,008 & $-36 \%$ \\
\hline Cod trawlers & 1,340 & 1,439 & $7 \%$ \\
\hline Shrimp trawlers & 535 & 263 & $-51 \%$ \\
\hline Pelagic coastal vessels $<11 \mathrm{~m}$ & 44 & 99 & $125 \%$ \\
\hline Pelagic coastal vessels $11-21.35$ & 435 & 437 & $0 \%$ \\
\hline Pelagic coastal vessels $>21.36 \mathrm{~m}$ & 2,118 & 582 & $-18 \%$ \\
\hline Purse seiners & 2,118 & 1,155 & $-18 \%$ \\
\hline Pelagic trawlers & 344 & 154 & $-55 \%$ \\
\hline Total & 9,877 & 7,966 & $-19 \%$ \\
\hline
\end{tabular}

There is a difference in the registration between 2002 and 2012, which explains why some fleet sections are aggregated in the 2002 numbers. The $<8 \mathrm{~m}$ fleet is also only included in the 2012 numbers, so that needs to be kept in mind when comparing development in the coastal sector. Table 13 clearly demonstrates an interesting trend, showing that employment in the coastal demersal sector has decreased, while employment in the coastal pelagic sector has increased. Estimating the number of coastal fishermen based on the above statistics, however, is not straight forward, since it does not differentiate between full time employment, fisheries as main source of income, secondary source of income or recreational/hobby fishery. With the above in mind, it can however be estimated that coastal fishermen, having fisheries as their main source of income, are around 5,000 in Norway and around 1,500 have fisheries as their secondary source of income. 
The Directorate of Fisheries publishes annually a profitability survey on the Norwegian fishing fleet where operational costs in each fleet category can be seen. A report published in 2013 covers the survey for 2012 (The Norwegian directorate of fisheries, 2013). Looking at the operating margin and return on total assets for the coastal vessels over the past few years, the coastal fleet has been run with low margin and return on total assets has also been relatively low. The pelagic coastal sector has though been the exception, returning healthy profits for some of the years at least, as can be seen in Table 14 (The Norwegian directorate of fisheries, 2013).

Table 14: Operating margin and return on total assets for the different coastal fleets in Norway 2009-2012

\begin{tabular}{|c|c|c|c|c|c|c|c|c|}
\hline \multirow{2}{*}{$\begin{array}{l}\text { Vessel holding license in length group } \\
\text { Year }\end{array}$} & \multicolumn{4}{|c|}{ Operating margin } & \multicolumn{4}{|c|}{ Return on total assets } \\
\hline & 2009 & 2010 & 2011 & 2012 & 2009 & 2010 & 2011 & 2012 \\
\hline Demersal coastal vessels $<11 \mathrm{~m}$ & $0.1 \%$ & $-0.7 \%$ & $6.2 \%$ & $3.9 \%$ & $0.3 \%$ & $-0.5 \%$ & $5 \cdot 5 \%$ & $3.6 \%$ \\
\hline Demersal coastal vessels $11-15 \mathrm{~m}$ & $6.0 \%$ & $7.8 \%$ & $6.6 \%$ & $9.8 \%$ & $4.7 \%$ & $4.9 \%$ & $4.7 \%$ & $6.8 \%$ \\
\hline Demersal coastal vessels $15-21 \mathrm{~m}$ & $5 \cdot 5 \%$ & $6.5 \%$ & $8.0 \%$ & $7 \cdot 3 \%$ & $3.6 \%$ & $3.2 \%$ & $3.9 \%$ & $3.2 \%$ \\
\hline Coastal purse seiners $<11 \mathrm{~m}$ & $16.8 \%$ & $-1.5 \%$ & $14.1 \%$ & $12.5 \%$ & $15.8 \%$ & $-0.9 \%$ & $13.7 \%$ & $3.6 \%$ \\
\hline Coastal purse seiners $11-21 \mathrm{~m}$ & $31.8 \%$ & $12.8 \%$ & $18.5 \%$ & $16.1 \%$ & $20.4 \%$ & $4.9 \%$ & $12.8 \%$ & $7.5 \%$ \\
\hline
\end{tabular}

The table shows that the demersal coastal fleet's return on total assets hardly exceeds the level of interest rates, hence poorly rewarding the owners for the risk involved in the operation. It is therefore hardly worth the effort to continue operation if the owners are presented with the opportunity to sell the assets for a good price. This also explains why there is limited new entry into the sector. It should however be kept in mind that for some of the owners, particularly the older fishermen, the fishery is a way of life and running a boat is a part of having a secure job.

Looking at average revenues, costs and profits for each Norwegian fleet type in 2012 , it is quite clear that the operational environment for demersal coastal vessels is very difficult, and is less likely to return acceptable profits than pelagic coastal vessels. The big profit numbers are however in the larger fleet types, such as purse seiners and cod trawlers, as can be seen in Table 15 (The Norwegian directorate of fisheries, 2013).

Table 15: Average revenues, costs and profits in different Norwegian fleets in 2012

$\begin{array}{lrrrr}\text { Fleet type } & \text { Revenues } & \text { Costs } & \text { Operational results } & \text { Profits before taxes } \\ \text { Demersal coastal vessels <11 m } & 148,783 & 142,931 & 5,852 & 395 \\ \text { Demersal coastal vessels 11-14.9 m } & 382,007 & 344,379 & 37,628 & 24,700 \\ \text { Demersal coastal vessels 15-20.9 m } & 829,797 & 769,539 & 60,259 & -16,262 \\ \text { Conventional "coastal vessels" >21 m } & 1,991,141 & 1,885,552 & 105,589 & -71,064 \\ \text { Conventional deep-sea vessels } & 4,989,127 & 4,743,206 & 245,921 & -58,980 \\ \text { Cod trawlers } & 9,781,106 & 8,638,229 & 1,142,877 & 682,226 \\ \text { Shrimp trawlers } & 425,568 & 397,942 & 27,625 & 7,430 \\ \text { Pelagic coastal vessels <11m } & 188,697 & 165,086 & 23,611 & 24,972 \\ \text { Pelagic coastal vessels 11-21.35 } & 830,845 & 696,692 & 134,153 & 83,162 \\ \text { Pelagic coastal vessels >21.36 m } & 2,973,082 & 2,524,407 & 448,675 & 182,124 \\ \text { Purse seiners } & 6,628,989 & 5,016,888 & 1,612,101 & 1.264,469 \\ \text { Pelagic trawlers } & 2,711,267 & 2,301,471 & 409,795 & 145,394\end{array}$


It is important to keep in mind that these are average numbers, meaning that there are many vessel owners that are running successful businesses in the Norwegian coastal sector. There are, however, also a lot of vessels that are run at a loss. It is therefore likely that the coastal fleet will develop in such a manner that smaller operators will drop out and those capable of investing in quotas, vessels and gear will get a larger share of the fishery.

The Norwegian fisheries management regime has been developed over more than a century. It is based on certain key principles, where some of the main characteristics are based on local exploitation of the fish resources, as well as the common policy that recognises that the fisheries sector is an important contributor to the settlement in coastal areas (OECD, 2006). A strong coastal culture has therefore been developed and implemented into the management system, which favours the coastal sector in a number of ways. The main objective of the fisheries policy is to maximise profits through an economically efficient use of the resources, but also to ensure socioeconomic optimisation with respect to the total gain for the communities, within the limits of sustainable use of the resources.

Suggestions on reformation of the structural- and regulation politics aimed at the different segments of the fishing fleet have been presented as white papers to Parliament (Stortinget) four times since 1992 (Norwegian Ministry of Fisheries, 1992), (Norwegian Ministry of Fisheries, 2003), (Norwegian Ministry of Fisheries, 2007), (Norwegian Ministry of Fisheries, 2013). This comprehensive process has confirmed and reinforced the policy results over the past two decades. As a result, access to the Norwegian common marine resources is restricted and the number of fishing vessels and fishermen have been significantly reduced. These are regarded by the authorities as the most important measures to simultaneously rebuild stocks and increase the productivity in the sector.

Management decisions have often been highly impacted by what is commonly referred to as a "social contract" (samfunnskontrakt). This "contract" is a general understanding that the fisheries sector has social responsibilities that are often more important than economic efficiency. The sector is obligated to keep communities running. This is, for example, highlighted in management decisions where certain fleet types and communities are favoured in one way or another. Requirements for preservation of jobs in coastal communities have been attached to quota allocations, which has been debated considerably in recent years. This "social contract" has therefore benefitted the coastal sector in a number of ways, but is now under political scrutiny, a process that may result in changes in the near future that could be of importance for the coastal sector (Holm \& Henriksen, 2014).

\subsection{Challenges and opportunities}

The main strengths of the coastal sector are that they are fishing from extremely strong stocks, particularly when it comes to the cod, haddock, herring and mackerel stocks. The sector has a positive image, which is supported by strong marketing through the Norwegian Seafood council and other similar supporting agencies. An important 
strength for the coastal fishery is that during parts of the year when the Barents Sea cod is spawning and feeding close to the coast, from January to May, it is easy and inexpensive to get good catches. This means that efforts and operating costs can be minimised. Parts of the coastal sector is modern, well equipped and able to offer stable and well-paid jobs. An important strength of both the coastal sector and rural areas is that the country as a whole is willing to support them, and have for the past decades entered a "social contract" to make sure that coastal communities and the coastal sector can survive.

The main weakness of the coastal sector is the lack of renewal in parts of the sector. A huge proportion of the fleet are small and old and with quotas too small for full-time employment. This part of the fleet has wages hardly competitive with many other sectors. Many coastal communities face problems with a diminishing population, where young people are moving to larger cities for education and a professional career.

There are opportunities for the Norwegian coastal sector in benefitting from strong stocks and a positive image, where marketing of the coastal catches could be an option. The Norwegians have successfully marketed "skrei" in such a manner that it should be possible to do something similar with coastal catches. There are also opportunities in the tourism industry, as there is a large number of tourists coming to northern-Norway to see the fishing villages and the coastal vessels. Some are recreational fishermen that want to experience angling on coastal vessels. While this is an opportunity for many coastal communities, parts of the coastal fleet consider the scale of recreational fisheries to be a threat to their livelihood.

The main threat to many of the coastal villages dependent upon fishing as a source of income, is that more efficient fisheries, consolidation of quotas and automated production on land will lead to fewer jobs. This runs parallel to the overall trend of people moving away from smaller towns to larger cities. Educational opportunities and carriers for educated people (women in particular) are primarily restricted to larger cities. Another threat is that as part of the coastal sector is not returning significant returns on investment, there are other similar industries paying higher wages and there is little recruitment amongst fishermen, it is likely that changes will have to be made in the form of consolidation of quotas, where the number of vessels are reduced to facilitate optimisation in the form of economies of scale. Finally, there is a threat that the "social contract" (samfunnskontrakt) will not be renewed, as the public and the politicians are becoming sceptical on whether it is wise to spread quotas on too many smaller boats in an attempt to keep all small coastal communities alive. 



\section{Denmark}

The definition of a coastal vessel is variable in Denmark. The upper limit used to be 17 meters, but the government recently started a new "protected scheme" which is aimed at boats under 15 meters in length. But despite governmental support to the sector in recent years, the coastal fleet keeps reducing in size and there is almost no renewal amongst fishermen in Denmark.

\subsection{The coastal fleet}

Over the past few decades the rules established for the coastal fleet have applied to vessels under 17 meters that stay out at sea for less than three days i.e. $80 \%$ of fishing trips need to be shorter that three days. Figure 34 shows a typical Danish coastal vessel

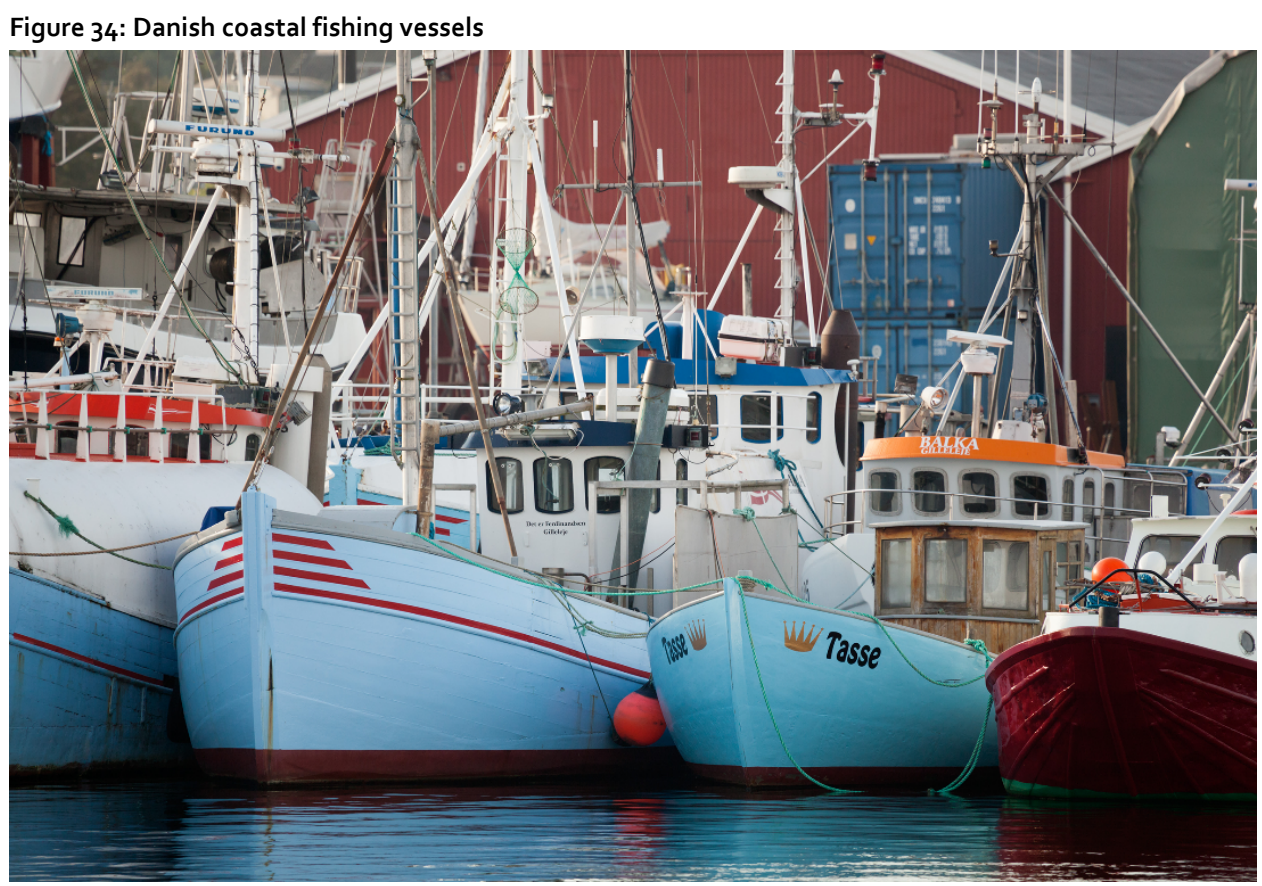

Source: Shutterstock / Matís / steinarba.

The efforts made by the government have however not been sufficient enough to keep the coastal fleet afloat, as the number of fishermen and vessels have reduced significantly over the past two decades. The government has therefore initiated a new "protected scheme" to favour the coastal fleet and the coastal communities. This scheme is divided into two parts i.e. the unlimited order and the time-limited order. 
The protected scheme (the unlimited order) is for vessels under 15 meters. To be part of the protected coastal fishing scheme, fishermen must permanently bind the registered quota's total quota shares and capacity ( $k W$ and BT) in the scheme. This means that the fishermen commit to selling only quotas and capacity to another fisherman in the protected scheme. In order to gain access to its coastal fishery supplement, the following criteria must be met: $80 \%$ of the fishing trips must be 2 days or less and at least $70 \%$ of the vessel's annual quantities of each quota in the preceding calendar year must be landed with the vessel concerned. The vessel may not transfer annual quotas to vessels not registered with the Unlimited Fishing Scheme.

For the open order (the time-limited order), the same rules apply as previously existed for the coastal fisheries scheme. The scheme is for vessels with a maximum length of 17 meters. The vessel owner decides which quotas are registered for the scheme. In order to gain access to a coastal fishery supplement, the following conditions must be met: $80 \%$ of the fishing trips must be 2 days or less and at least $70 \%$ of the vessel's annual quantities of each quota registered for the vessel must be landed with the vessel concerned. The vessel may not transfer quotas to vessels not registered with the coastal fisheries. By entering the coastal fishing system, additional allocations of quotas are granted, where the following TAC have been reserved for this fleet sector:

- $22.4 \%$ of cod in the North Sea

- $30.8 \%$ of cod in the Kattegat

- $47.7 \%$ of cod in the Skagerrak

- $58.1 \%$ of cod in the Baltic Sea and Belts, ICES subdivisions 22-24

- $58.1 \%$ of cod in the Baltic Sea, ICES subdivisions 25-32 (EU waters)

- $44.0 \%$ of heavy in the Skagerrak, Kattegat and the Baltic Sea and the Belts

- $21.3 \%$ of tongue in the North Sea (EU waters)

- $40.0 \%$ of plaice in the Baltic Sea and the Belts

- $25.9 \%$ of plaice in Kattegat

- $22.0 \%$ of plaice in the Skagerrak

There are just over 300 vessels that are eligible for the coastal system, but only about half of them have entered the system.

There are almost 2,300 vessels registered in the Danish fleet, of which 1,800 are vessels below 10 meters that are primarily vessels. In 2016 commercial fishing vessels were less than 580 , with 340 belonging to the coastal fleet. The number of vessels in the coastal sector have decreased significantly since the turn of the century, as can be seen in Figure 35 (Statistics Denmark, 2017). 
Figure 35: Number of fishing vessels in the Danish fleet 2000-2016 according to length

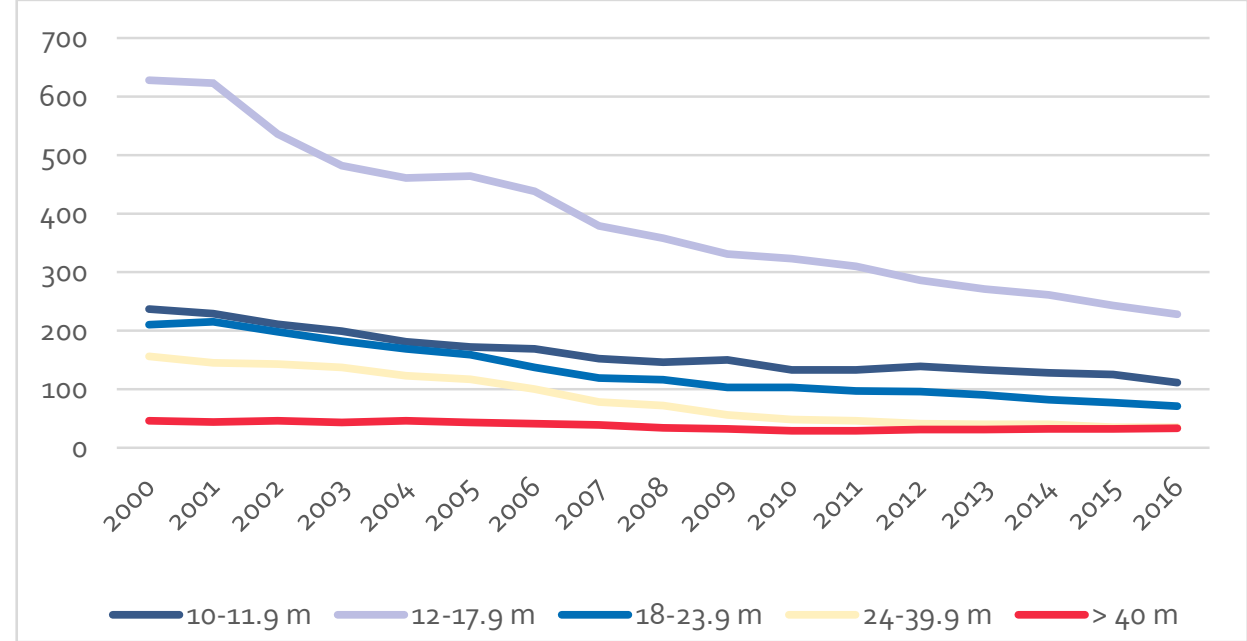

The number of coastal vessels has therefore decreased by $60 \%$ since 2000 . Coastal vessels use primarily gillnets, bottom trawls and pelagic trawls as fishing gear. There are almost 1,200 full time fishermen in the Danish fishing fleet, of which $44 \%$ are working on vessels under 18 meters and $18 \%$ working within the coastal fishing system.

\subsection{Catches and catch values}

The total landings of the Danish fleet in 2015 amounted 920 thousand tonnes, valued at EUR 477 million. The coastal fleet i.e. vessels below 18 meters, accounted for $8 \%$ of the catch volume ( 77 thousand tonnes) and $20 \%$ of the value (EUR 94 million). The distribution of the coastal catches and values according to vessel size are shown in Figure 36 (Statistics Denmark, 2017).

\section{Figure 36: Value of coastal catches in 2015 according to vessel size}

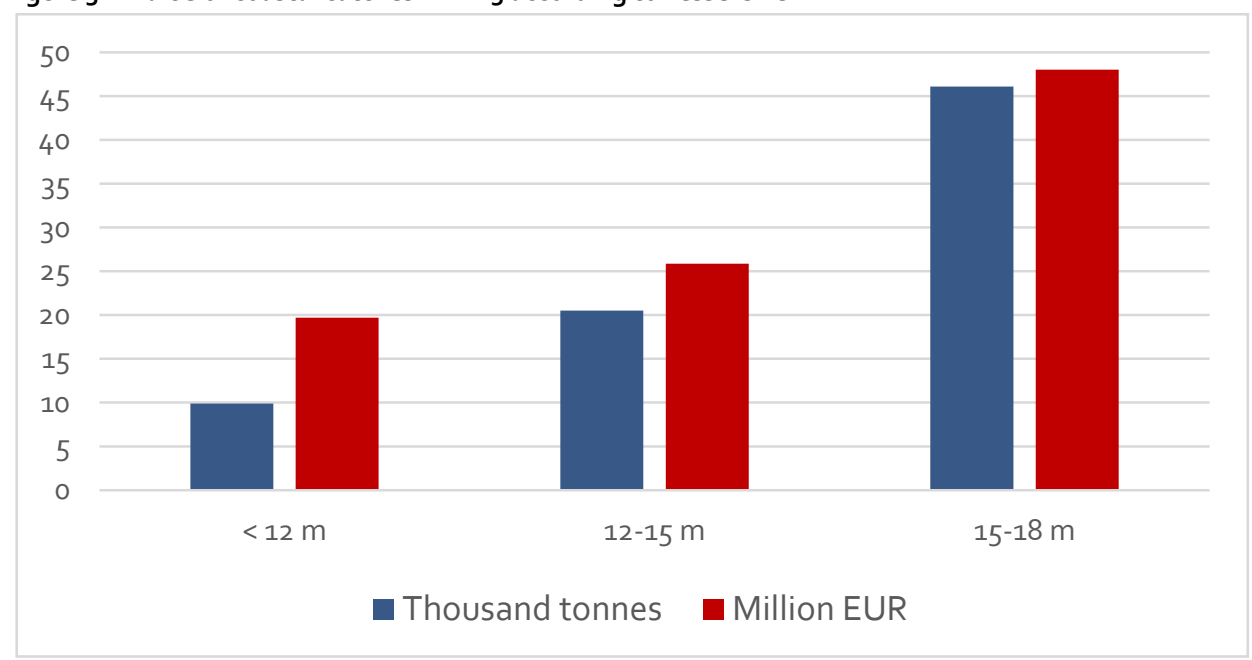


Atlantic cod is the most important species, representing $23 \%$ of the value, followed by crustaceans, molluscs, Nephrops and plaice. Almost half of the catches are industrial fish, which are not going for human consumption.

Numerous research studies have shown that the Danish coastal fleet is struggling because of low income and negative returns (Nielsen, et al., 2013) (Arbejdsgruppe om kystfiskeri, 2013) (Nielsen, et al., 2017). As a result, there has been low recruitment among coastal fishermen because young people do not see any future in entering the sector.

It is also becoming more and more difficult for coastal vessels to reach good fishing grounds, as important stocks keep migrating from traditional inshore grounds. This is particularly observed in the cod and place fishery, where most of the fishery which used to be close to shore has moved further out at sea, as shown in Figure 37 and Figure 38.

Figure 37: The cod fishing has moved from historic fishing grounds (red) to new fishing grounds (green) further out at sea

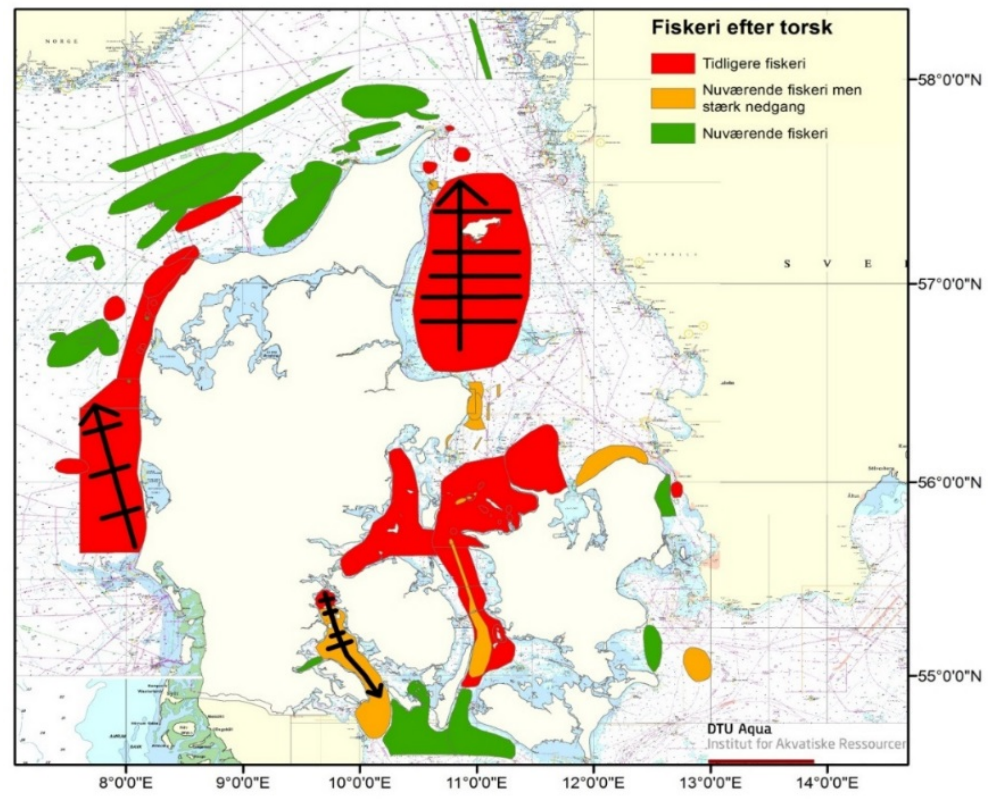

Source: DTU aqua 
Figure 38: Place fishing has also moved from historic fishing grounds (red) to new fishing grounds (green) further out at sea

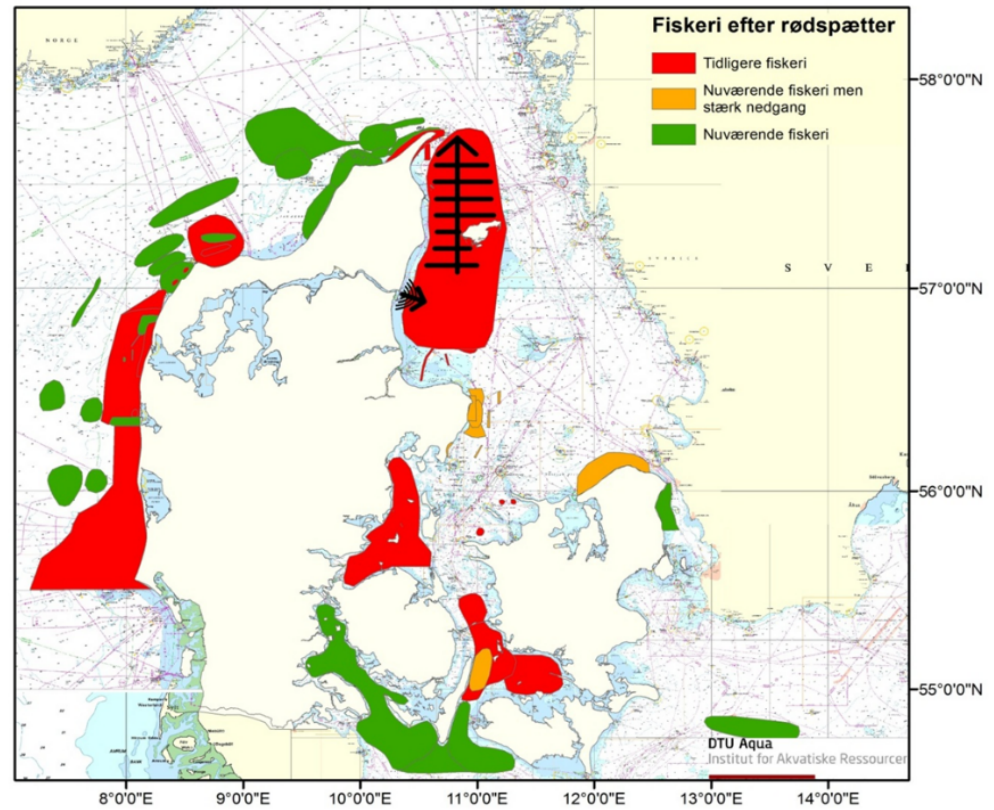

In addition, the coastal fleet is now competing with growing seal population and a very large stock of the great Cormorant. Both of these competitors are protected, so the fishermen have few options to react to this treat. In some cases, there is no use casting gillnets anywhere, as the seals will just eat everything they catch.

The coastal fleet is subjected to a landing obligation that is currently being implemented within the common fisheries policy of the EU. It is difficult to estimate its impact on the coastal sector at this stage, but it is likely that it will have negative effect on the fleet. Under the landing obligation, fishermen are obligated to land all catches and count them against quota. This means that low value catches, some of which may not have any market value, will have to be landed. It also means that small fish (fish below Minimum Conservation Reference Size) will have to be landed, but cannot be used for direct human consumption. Finally, it means that once the quota has been completed for one species all fishing will have to be suspended (choke species).

\subsection{Socioeconomic effects}

There is a political willingness to favour the coastal sector in Denmark, in order to maintain smaller harbours around the country (Nielsen, et al., 2013) (Arbejdsgruppe om kystfiskeri, 2013). This entails that harbours have an attraction beyond the fishing activities, such as providing sense of identity for the fishing villages and as an attraction for tourists. The coastal sector has also a romantic image which makes it "politically correct" to try to preserve it. But the fact is though that there is a large number of 
harbours in Denmark that do not have enough income to cover costs, which is why large number of harbours have been closed down in recent years, meaning that there are no commercially caught fish being landed there anymore and the only purpose of the harbours is to store yachts and recreational boats. Shows where the commercial harbours in Denmark are located and how much share in the total landings they have (Nielsen, et al., 2013).

Figure 39: Harbours with commercial landings in Denmark

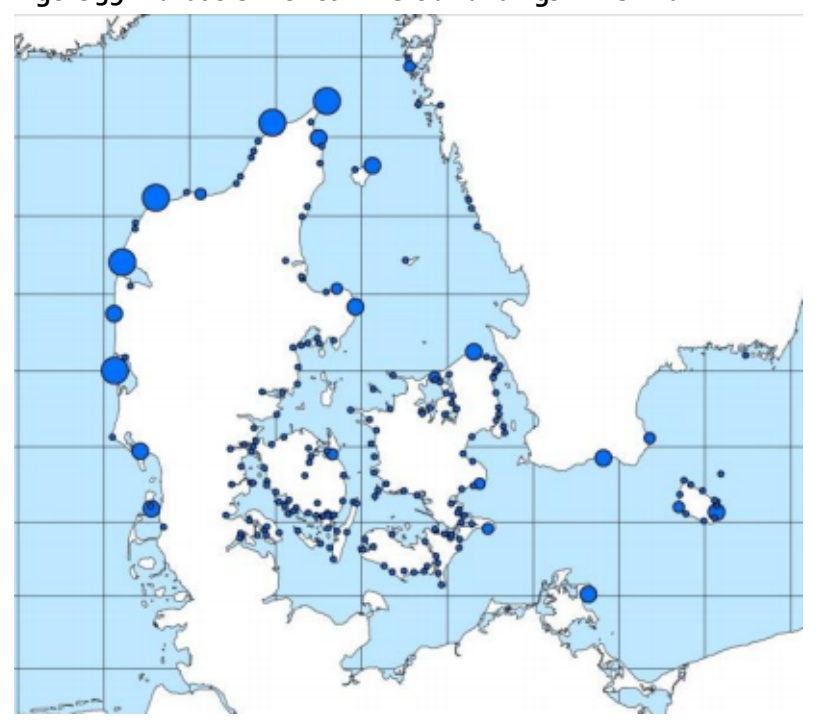

Some coastal fisheries businesses are also competing with other industries for space in the harbours, either for industrial purposes or just for housing, as real estate prices for residential housing in harbour areas have been rising. It is highly likely that this trend of reducing coastal sector will continue, as consolidation will increase where small coastal boats are bought up by larger companies.

Coastal fisheries and coastal fishermen in Denmark have generally a positive image, but it is a very small sector that has limited impact on regional development or employment on national scale. The total population of Denmark is around 5.7 million and the labour market is around 2.8 million, of which coastal fishermen account for $0.02 \%$. Coastal fishermen are therefore a small lobby group that struggles to have its voice heard. The importance of the sector for regional development is also marginal, for more or less the same reasons. The traditional fishing villages do not depend as much on the coastal sector as before, and most of the inhabitants are now working in sectors that have little or nothing to do with fisheries.

\subsection{Challenges and opportunities}

The biggest strength of the coastal fishery in Denmark is its positive image among the nation, as most Danes want to have a thriving small-scale sector so that the small harbours can be full of life. The coastal sector is therefore important for tourist- and 
entertainment purposes. From marketing point of view the coastal sector has a competitive advantage to the industrial fisheries sector, as some consumers favour the concept of small-scale fishing above other alternatives. Finally, one of the strengths of the coastal sector is that it allows opportunity for new entry i.e. fishermen that want to start their own business can do so in the coastal fishery; whilst initial investment costs in other fisheries is much too high for regular fishermen.

The main strength of the fishing villages today is that they are much more diversified than before, and are not depending as much on fisheries as before. Tourism, summer houses, Airbnb and residential housing for people that are trying to get away from the stress of the larger cities is a big strength that can be taken advantage off.

The biggest weaknesses of the coastal fishery and the small fishing villages are that the demersal stocks are small and moving further from shore, salaries are not competitive with other similar sectors, and growing populations of seal and cormorant are making it almost impossible to operate near shore.

There are opportunities for new entry in the coastal sector and better marketing, where favourable characteristics of the fishery could be highlighted, which might provide a competitive advantage and as a result make it more economically feasible to operate within the sector. There are also opportunities in expanding on the image of the sector so that the tourism industry can be better connected to the coastal sector, as is partly happening in some of the other Nordic countries.

The main opportunities for the fishing villages are based on diversification, as they become less dependent on fisheries. Tourist fishing or fishing for tourists represents an opportunity. There are also growing populations that want to live outside larger cities and many highly educated people are actually interested in living in small communities.

The two biggest threats for the coastal sector is that there is basically no new entry of young fishermen into the sector. Wages and income are low so there is not much investment in the fleet and harbour areas dedicated for small-scale fishermen are being reorganised for housing or other industries. The landing obligation that is currently being implemented within the EU fleet represents a threat, which is a little bit of an unknown factor at this stage. A big threat for the fishing villages is that they will become tourist and summer areas, where most of the housing is only used part time. This means that during parts of the year the villages become "ghost towns" and there will not be sufficient need for infrastructure such as schools, kindergartens healthcare etc. in those villages. 



\section{Sweden}

The definition for a coastal fishing vessel in Sweden is the same as in the EU, which is a fishing boat that is less than 12 meters in length. There are about 1,100 coastal vessels left in the country, as they have reduced in number by more than $30 \%$ since the year 2000. Figure 40 shows typical Swedish coastal vessels.

Figure 40: Swedish coastal vessels
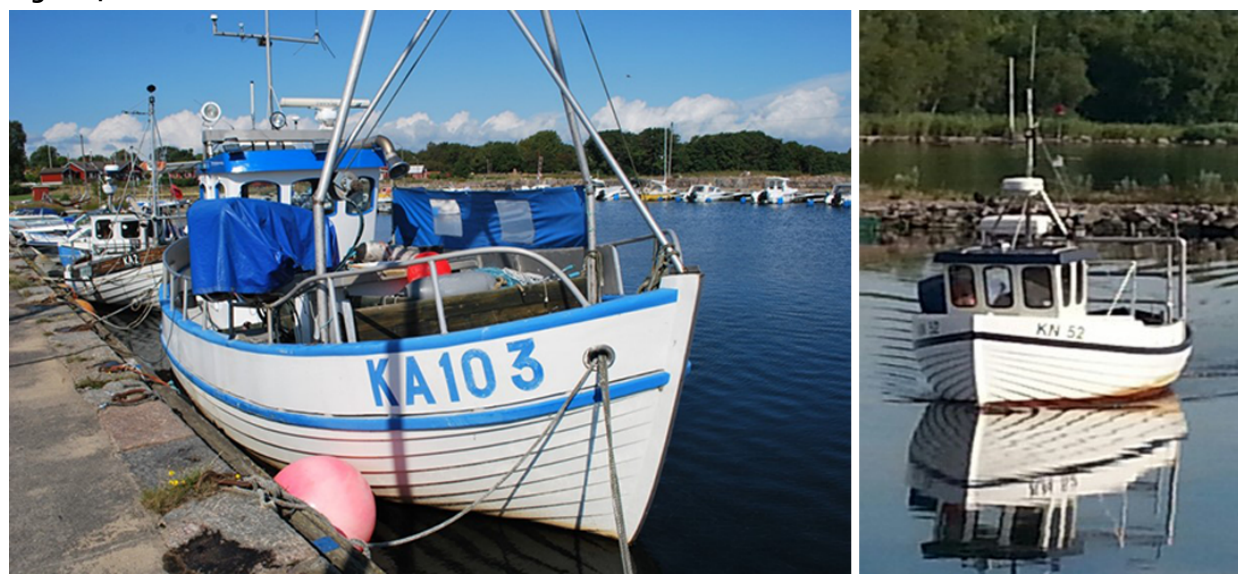

Source: Bengt Larson.

Swedish fishermen have also significantly reduced in numbers, as commercial fishermen have been reduced by more than $1 / 3$ in the last 20 years; and the number of coastal fishermen have declined even more. The main fishing grounds for the coastal sector are in in the Baltic sea, Skagerrak and Kattegat, where the most important stocks have been struggling in recent years.

\subsection{The coastal fleet}

There are 1,277 vessels in the Swedish fishing fleet today, of which 1,114 (87\%) can be defined as coastal vessels. Majority of these are however recreational vessels under 8 meters, so the commercial coastal fleet does therefore only include about 400 vessels, as shown on Figure 41 (Eurostat, 2017). 
Figure 41: The Swedish fishing fleet according to length

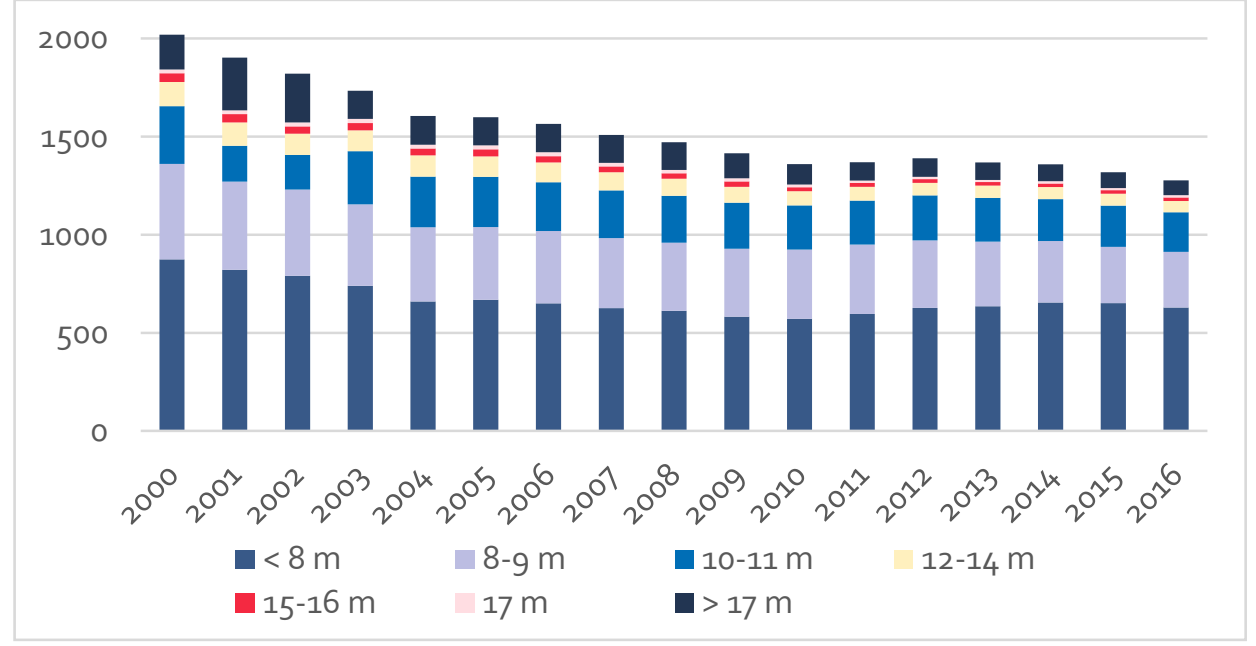

Many of the fishing vessels that are between 8 and 12 meters are however not operated on commercial basis or only operated part of the year. The importance of the coastal sector in job creation has therefore been reducing.

The number of fishermen in Sweden have been in decline over the past few decades, and those that remain are becoming older. In 2013 there were only 1,464 licenced fishermen in Sweden, of which $65 \%$ were over 50 years old, as shown in Figure 42 (Siren, 2014).

Figure 42: The number of licenced Swedish fishermen 1995-2013

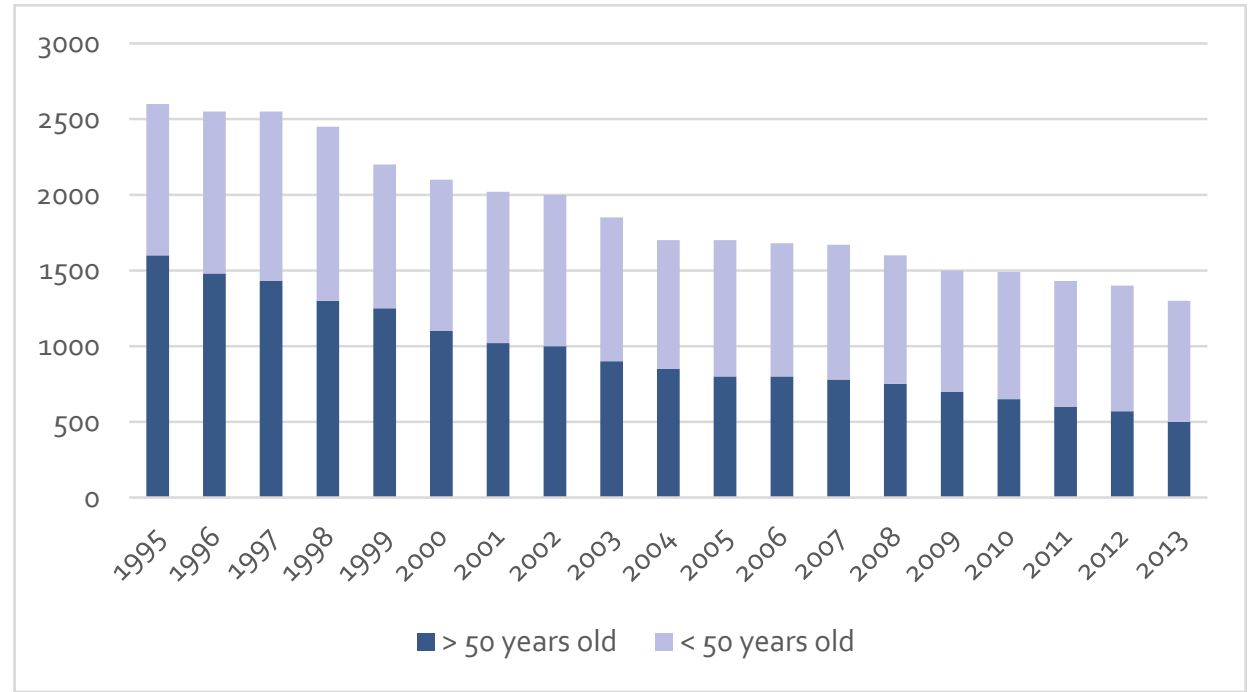

The trend has continued and in 2015 the number of licensed fishermen had reduced down to 1,274 (SVT, 2017). The number of coastal fishermen has reduced even more, as for example fishermen in the east of Sweden fishing in the Baltic Sea, which has traditionally been well represented by the coastal fleet, has reduced by over $50 \%$. 


\subsection{Catches and catch values}

Total catches of the Swedish fleet are around 200 thousand tonnes a year, of which less than 5 thousand tonnes (2\%) are coming from the coastal fleet, as shown on Figure 43 (Havogvatten, 2017).

Figure 43: Total landings of the Swedish fleet and the coastal sector 2001-2016

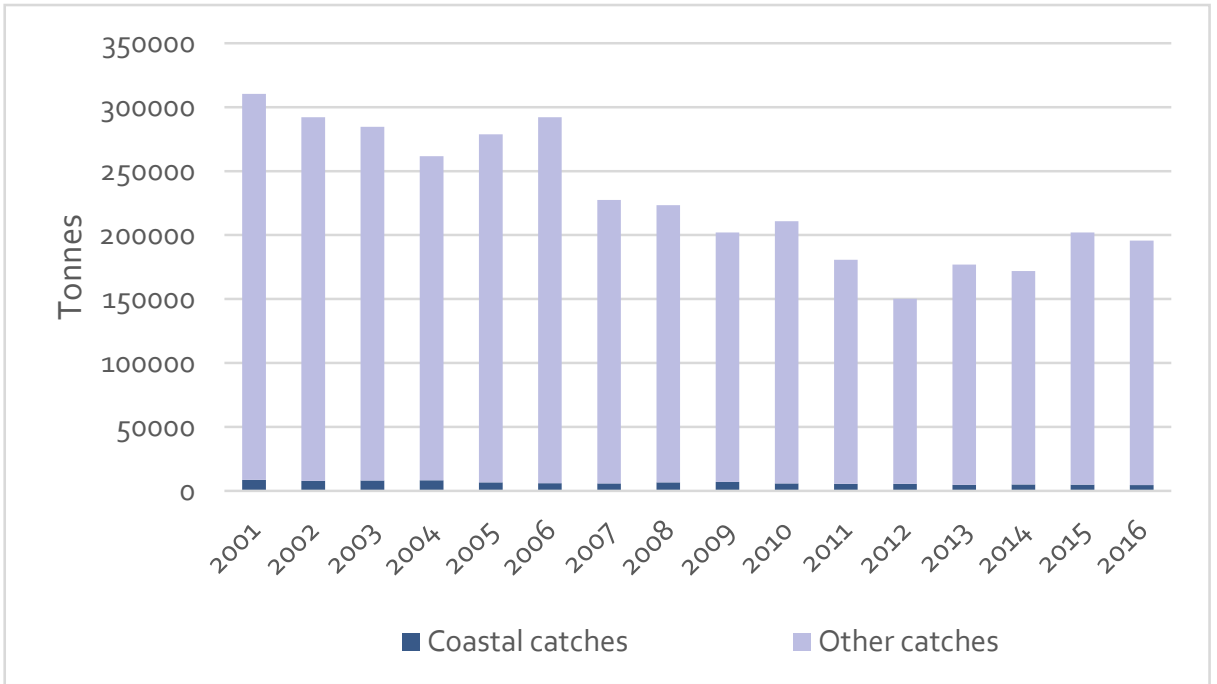

The catches of the coastal fleet have decreased by almost $50 \%$ in the past 20 years, going from 8,500 tonnes down to 4,500 tonnes, as shown in Figure 44 (Havogvatten, 2017). The most important species are cod, herring, Nephrops and salmon, which account for $80 \%$ of the catches.

Figure 44: Catches of the coastal fleet in Sweden by main species 2001-2016

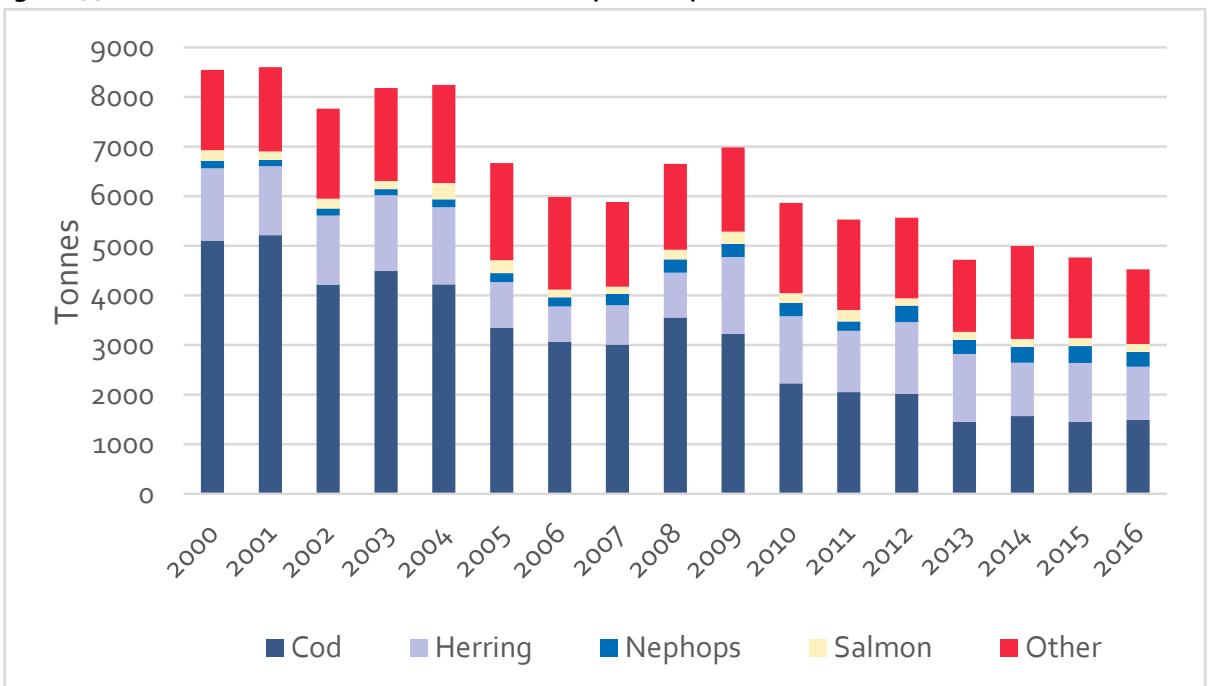


The mainstay of the catches of the Swedish fleet consist of pelagic species such as herring, sprat and sandeel that are almost solely caught by large purse seiners. These three species accounted for $90 \%$ of the total catches in 2016 and $45 \%$ of the landing value. The total landing value of the Swedish fleet has been relatively stable over the past two decades, fluctuating between SEK 900-1,200 million. In 2016 the total landing value was just about SEK 1 billion a year (EUR 100 million). The total landing value of the Swedish fleet by main species is shown in Figure 45 (Havogvatten, 2017).

Figure 45: Landing value of the Swedish fleet by main species 2001-2016

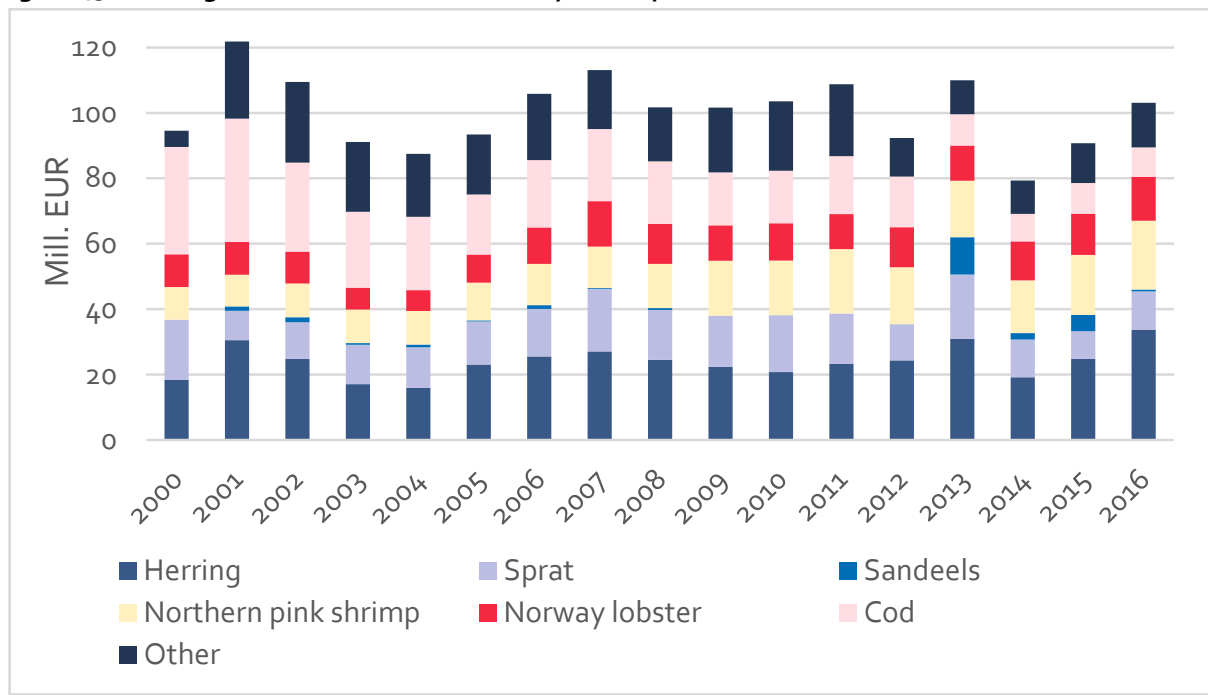

The total landing value of the coastal fleet is though only marginal within the total landings value of the Swedish sector as a whole.

The coastal fleet is subjected to a landing obligation that is currently being implemented within the common fisheries policy of the EU. It is difficult to estimate its impact on the coastal sector at this stage, but it is though likely that it will have negative effect on the fleet. Under the landing obligation, fishermen are obligated to land all catches and count them against quota. This means that low value catches, some of which may not have any market value, will have to be landed. It also means that small fish (fish below Minimum Conservation Reference Size) will have to be landed, but cannot be used for direct human consumption. Finally, it means that once the quota has been completed for one species all fishing will have to be suspended (choke species).

\subsection{Socioeconomic effects}

The coastal sector has traditionally been important in some small coastal communities, particularly in the East coast of Sweden. This has however changed a lot in recent decades and the sector has today relatively little impact on the smaller communities. 
Some coastal fisheries businesses in Sweden are now having to compete with other industries for space in the harbours, either for industrial purposes or just for housing, as real estate prices for residential housing in harbour areas have been rising. The coastal fleet has therefore almost been completely pushed out of some harbours in Sweden.

The image of the coastal sector in Sweden is very positive. The Swedish population is very environmentally thinking and they realise that coastal vessels have much lower environmental impact than the industrial fleet. The Swedish consumers are therefore willing to favour the local coastal fleet and are ready to pay a premium for sustainably sourced fish. Following up on that the coastal fishermen in Sweden have launched a marketing strategy, where people and small businesses (such as restaurants) can buy fish directly from the fisherman through the webpage www.fiskonline.se.

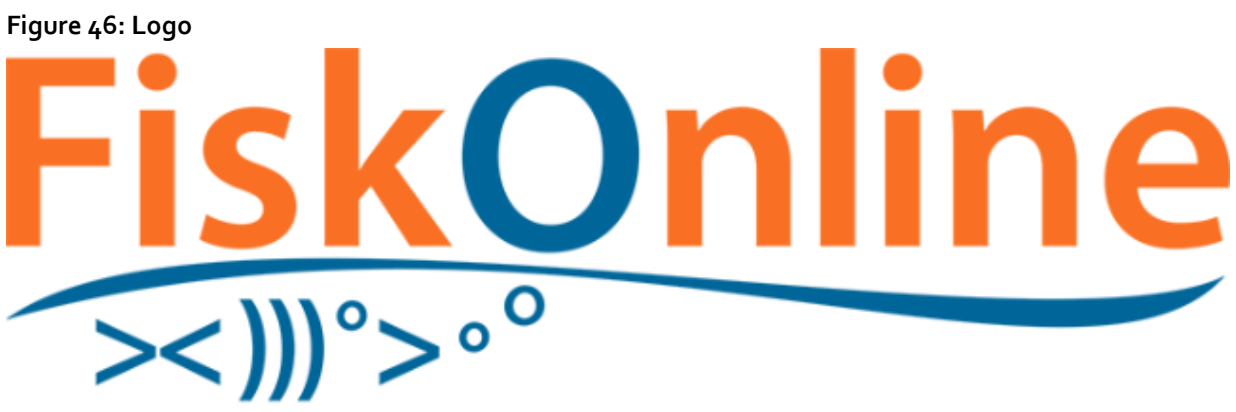

The positive image of the coastal fleet and how important it is for the harbours as an attraction for tourists has been discussed in some municipalities. The fact that this seems to be a dying industry, in some harbours at least, has resulted in speculations that maybe it could be an option to hire actors to pretend to be fishermen, so that the harbours will at least look busy (Ottosson, 2014).

The coastal fleet in Sweden today consists of relatively few vessels and the number coastal fishermen is also decreasing. There is little renewal amongst the fishermen, so the ones still in operation are majorly over the age of 50. The value of the landings is low and the impact on the communities are decreasing. The importance of the coastal fleet for regional development is therefore not nearly as significant as 20-30 years ago.

\subsection{Challenges and opportunities}

The biggest strength of the coastal fishery in Sweden is its positive image among the nation, as most Swedes want to have a thriving small-scale sector so that the small harbours can be full of life and so they can have access to locally caught sustainable seafood. The coastal sector is therefore important for tourist- and entertainment purposes. From marketing point of view the coastal sector has a competitive advantage to the industrial fisheries sectors, as some consumers favour the concept of small-scale fishing above other alternatives. The Fiskonline initiative is a good example on how 
coastal fishermen can separate themselves on the market and highlight the favourable characteristics of their products. Finally, one of the strengths of the coastal sector is that it allows opportunity for new entry i.e. fishermen that want to start their own business can do so in the coastal fishery; whilst initial investment costs in other fisheries is much too high for regular fishermen. The main strength of the fishing villages today is that they are much more diversified than before, and are not depending as much on fisheries as before. Tourism, summer houses, Airbnb and residential housing for people that are trying to get away from the stress of the larger cities is a big strength that can be taken advantage off.

The biggest weaknesses of the coastal fishery and the small fishing villages are that the wages in the sector are low, in comparison with other similar industries. There is little renewal amongst fishermen, as young people do not seem to be interested in the sector.

There are opportunities for new entry in the coastal sector and better marketing, where favourable characteristics of the fishery could be highlighted even further, which might provide a competitive advantage and as a result make it more economically feasible to operate within the sector. There are also opportunities in expanding on the image of the sector so that the tourism industry can be better connected to the coastal sector, as is partly happening in some of the other Nordic countries.

The main opportunities for the fishing villages are based on diversification, as they become less dependent on fisheries. Tourist fishing or fishing for tourists represents an opportunity. There are also growing populations that want to live outside larger cities and many highly educated people are actually interested in living in small communities.

The biggest threats for the coastal sector are that there is basically no new entry of young fishermen into the sector and the wages are too low. The income is too low to justify investment in the fleet and the harbours. The harbour areas dedicated for smallscale fishermen are also being reorganised for housing or other industries, which limits the potentials that the coastal sector has. The landing obligation that is currently being implemented within the EU fleet also represents a threat, which is a little bit of an unknown factor at this stage. 


\section{Newfoundland \& Labrador}

The coastal fleet operating around Newfoundland and Labrador is variable with boats ranging from under 6 meters and up to 15-27 meter vessels. The coastal fleet is more commonly known as the inshore owner-operator fleet where the owners of each vessel operate the ship themselves with the main target catches being crab and other shellfish. The coastal fleet sells its fish to onshore processing companies, who process fish in more than 80 plants across the province. Since the 1979 Fleet Separation Policy, processing companies have been forbidden from acquiring inshore fishing licenses, thus requiring the companies to compete with each other for the catches landed by the coastal fleet.

Fish prices for harvesters are negotiated on an annual basis for various species between the harvester's union, the FFAW (The Fish, Food and Allied Workers Union), and the companies. The union and companies negotiate minimum prices, which is often augmented through wharf competition between the different companies. The coastal fleet has most of the landing volume and value with $60 \%$ and $54 \%$ in 2013 , respectively. In 2016 , the coastal fleet had $67 \%$ of the landed volume and $60 \%$ of the landed value. A net decrease in the number of fishing vessels and processing plant has been seen within the sector, contributing to more consolidation. Furthermore, large fluctuations in catches on an intra annual basis mean that some factories focusing on only one sector might have to close when no catches are being brought to shore. There is hope for an increase in the cod stock since its downfall in 1992, but large investments in infrastructure and operating facilities are needed if that will be the case.

\subsection{The coastal fleet}

As of 31 December 2013, there were 6,958 coastal vessels ( $<89$ feet/27 meters) registered in $\mathrm{NL}$, of which 4,769 reported landings (DFO, 2013). The current regulation requires Federal registration of "all small non-pleasure vessels powered by an engine of 10 horsepower ( $7.5 \mathrm{kw})$ or more." This is a relatively recent change in regulation, but prior to 2008, Canada required registration of vessels exceeding 15 RT and registration of vessels under 15 RT was voluntary. Canadian fleets are responding to this new registration; however, the current data underrepresents the actual fishing effort of the coastal fleet. Canadian fishing vessels are also required to register with DFO (Fisheries and Oceans Canada) Licensing to receive their Vessel Registration Number, a number unique to fishing vessels and different from the vessel's Official Number provided through Federal registration. On account of this, there might be some vessels under 15 RT missing from the list. 
The coastal fleet is highly variable and includes vessels ranging from less than $1 \mathrm{RT}$ up to $150 \mathrm{RT}$, but most are in the range of $11-15 \mathrm{RT}$ and $70 \%$ are less than 9 meters ( 30 feet) in length, as can be seen in Figure 47 (Decker \& Manuel, 2014).

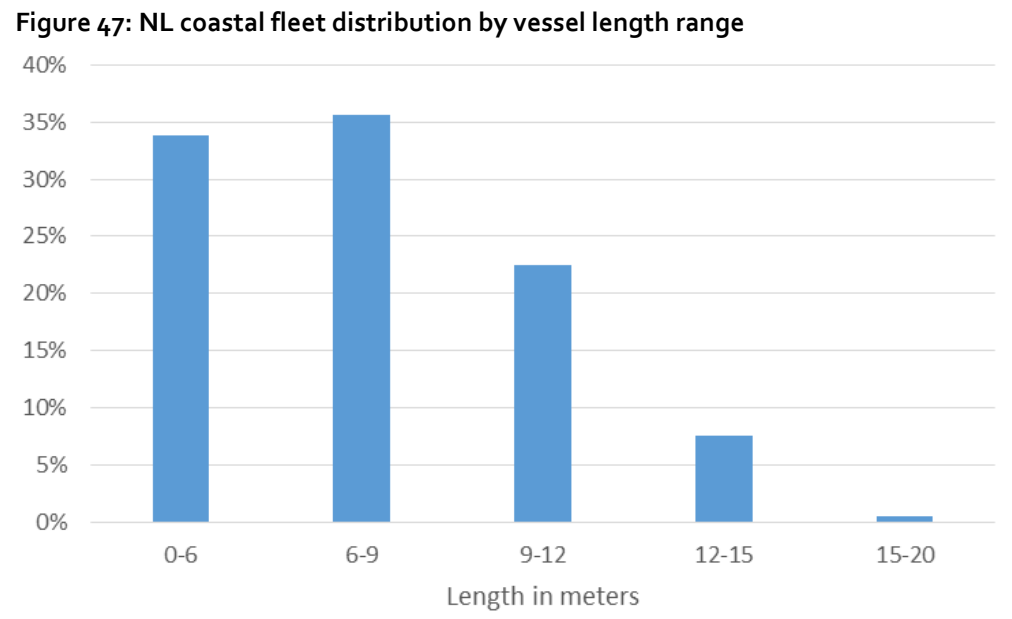

The vessels are primarily geared towards shellfish, i.e. snow crab, shrimp, lobster and whelk. The mainstay of investments in the fleet since the collapse of the cod stock in 1992 have been in the shellfish fleet. However, since 2014 there have been strong signs of a return for groundfish and groundfish quotas for the coastal fleet have more than doubled in recent years. As groundfish recovers there will be a need for large scale investment in the fleet.

Current Canadian fishing policies place specific requirements on how a fishing enterprise is owned and operated. Known as the "owner-operator", the owner of an enterprise must personally fish his or her allocation of fish. It also places a requirement of residency in the region in which quota allocation is held. Owner-operator was enacted to prevent corporate control of fishing licenses, to end resource rent, and to ensure that licensed fish harvesters in the coastal fleet are the primary beneficiaries of the adjacent resource.

The Owner-Operator and Fleet Separation policies are pillars of the coastal economies in NL. These policies allowed for the development of a prosperous shellfish fishery and the harvesters engaged in that fishery now form the backbone of the rural middle class in NL.

\subsection{Catches and catch values}

$\mathrm{NL}$ coastal vessels landed 171 thousand tonnes of catches valued at 240 million EUR in 2013 (DFO, 2014). This amounts to $60 \%$ of total landing volume in NL and $54 \%$ of total landing value in that year. Shellfish, such as lobster, shrimp and crab account for $60 \%$ of the volume and $86 \%$ of the value, where crab alone represents over $61 \%$ of the total value. The coastal fleet is broken into three separate groups when reporting catches, 
i.e. 0-34 ft. (0-10.5 m) inshore fleet, 35-64 ft. (10.5-20 m) nearshore fleet, and 65-89 ft. $(20-27 \mathrm{~m})$ mid-shore fleet. The inshore fleet accounts for around $20 \%$ of both volume and value, but the mainstay of the catches is caught by the larger vessels in the nearshore fleet, as shown in Table 16 (DFO, 2014).

Table 16: Landing volume and value of the NL coastal fleet in 2013

\begin{tabular}{|c|c|c|c|c|c|c|}
\hline \multirow{2}{*}{$\begin{array}{l}\text { Fleet type } \\
\text { Species }\end{array}$} & \multicolumn{2}{|c|}{ Inshore vessels 0-35 ft. } & \multicolumn{2}{|c|}{ Nearshore vessels $35-64 \mathrm{ft}$. } & \multicolumn{2}{|c|}{ Coastal vessels total } \\
\hline & Volume (MT) & $\begin{array}{r}\text { Value } \\
\text { (mill. EUR) }\end{array}$ & Volume (MT) & $\begin{array}{r}\text { Value } \\
\text { (mill. EUR) }\end{array}$ & Volume (MT) & $\begin{array}{r}\text { Value } \\
\text { (mill. EUR) }\end{array}$ \\
\hline Cod & 6,175 & 4.1 & 1,603 & 1.1 & 7,778 & 5.2 \\
\hline Halibut & 266 & 1.6 & 331 & 2.0 & 597 & 3.5 \\
\hline Turbot/Greenland halibut & 140 & 0.3 & 3,973 & 8.2 & 4,113 & 8.5 \\
\hline Other Groundfish & 436 & 0.2 & 941 & 0.5 & 1,377 & 0.7 \\
\hline Herring, Atlantic & 3,100 & 0.6 & 13,628 & 2.6 & 16,728 & 3.2 \\
\hline Mackerel & 49 & 0.0 & 3,607 & 1.4 & 3,656 & 1.4 \\
\hline Capelin & 10,019 & 1.4 & 17,827 & 2.5 & 27,846 & 3.8 \\
\hline Other Pelagics & 57 & 0.2 & 30 & 0.1 & 87 & 0.3 \\
\hline Scallop & 23 & 0.0 & 1,050 & 1.7 & 1,073 & 1.7 \\
\hline Whelks & 623 & 0.6 & 4,122 & 4.0 & 4,744 & 4.6 \\
\hline Other Molluscs & 817 & 1.0 & 243 & 0.3 & 1,060 & 1.3 \\
\hline Lobster & 2,183 & 12.0 & 18 & 01 & 2,200 & 12.1 \\
\hline Shrimp, Pandalus Borealis & 0 & 0.0 & 49,615 & $45 \cdot 5$ & 49,615 & $45 \cdot 5$ \\
\hline Crab, Queen/Snow & 9,880 & 29.5 & 39,400 & 117.6 & 49,279 & 147.1 \\
\hline Other Crustacean & 79 & 0.0 & 702 & 0.4 & 780 & 0.4 \\
\hline Total & 33,847 & 51.4 & 137,086 & 187.9 & 170,933 & $239 \cdot 3$ \\
\hline
\end{tabular}

The most important species for the inshore fleet are cod, lobster and crab, representing $90 \%$ of the value in 2013 , as shown in Figure 48 . The larger nearshore vessels are a bit more diverse, but over $90 \%$ of their catch value also come from only three species, crab, shrimp and turbot.

Figure 48: Landing values by species of the two NL coastal fleets in 2013 (mill. EUR)

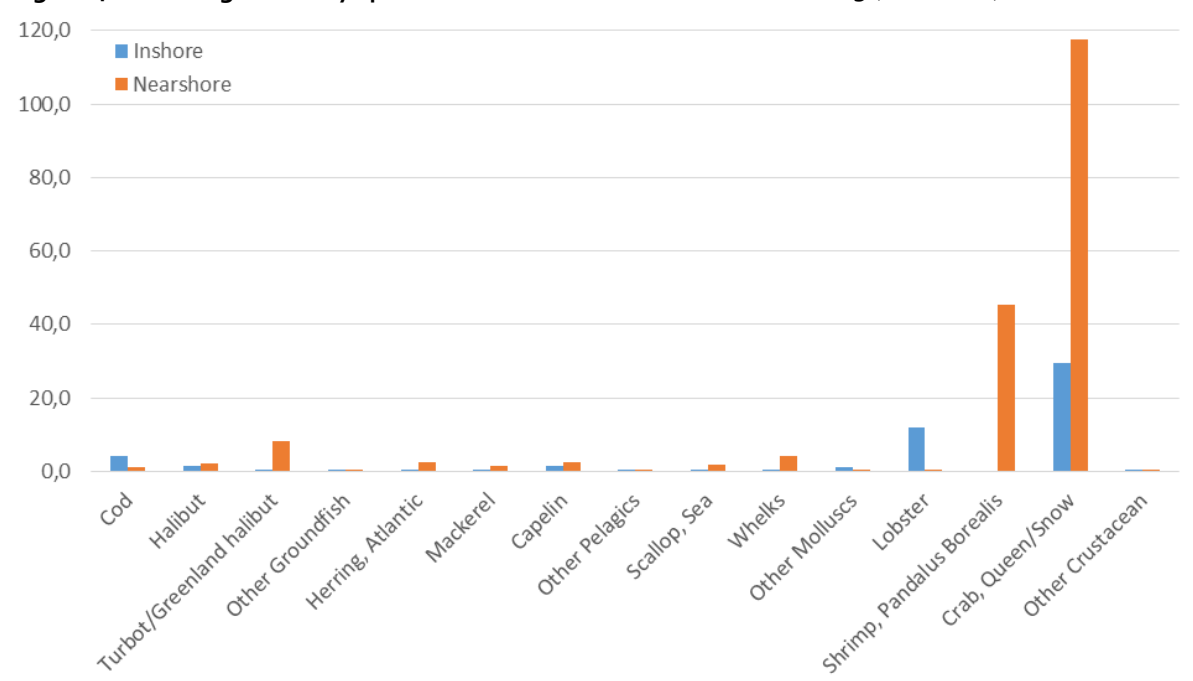


Since the forum that gave rise to this report, there have been significant developments in the cod fishery in NL that need to be included. For the past decade, the cod stocks off the coast of NL have shown strong and steady growth after more than a decade of relative stagnation. In 2016, the growth of the stock was substantial enough to support a meaningful increase in cod quota to harvesters. Whereas for several years the overall quota had been set at approximately 5,000 MT, in 2016 approximately 11,000 MT were landed.

As part of this new cod fishery, harvesters have moved away from the individual quota (IQ) system introduced with shellfish, which is blamed for increasing the cost of licenses, increasing harvester debt, and increasing the intrusion of corporate interests in the coastal fishery. Under the new cod fishery, each participating harvester is given a weekly quota and harvesters can only catch their own weekly quota. Quotas that are not caught do not carry over from week-to-week. The weekly quota approach ensures that the benefits of the resource stay with active harvesters, which relates the value of the license to the harvesting effort and not the corresponding quota.

Under the weekly quota system, quotas are being increased incrementally so that the new cod fishery can be sustainably built. Weekly quotas allow for harvesters to focus on quality and to develop quality-based systems that can work when weekly quotas inevitably increase. The weekly quota system is also allowing the processing sector to be rebuilt and allows time for investment in new technologies.

\subsection{Socioeconomic effects}

The Department of Fisheries and Oceans (DFO) is responsible for management of the fish stocks in Canadian waters while the Government of NL regulates the onshore processing sector. A major objective of the Canadian fisheries policy is to ensure that allocation of fishery resources is based on conservation, with access to fish stocks for harvesting based upon the closeness to the resource, the relative dependence of coastal communities and the various fleet sectors upon a given resource, as well as economic efficiency and fleet mobility. The coastal fleet has therefore a strong position within the NL fisheries sector. DFO allocates quotas for each stock within each fisheries management division, as shown in Figure 49 (DFO, 2014). The quotas within each division are then distributed amongst the fleet sectors. For many of the demersal stocks, 3 the mainstay of the quota is allocated to the coastal fleet, as shown in Figure 50. 
Figure 49: Fisheries management divisions in NL

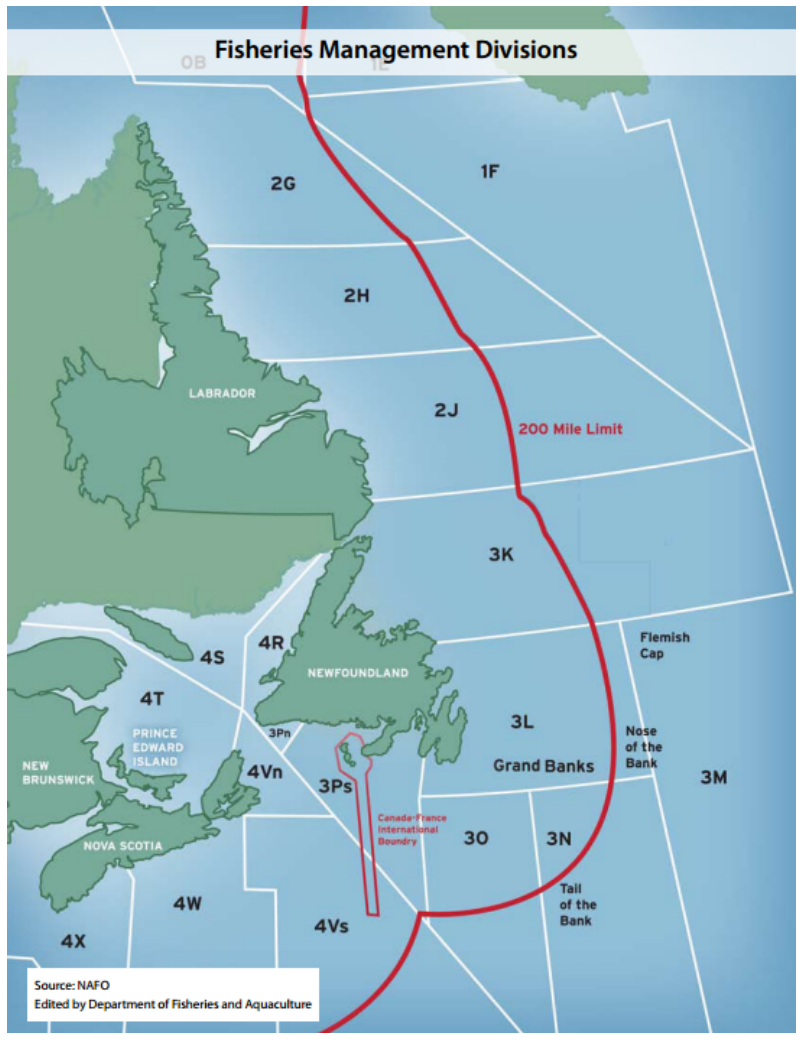

To be eligible to apply for licences and quotas in NL the vessel owners must be defined as professional fish harvesters. Professionalization recognizes the special skills and experience required to become a professional in the fishing sector. Professionalization can either be granted by "grandfathering" ${ }^{6}$ or by qualifying for professionalization.

With NL being Canada's third largest exporter of seafood and fish and the most valuable species being snow/queen crab, shrimp and Greenland halibut, the coastal sector fishing for those species has an important role regarding exporting values. The export values in 2011 were at EUR 370, 226 and 48 million, respectively for the species mentioned.

${ }^{6}$ Grandfathering is the granting of professional status for those who have a longer-term attachment to fishing, while new entrants must qualify through training and experience for professionalization. 
Figure 50: Coastal fleets percentage of total NL landings of demersal species in 2012

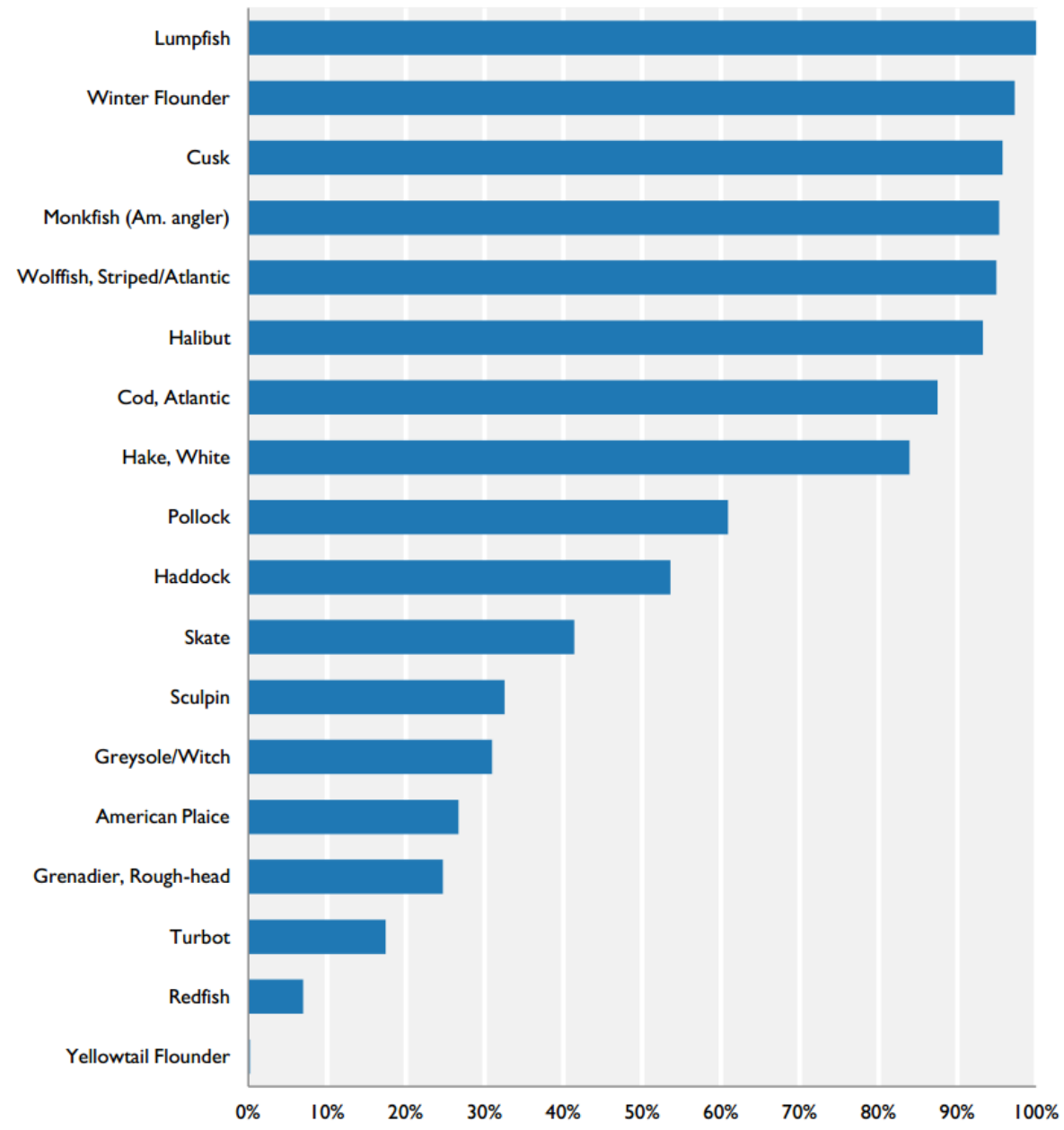

Coastal fisheries and processing of coastal catch are extremely important for rural development in NL. In 2013 there were 9,500 people working in the coastal catch sector and 8,400 in the processing sector in NL (Decker \& Manuel, 2014), which represents $7.1 \%$ of the workforce (Newfoundland \& Labrador statistics agency, 2014). Estimated market value of the products was EUR 640 million, which amounts to $2.5 \%$ of NL GDP (Statistics Canada, 2014). There has been a significant decrease in the number of coastal vessels and processing plants in recent years, where the number of vessels has decreased by $60 \%$ and processing plants by $48 \%$, as can be seen in Table 17 (Decker \& Manuel, 2014). 


\begin{tabular}{lrrr} 
& 1998 & 2013 & Decrease \\
Vessels & 11,200 & 4,500 & $60 \%$ \\
Plants & 214 & 111 & $48 \%$ \\
Harvesters & 16,500 & 9,500 & $42 \%$ \\
Plant workers & 21,000 & 8,400 & $60 \%$ \\
\hline
\end{tabular}

At the same time, there has been a lack of renewal within the sectors, which means that the average age of harvesters and processors has been increasing. Between the years 1990 and 2010 , the number of fish harvesters over the age of 55 increased by $35 \%$, while at the same time, the number of fish harvesters under the age of 25 decreased by almost $80 \%$. A positive twist relating to this development is that the average annual income has increased significantly. The same development pattern has been seen in the processing sector, as shown in Table 18 (Decker \& Manuel, 2014).

Table 18: Changes is age distribution of NL fish harvesters and plant workers between 1990 and 2010

\begin{tabular}{lrr|r|rrrrrrr} 
& \multicolumn{2}{c}{ Age $<25$} & \multicolumn{3}{c}{ Age $>55$} & \multicolumn{3}{c}{ Average annual income } \\
& 1990 & 2010 & Change & 1990 & 2010 & Change & 1990 & 2010 & Change \\
& 2,200 & 500 & $-77 \%$ & 2,000 & 2,700 & $35 \%$ & 14,572 & 32,050 & $120 \%$ \\
Fish harvesters & 5,370 & 1,340 & $-75 \%$ & 1,500 & 2,600 & $73 \%$ & 16,140 & 26,840 & $66 \%$ \\
\hline
\end{tabular}

Some of the fisheries and related processing are highly seasonal, such as the crab fishery. This means that processing facilities, vessels and labour must be available for relatively short period of time and will then either have to close or find alternative means of income and work. There are 99 communities in NL that had processing plants relying on coastal catches in 2013, with 111 plants and 86 companies.

In 2013, the total number of coastal fishermen in NL was 9,500, but this number had then seen a decrease of $40 \%$ from 1998 (Decker \& Manuel, 2014). With little recruitment in the coastal sector, the average age of the fishermen has also been increasing along with a net decrease in the number of vessels. However, the net income of the fleet operating now has increased considerably on average, indicating a near complete shift to the more valuable shellfish fisheries, though there are some enterprises that focus heavily on pelagics, such as capelin, herring and mackerel.

The crab and shellfish fisheries account for majority of the income of these coastal demersal fisheries and in line with that fact, most of the revenues and investments have been made in those sectors. However, it is the hope of local governing bodies that a return of species such as cod is on the cards, reaching similar levels as were seen prior to 1992 . The cod fishery has the potential to be highly profitable if expectations of bigger cod stocks come true, but investments in vessels, processing and infrastructure will be needed. In line with what has been described, the evolution of the regional development has been showing similar trends as other countries such as Faroe Islands and Greenland, where the younger generations are not making investments and 
recruiting themselves into the fisheries due to financial reasons and rather seek education or jobs in larger cities away from smaller villages and settlements.

\subsection{Challenges and opportunities}

The NL coastal sector draws its main strength from a strong crab and shellfish industry, which provides a good income for the sector. Vessels are in most cases operated by their owners, thus facilitating corporate competition for raw material and preventing corporate vertical integration. It adds to the strengths of the sector that crab and shrimp are amongst the most valuable export products in Canada. A major strength is that the cod stock is rebounding and new approaches to the coastal cod fishery are focused on quality, value, and market development. The recently enacted Canada-European Union Comprehensive Economic Trade Agreement (CETA) should also provide added opportunities for processors to increase the value of exports, which will benefit both the harvesting and processing sectors. It can also be listed as a strength that strong collective bargaining legislation in Canada sets mandatory arbitration to allow for fisheries to avoid labour disruption.

The NL coastal sector also has a number of major weaknesses; such as high initial investment cost; low renewal of workers in the sector and large fluctuations in catches. The average age of coastal fishermen is increasing with little renewal of the fleet. The number of fishermen in the coastal industry under the age of 25 has seen a reduction of $80 \%$ over a span of 20 year, from 1990 to 2010 . The fishery is also characterised by large fluctuations in catching volumes of some key species, which means that processing facilities must either specialize in several species or resort to closing their operation over some time. It can also be described as a weakness that there has been a significant re-arranging of the fishery since the 1990s, which has made the fishery stronger; but plant closures have been an unfortunate part of that change.

There are significant opportunities in the NL coastal sector. The expected rise in the cod stock will undoubtedly present opportunities for the coastal fleet, with new investments providing jobs both in setup, processing and fishing. The increase in profits of the operational fishermen left in the coastal sector might be used to help younger fishermen getting into the industry in the form of loans or through the "grandfathering" approach; a renewal within the coastal workers is desperately needed.

The most obvious threats that the sector is facing is the further ageing of the fleet and its personnel resulting in high average age and stagnation. It is clear that considerable investments will be needed if and when the cod stock comes back, and it is a major threat that the funding will not be available for that. And finally, there is a threat in a further decrease in processing facilities, due to inactivity over low profit periods as many of the fisheries are highly seasonal. 


\section{Discussions and conclusions}

Small coastal communities in North Atlantic are being faced with number of challenges, as they struggle to maintain their population, provide job opportunities, service to their inhabitants and provide the necessary infrastructure so that young people decide to make a future in these communities. Most of these communities rely heavily on the coastal fishing fleet for survival, where the fleet is in one way or another the backbone of employment in the areas. Most of the other jobs in these communities are directly or indirectly servicing the catching or the processing sector.

The development all across the world has been that people are moving away from small rural communities to urban areas, where there are more opportunities for education, better access to healthcare, entertainment and services that improve quality of life. At the same time authorities try to support regional development to maintain settlement across the countries. The coastal fishing fleet is a key component of the economy within these coastal communities, which is why authorities in most of the Nordic countries have put in place initiatives that are meant to favour the coastal fleet. These initiatives do however not seem to be working as planned, as the number of vessels and fishermen keep reducing, along with inhabitants in the communities. The trend in migration from rural communities to larger cities does not seem to be easily reversed.

This report has reviewed the coastal sectors in seven Nordic countries, which include almost 20 thousand coastal vessels that are catching close to 900 thousand tonnes a year, valued at EUR 1.2 billion, as shown in Table 19.

Table 19: The number of coastal vessels in the Nordic countries, along with their total catches and catch values

\begin{tabular}{lrrrr} 
Country & Vessels & Catches (tonnes) & Value (Mill. EUR) & Average pr. Vessel \\
\hline Faroe Islands & & & & \\
Greenland & 426 & 4,417 & 7,5 & 17,606 \\
Iceland & 1,816 & 124,000 & 165,0 & 90,859 \\
Norway & 1,284 & 94,000 & 152,0 & 118,380 \\
Denmark & 5,583 & 400,000 & 550,0 & 98,513 \\
Sweden & 2,134 & 76,000 & 7,0 & 37,020 \\
NL & 1,114 & 4,500 & $-N a-$ & $-N a-$ \\
Total & 6,958 & 171,000 & 240,0 & 34,493 \\
& 19,315 & 873,917 & 1,194 & 61,791 \\
\hline
\end{tabular}

The fleets are though highly variable in each of the countries, ranging from very basic traditional dinghies catching few kilos of fish each year to highly technical industrial vessels with annual catches exceeding 1,000 tonnes. The sector as a whole in all of the countries is run at a loss or with extremely small profits on average, but in some of the countries (Iceland and Norway in particular) there are segments that are returning healthy profits. The common weakness of the coastal sector is that it is not competitive 
with other fleet sectors when it comes to wages. In addition, it has become extremely expensive to start out fresh as a vessel owner in the industry - but traditionally this sector used to provide fishermen with a "way in" to become vessel owners. The general trend is that vessels are becoming larger and better equipped, meaning that fewer vessels are needed to catch the same amount of fish. This has the effect that companies merge or smaller operators are bought up by the larger ones. Fishing rights are aggregated by those that have access to capital, which is primarily based on economics of scale.

It is in fact the larger and more technologically advanced vessels that are returning profits and paying competitive wages, which is why this development may be inevitable and possibly the only realistic way of ensuring that coastal fisheries can survive and even thrive. Fewer, better equipped, industrial coastal vessels that provide good stable and high paying jobs, healthy profits for the owners and reliable quality supplies for the processing sector. On the downside, it will mean that the coastal fleet will continue to decrease in number of vessels and number of fishermen; and that new entry will become even more difficult, because of the initial investment needed.

The countries addressed in the report deal with different challenges; and do each have their unique strengths, weaknesses, opportunities and threats. A common strength is that coastal catches have many favourable characteristics that should be able to provide competitive advantage over other fleet sectors. The fish are for the most parts landed on the day of capture, the fishery has very little environmental impact with almost no by-catches, minimum seafloor disturbance and low fuel to catch ratio, the image of the coastal fishery is good which enables for a good "storytelling" through proper marketing. There are therefore opportunities in market differentiation of coastal catches.

There are as well opportunities in all of the countries in moving parts of the coastal fishery into tourism. This has already been happening in some of the countries, where a promising industry is evolving around sea angling, bird watching, whale watching and the whole coastal community way of life. There are even examples of whole villages marketing themselves on that basis.

There are also opportunities for countries or areas such as Newfoundland \& Labrador and Greenland to draw upon the experience in Norway and Iceland, where at least parts of the fleets are quite successful. Both Newfoundland and Greenland are expecting their cod stocks to grow significantly in the next few years, which may provide an opportunity to build up a strong industrial coastal sector. The challenge is that in both countries, the coastal fleet and processing are outdated. The groundfish fishery in Newfoundland in particular has to make large-scale investments in catching and processing sectors, as almost no investments have been made in those sectors since the collapse of the cod stock in the early gos. Knowledge- and technological transfer between successful coastal sectors in the Nordic countries is therefore most certainly the way forward for Newfoundland and Greenland.

The Greenlandic coastal sector has to deal with a unique and difficult challenge when it comes to transportation within the country itself and to foreign markets. Most of the coastal communities are small and relatively isolated. This means that total 
landings in each community are not sufficient to justify large-scale investment in processing facilities; and transportation difficulties between communities hamper that catches can be aggregated in a large centralised processing plants. Sea freight transportation within Greenland and to international harbours is also under a monopoly, where Royal Arctic Line is the only company that is allowed to operate. The mainstay of exports has to go through Royal Arctic Line's transportation hub in Aalborg in Denmark, which limits the potentials in marketing of Greenlandic coastal catches.

The Faroe Islands coastal sector is in the difficult situation that the groundfish stocks around the islands are in a very pore condition. The stocks are therefore not able to support a profitable coastal fishery at the moment. There are though opportunities for a part of the fleet to move into the pelagic sector, for example by fishing mackerel on hooks; which some coastal vessels have been exploring. There are also opportunities within the tourism industry for the coastal fleet and the coastal communities, as tourists are looking for such an experience.

The difficulties that the coastal sectors in Denmark and Sweden are dealing with are quite different from those of the other countries. The coastal fleets in both countries are of little significance for the national economy or for regional development. There are though exceptions in Denmark, where a number of communities are dependent on the coastal sector. The main challenges the coastal fleets in both countries are facing are low profitability, competition with other sectors for use of harbour space, changing distribution of the most important fish stocks and coexistence with protected species such as the great cormorant and seal populations. In addition, the Swedish and the Danish fishery is operating within the EU Common Fisheries Policy, which is implementing a landing obligation. This discard ban obligates fishermen to land all catches, regardless of whether it has any commercial value or not. It also means that fishermen will have to stop fishing when quotas are reached in one species (choke species). This is likely to have significantly impact on the economic returns within the sector.

The Icelandic and the Norwegian coastal fleets are similar in the sense that they include a large number of vessels that are fragmented into extremely different segments. Relatively small part of the fleets in both countries are industrial technologically advanced vessels that account the mainstay of the catches. These vessels represent also the part of the fleet that is returning healthy profits. Then there are a large number of vessels that have limited fishing rights and are struggling to return profits and pay competitive wages. Finally, it is the part of the fleet that includes the largest number of vessels and is bordering on being considered commercial; due to either lack of fishing rights or that the owners are primarily recreational fishermen. Without governmental intervention, it is likely that the industrial and more technologically advanced parts of the coastal sector that are returning profits will grow larger, at the expense of the other fleet segments. This will further reduce the number of vessels and fishermen operating in the coastal fishery. The effects of such a development on the coastal communities is difficult to assess, as on one hand it will support a coastal sector that is competitive with other sectors, but on the other hand it will severely reduce the number of vessels and fishermen. 
There is an important seasonal difference in the catches of the coastal fleets in Iceland and Norway. The mainstay of the catches of the Norwegian fleet are taken during February to May, when the cod stock aggregates on shallower waters of the Norwegian coast to spawn. The Icelandic coastal catches are on the other hand relatively evenly distributed throughout the whole year. This has of course an effect on how the fleet is operated, how the processing is handled, marketing, prices and to a point the quality of the raw material. This has also an effect on the coastal communities, as the importance of the coastal fleet fluctuated depending on time of year.

Coastal fisheries and coastal communities in the Nordic countries are facing challenging times, as the number of coastal vessels and fishermen continue to decrease, along with the number of inhabitants in the communities. Despite governmental attempts to support the sector it appears that the global trend in migration from rural communities to larger cities applies to coastal villages too.

The coastal sector does though have strengths and opportunities which can be taken advantage of to make sure that this fleet sector and the communities can survive. This will though depend on political willingness, investment and cooperation within the sector. 


\section{References}

Agnarsson, S. (2012). Útgerð smábáta og línuívilnun. Reykjavík: Hagfræðistofnun Háskóla Íslands.

Agnarsson, S., Matthiasson, S., \& Giry, F. (2016). Conslolidation and distribution of quota holdings in the Icelandic fisheries. Marine Policy, 263-270.

Arbejdsgruppe om kystfiskeri. (2013). Rapport fra arbejdsgruppe om kystfiskeri. copenhagen: rapport fra arbejdsgruppe om kystfiskeri.

Berthelsen, T. (2017, 02). Coastal fisheries in Greenland. Nuuk: KNAPK.

Bjarnason, P. (2012). Hagsmunir íslenskra sjávarbyggða við endurskoðun fiskveiðistjórnunar. Akureyri: Háskólinn á Akureyri.

Business Line. (2017, September 12). Roknskapir. Retrieved from www.bl.fo: http://www.bl.fo/

Byggðastofnun. (2017). Stöðugreining 2017: Byggðapróun á Íslandi. Sauðárkrókur: Byggðastofnun.

Danielsen, R. (2014). Spatial Access Priority Mapping: A Quantitative GIS Method for Inclusive Marine Spatial Planning. Reykjavík: University of Iceland.

Danish Maritime Authority. (2012). Excel doc. København.

Decker, D., \& Manuel, H. (2014, September 27th). Conference on coastal fisheries and coastal communitites: Newfoundland and Labrador. Retrieved from Coastal fisheries:

http://www.coastalfisheries.net/wp-content/uploads/2014/06/Newfoundland.pdf

DFO. (2013, December 31st). Licences, permits and vessels in Atlantic region. Retrieved from Fisheries and oceans Canada: http://www.dfo-mpo.gc.ca/stats/commercial/licencespermis/licences-permis-atl-eng.htm

DFO. (2014, December 16th). Fish Landings and landed values. Retrieved from Fisheries and Oceans Canada: http://www.nfl.dfo-mpo.gc.ca/NL/Landings-Values

DFO. (2014). Seafood industry year in review 2013. St. John's, NL, Canada: Department of Fisheries and Aquaculture.

Eurostat. (2017, October 2). Fishing fleet by age, length and gross tonnage. Retrieved from www.eurostat.eu: http://ec.europa.eu/eurostat/web/fisheries/data/database

Faroe Marine Research Institute. (2017). Tilmæli um fiskiskapin eftir toski, hýsu og upsa i fiskiárinum 2016-2017. Thorshavn: Faroe Marine Research Institute.

Føroya Skipaskráseting. (2016). Føroya Skipaskráseting. Throshavn: Teyggjan.

Government of Greenland. (2014, May 21st). Order No. 6 on fishing for lumpfish. Executeve Order No. xx. Nuuk, Greenland.

Gregersen, O. (2016, November 10). CEO. (R. Danielsen, Interviewer).

Grétarsson, H., \& Danielsen, R. (2014). The Faroese effort quoat management system. Arctic review on law and politics, 100-122.

Gunnarsdóttir, A. (2009). Orsakir búferlaflutninga kvenna af landsbyggđinni. Reykjavík: Háskóli Íslands.

Hagstova Føroya. (2017a). Faroe Islands in figures. Thorshavn: Hagstova Føroya.

Hagstova Føroya. (2017b, September 6). Útflutningur skiftur á vørubólkar og mánađir (19932017). Retrieved from Hagtalsgrunnur:

http://statbank.hagstova.fo/pxweb/fo/H2/H2_UH_UHo1/uh_ututgr.px/?rxid=57eb45fd-

2d95-40dc-9995-a452c77cfebb 
Hagstova Føroya. (2017c, September 10). Útflutningur av vørum skiftur á høvuðsbólkar og mánaðir (1993-2017). Retrieved from Hagtalsgrunnur:

http://statbank.hagstova.fo/pxweb/fo/H2/H2_UH_UHo1/uh_uthbolk.px/?rxid=2db413b7-

31d4-4540-b97e-daeoa5ao82ge

Havogvatten. (2017, October 6). SwAM's statistical database of catches. Retrieved from

https://havbi.havochbatten.se: https://havbi.havochvatten.se/analytics/saw.dll?PortalPages

Heleniak, T. (2014). Migration in the Arctic. In H. E.-P. L. Heininen, Arctic Yearbook 2014.

Akureyri, Iceland: Northern Research Forum.

Henriksen, E. (2014). Norwegian coastal fisheries. Tromso: Nofima.

Holm, P., \& Henriksen, E. (2014). Mot en ny samfunnskontrakt. Tromsø: UiT.

i Jákupsstovu, S., Cruz, L., Maguire, J.-J., \& Reinert, J. (2007). Effort regulation of the demersal fisheries at the Faroe Islands : a 10-year appraisal. ICES, 730-737.

Icelandic Directorate of Fisheries. (2017, October 10). Kvótastaða 50 stærstu í krókaaflahlutdeild 2017. Retrieved from www. fiskistofa.is:

http://www.fiskistofa.is/media/frettir/Krokaaflahlutdeild_mars_2017_50_staerstu.xlsx

Islandsbanki. (2016). Íslenski sjávarútvegurinn 2016. Reykjavík: Islandsbanki.

Jóhannesson, B. (1998). Breyttir atvinnuhættir og byggðapróun. Sauðárkrókur: Byggðastofnun.

Jóhannesson, S., Árnason, S., \& Sigurðsson, S. (2013). Hagvöxtur landshluta 2007-2011.

Sauðárkrókur: Byggðastofnun.

Knútsson, Ö., Kristófersson, D., \& Gestsson, H. (2012, 9. árg. 2. tbl). Áhrif fiskveiðistjórnunará virðiskeðju íslensks bolfisks. Tímarit um viðskipti og efnahagssmál.

Løkkegaard, J., Andersen, J., Boje, J., Frost, H., \& Hovgård, H. (2004). Rapport om den færøske regulering af fiskeriet: færømodellen. Copenhagen: DTU.

McBean, G. (2004). Arctic climate impact assessment. New york: Cambridge University press.

Newfoundland \& Labrador statistics agency. (2014, January 1). Employment in fishing industry. Retrieved from www.stats.gov.nl.ca:

http://www.stats.gov.nl.ca/Statistics/Labour/PDF/Employment_Fishing_Industry.pdf

Nielsen, M., Asche, F., Bergesen, O., Blomquist, J., Hoff, A., Nielsen, R., ... Waldo, S. (2017).

The myth of the poor fisher: evidence from the Nordic countries. Marine Policy, In press.

Nielsen, M., Larsen, E., Egekvist, J., Gedefaw Adate, T., Nielsen, R., Frost, H., \& Kjærsgaard, J. (2013). Dansk kystfiskeri: Struktur og økonomi. Copenhagen: University of Copenhagen.

Norwegian Directorate of Fisheries. (2017, October 5). Statistikkbank. Retrieved from www.fiskeridir.no: https://www.fiskeridir.no/Statistikk/Statistikkbank

Norwegian Ministry of Fisheries. (1992). Struktur- og reguleringspolitikk overfor fiskeflåten (Strukturmeldingen), St.meld.nr 58 (1991-1992). Oslo: Norwegian Ministry of Fisheries.

Norwegian Ministry of Fisheries. (2003). Strukturtiltak i kystfiskeflåten, St. meld. nr. 20 (20022003). Oslo: Norwegian Ministry of Fisheries.

Norwegian Ministry of Fisheries. (2007). Strukturpolitikk for fiskeflåten, St.meld. nr. 21 (20062007). Oslo: Norwegian Ministry of Fisheries.

Norwegian Ministry of Fisheries. (2013). Verdens fremste sjømatnasjon, St.meld.nr 22. Oslo: Norwegian Ministry of Fisheries.

OECD. (2006). Using market mechanisms to manage fisheries: smoothing the path. Paris: OECD publishing.

Ottosson, C.-A. (2014, September 27). (J. R. Viðarsson, Interviewer).

Pálsson, Ö. (2014). Skýrsla framkvæmdastjóra 2014. Reykjavík: National Association of Small Boat Owners.

Parliament, T. G. (1996, October 31st). Fisheries legislation. Act no. 18. Nuuk, Greenland.

Samgöngustofa. (2017). Skipaskrá yfir íslensk skip og báta 2017. Reykjavík: Samgöngustofa.

Siren. (2014). Swedish fishermen quitting jobs in droves. Stockholm: Siren news agency. 
Statistics Canada. (2014, November 5th). Gross domestic product, expenditure-based, by province and territory. Retrieved from Statistics Canada: http://www.statcan.gc.ca/tablestableaux/sum-som/lo1/csto1/econ15-eng.htm

Statistics Denmark. (2017, September 20). Business sectors. Retrieved from www.statbank.dk: http://www.statbank.dk/statbank5a/default.asp?w=1920

Statistics Greenland. (2014, December 18th). Main employment for permanent residents by time, industry, gender, age, place of residence, place of birth and inventory variable. Retrieved from Grønlands statistisk: http://bank.stat.gl/Dialog/Saveshow.asp

Statistics Greenland. (2014b, October 28th). Total landings of fish and shellfish by time, municipality, species, unit and month. Retrieved from Statistics Greenland:

http://bank.stat.gl/Dialog/varval.asp?ma=FIEoo1\&path=../Database/Greenland/Fisheries\%20a nd\%20Catch/\&lang=1

Statistics Greenland. (2017a). Greenland in figures. Nuuk: Statistics Greenland.

Statistics Greenland. (2017a). Udenrigshandel 2016. Nuuk: Statistics Greenland.

Statistics Greenland. (2017b, October 6). Total landings of fish and shellfish by time, municipality, species, unit and month. Retrieved from Statbank Greenland:

http://bank.stat.gl/pxweb/en/Greenland/Greenland_FI_Fl10/FIXo01.px/?rxid=2a8c698f5b7d-46bf-81af-59bbfo4d6658

Statistics Greenland. (2017b, September 28th). Total landings of fish and shellfish by time, municipality, species, unit and month. Retrieved from Statistics Greenland:

http://bank.stat.gl/Dialog/varval.asp?ma=FIEoo1\&path=../Database/Greenland/Fisheries\%20a nd\%20Catch/\&lang=1

Statistics Iceland. (2017a, October 5). Afli og verđmæti afla eftir kvótaflokkum skipa og heimahöfnum peirra 1992-2016. Retrieved from www.hagstofan.is:

http://px.hagstofa.is/pxis/pxweb/is/Atvinnuvegir/Atvinnuvegir_sjavarutvegur_aflatolur_kv otaflokkar/SJAogo20.px/?rxid=c39c3350-0110-47a1-8139-1aec4d2886b7

Statistics Iceland. (2017b, October 15). Rekstraryfirlit fiskkveiða 1997-2015. Retrieved from www.hagstofan.is:

http://px.hagstofa.is/pxis/pxweb/is/Atvinnuvegir/Atvinnuvegir_sjavarutvegur_afkomasja/SJ

Ao8101.px/?rxid=48boe 755-8788-4f6b-a78d-0058440a81fd

Statistics Iceland. (2017c, October 10). Fjöldi i ađalstarfi eftir atvinnugreinum (bálkar), kyni og búsetu 2008-2016. Retrieved from www.hagstofa.is:

http://px.hagstofa.is/pxis/pxweb/is/Samfelag/Samfelag_vinnumarkadur_3_arstolur/VINo110 5.px/table/tableViewLayout1/?rxid=01336536-8540-4d66-896c-c4db21f7d612

SVT. (2017, February 26). Allt färre yrkesfiskare in Våstsverige. Retrieved from www.svt.se: https://www.svt.se/nyheter/lokalt/vast/allt-farre-yrkesfiskare-i-vastsverige?

The Icelandic Directorate of Fisheries. (2017, January 29th). Landanir eftir skipum, fisktegundum og ástandi 2016. Hafnarfjörður: Fiskistofa. Retrieved from www.fiskistofa.is:

http://www.fiskistofa.is/media/aflatolur/29012013_Afli_e_skipum_fisktegundum_2012.xls

The Norwegian directorate of fisheries. (2004). Lønnsomhetsundersøkelser 2002. Bergen:

Fiskeridirektorated.

The Norwegian directorate of fisheries. (2013). 2012 Profitability survey on the Norwegian fishing fleet. Bergen: Fiskeridirektoratet.

The Norwegian directorate of fisheries. (2014b, December 15th). Fiskeridirektoratets statistikkbank. Retrieved from Fiskeridirektoratet:

http://www. fiskeridir.no/fiskeridirektoratets-statistikkbank

The Norwegian Directorate of Fisheries. (2017, October 1). Norwegian fishing vessels, fishermen and licenses. Retrieved from www. fiskeridir.no:

http://www.fiskeridir.no/english/statistics/norwegian-fisheries/norwegian-fishing-vesselsfishermen-and-licenses

Verðlagsstofa skiptaverðs. (2017, October 10). Fiskverð. Retrieved from www.verðlagsstofa.is: http://www.verdlagsstofa.is/index.php/fiskvere/manaearlegt 
Viðarsson, J., Sigurðardottir, S., \& Sveinpórsdóttir, R. (2016). Employment and salaries in the Icelandic coastal fisheries. Reykjavík: Matís.

Vørn. (2017, October 10). Veiða sambært avreiðingarseðli. Retrieved from www.fve.fo: http://fve.fo/Index.asp?pID=\%7B72587944-A4C8-4ABA-B1 $C_{3}-$

1086708776E1\%7D\&Stat=\%7CVei\%C3\%Boa\%2osamb\%C3\%A6rt\%2oavrei\%C3\%Boingarse\%C 3\%Boli\&URL=http://hagtol.fve.fo/fvehagtoel/fvePortal.exe/ParamsLanding 


\section{Sammenfatning}

Kystfiskeri spiller en afgørende rolle i de nordiske lades marinesektor og fungerer ofte som fundament i mindre kystsamfunds økonomi. Sædvanligvis har fiskefartøjer en stor tilstedeværelse i mindre og fjerntliggende fiskerbyer, der forsyner lokale forarbejdningsvirksomheder med råmateriale. Derfor er kystsektoren yderst vigtig for regionaludviklingen, da den udgør en væsentlig del af de samlede landinger og tilbyder beskæftigelse for et stort antal fiskere, forarbejdningsvirksomheder og andre understøttende industrier. Urbanisering og hurtig teknisk udvikling inden for fiskerisektoren i de sidste par årtier har medført, at mange kystsamfund skal kæmpe for deres overlevelse. Mens kystfiskeriet generelt kæmper med at returnere et overskud, er der også andre udfordringer, som kystsamfundene står over for; som forskellige sociale strukturer, uddannelses- og jobmuligheder og krav til en vis "livskvalitet", der får folk til at overgå fra kystsamfund til større byer.

Denne rapport gennemgår kystsektorer i syv nordiske lande (Færøerne, Grønland, Island, Norge, Danmark, Sverige og Newfoundland), som omfatter næsten 20 tusind kystfartøjer, der fanger op mod goo tusind tons om året, med en værdiansættelse til 1,2 milliarder EUR. Dog er fiskefartøjerne meget variable, og rangerer fra meget grundlæggende traditionelle joller, der fanger få kilo fisk hvert år til stærkt tekniske industrifartøjer med årlige fangster på over 1.000 tons. Samtidig skal de enkelte lande også håndtere forskellige udfordringer; og hver har deres unikke styrker, svagheder, muligheder og trusler, som diskuteres i rapporten. 
Nordic Council of Ministers

Nordens Hus

Ved Stranden 18

DK-1061 Copenhagen $\mathrm{K}$

www.norden.org

\section{NORDIC COASTAL FISHERIES AND COMMUNITIES}

Coastal fisheries play a vital role in the marine sector of the Nordic countries and serves as a backbone of the economy of many smaller coastal communities. The coastal fleets usually have a big presence in smaller, more remote fishing villages, supplying local processing companies with raw material. The coastal sector is therefore highly important for regional development, as it represents a significant part of total landings and offers employment for a large number of fishermen, processors and other supporting industries.

This report reviews the coastal sectors in seven Nordic countries, which include almost 20 thousand coastal vessels that are catching close to 900 thousand tonnes a year, valued at 1.2 billion EUR. The fleets are highly variable and the individual countries do each have their unique strengths, weaknesses, opportunities and threats, which are discussed in the report. 